INSTITUTO DE PESQUISAS ENERGÉTICAS E NUCLEARES

AUTARQUIA ASSOCIADA À UNIVERSIDADE DE SÃO PAULO

\title{
GANHOS AMBIENTAIS E ENERGÉTICOS COM A UTILIZAÇÃO DA BIOMASSA RESIDUAL DE GADO LEITEIRO EM LAGOA DA PRATA- MG
}

FLÁVIO SOARES DE OLIVEIRA

Tese apresentada como parte dos requisitos para obtenção do grau de Mestre em Ciências na área de Tecnologia Nuclear- Materiais

Orientadora:

Dra. Fátima Maria Sequeira de Carvalho

SÃO PAULO 


\section{Dedicatória}

Uma das maiores riquezas de nosso Brasil são os esforçados homens do campo, que geralmente vivem à margem das Universidades e Academias, porém estão sempre buscando com engenho e criatividade sua sobrevivência e fixação no campo. Esta pesquisa foi elaborada pensando nestes valorosos homens e mulheres que se esforçam para que $o$ alimento de nosso dia a dia chegue a nossas mesas e a eles eu dedico este trabalho 
Agradecimentos

Ao Divino Mestre Jesus e à Mãe Santíssima pelo manto de ternura, saúde e disposição para chegar onde estou

Ao Grande Mestre pelo embasamento na doutrina onde o Querer é Poder

À minha família por compreender meu desejo de crescimento profissional

A minha querida amiga e companheira de jornada Manuella pelo amor e carinho em diversos momentos para chegar aonde cheguei

Aos nobres amigos Márcio e Evelina pelo carinho em ceder sua casa para eu morar e ter condições de viver com dignidade em São Paulo

Ao nobre amigo e irmão Edson Hiroshi Seo que me encorajou para pesquisar e contribuir um pouco com a sociedade rural

A querida professora Dra Fátima Maria Sequeira de Carvalho, pelas orientações e diversos auxílios para que esta pesquisa se concretizasse

Ao Professor Jorge de Lucas Jr. pelo apoio nos laboratórios na UNESP de Jaboticabal- SP

Aos fazendeiros proprietários das nove fazendas pesquisadas em Lagoa da Prata-MG pela receptividade e apoio na pesquisa em campo

A CAPES, pela bolsa que foi de grande valia para sobrevivência e manutenção dos estudos 


\title{
GANHOS AMBIENTAIS E ENERGÉTICOS COM A UTILIZAÇÃO DA BIOMASSA RESIDUAL DE GADO LEITEIRO EM LAGOA DA PRATA- MG
}

\author{
Flávio Soares de Oliveira \\ RESUMO
}

O objetivo deste trabalho foi investigar os ganhos ambientais e energéticos com o aproveitamento da biomassa residual de gado leiteiro no município de Lagoa da Prata-MG. Para este estudo realizaram-se trabalhos de campo, tanto para caracterizar a pecuária leiteira no município, como para conhecer os aspectos ambientais da localidade. Para se conseguirem dados de relevância energética e ambiental, visitaram-se nove fazendas da região onde os responsáveis responderam a um questionário. Recolheram-se amostras de resíduos do gado confinado em cada uma delas. Os resultados da pesquisa mostraram uma média de 3 toneladas de geração diária de biomassa residual por propriedade. Constatou-se um consumo médio de energia elétrica de 2.500 $\mathrm{kW} / \mathrm{h}$, pela utilização de uma série de equipamentos energointensivos. Encontrou-se um consumo médio de água de $27 \mathrm{~m}^{3} / \mathrm{dia}$. Realizaram-se análises químicas por Espectrometria de Fluorescência com Raio X nas amostras de resíduos e observaram-se concentrações médias relativamente altas para os elementos $\mathrm{P}, \mathrm{Fe}, \mathrm{S}, \mathrm{Ti}, \mathrm{Mn}, \mathrm{Zn}$ e Na, passíveis de comprometer o meio ambiente local e regional.

Para diagnosticar os ganhos energéticos foi simulada a produção de biogás através de protótipos de biodigestores com as amostras de dejetos obtidas nas fazendas. Os resultados analíticos do biogás através de cromatografia gasosa demonstraram concentrações aproximadas de $70 \%$ de $\mathrm{CH}_{4}$, logo concluiu-se que o biogás obtido possui alto valor energético. Portanto, a utilização dos dejetos do gado leiteiro na produção de biogás, além de resolver o problema dos resíduos, efluentes e diversas outras poluições ambientais, eventualmente geradas pela atividade na região, poderá trazer auto-suficiência energética às propriedades locais. 


\title{
PROFIT ENVIRONMENTAL AND ENERGY USE OF BIOMASS WITH RESIDUAL OF DAIRY CATTLE IN THE LAGOA DA PRATA-MG
}

\author{
Flávio Soares de Oliveira
}

\begin{abstract}
The objective of this study was to investigate the environmental and energetic gains with the use of residual biomass from dairy cattle in the city of Lagoa da Prata, MG. It was conducted a field work for this study, to know both the dairy farming in the city and the region environmental aspects. In order to achieve relevant energy and environmental data, nine farms in the region were visited, and a questionnaire was answered by those responsible for the farms. Residual biomass samples from dairy cattle were collected from each farm. The survey results showed an average of 3 tons of daily residual biomass per property. Average energy consumption in all visited farms was estimated to be 2,500 $\mathrm{kW} / \mathrm{h}$ by the use of high energy consuming equipments. We found a $27 \mathrm{~m}^{3} / \mathrm{day}$ average consumption of water. X-ray Fluorescence analysis of the biomass samples showed that relatively high concentrations of $\mathrm{P}, \mathrm{Fe}, \mathrm{S}, \mathrm{Ti}, \mathrm{Mn}, \mathrm{Zn}$ and $\mathrm{Na}$ elements, which could compromise the local environment. To diagnose the energy gain was simulated to produce biogas digesters through prototypes with samples of manure collected in the farms. The analytical results of the biogas by gas chromatography showed concentrations of approximately $70 \%$ of $\mathrm{CH}_{4}$, soon concluded that biogas has high energy value obtained. The results indicated that the use of dairy cattle manure in the production of biogas, besides solving the problem of waste, effluents and various other environmental pollutants eventually generated on site, can bring energetic self-sufficiency for the local properties.
\end{abstract}


RESÍDUO NADA MAIS É QUE MATÉRIA PRIMA MAL APROVEITADA Provérbio Chinês 


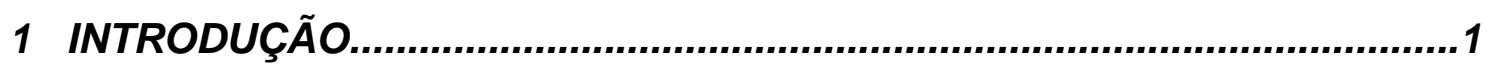

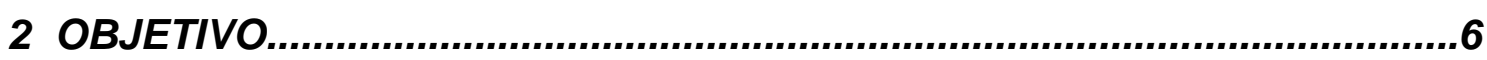

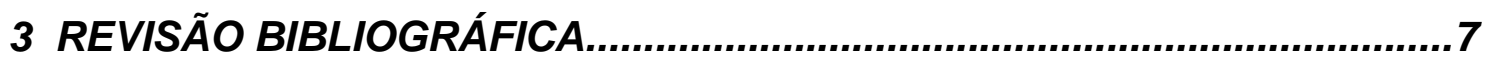

3.1 Características do agronegócio leiteiro................................................

3.2 Resíduos agropecuários e suas implicações ambientais........................9

3.2.1 Poluição do solo e da água..............................................................11

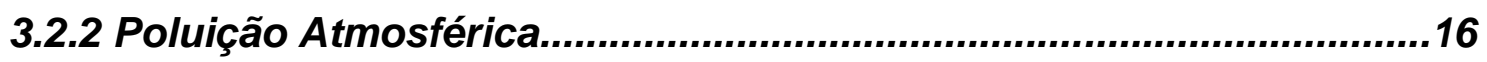

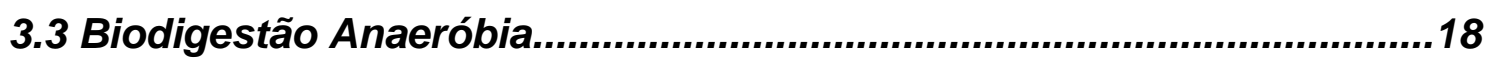

3.4 Aspectos históricos sobre o biogás....................................................19

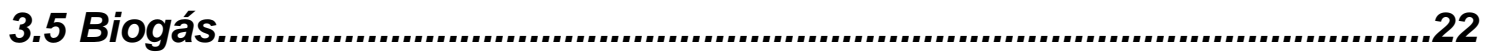

3.6 Biodigestão de resíduos de gado leiteiro para obtenção de biogás....29

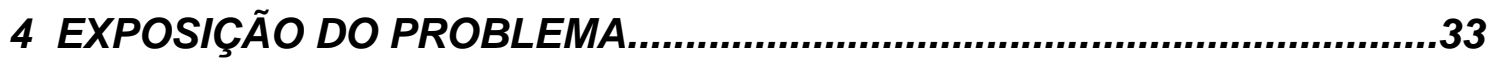

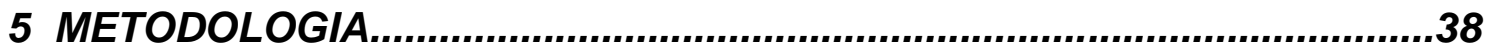

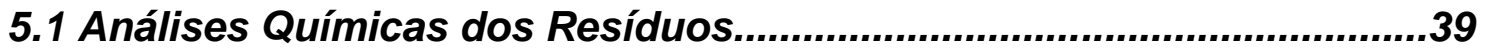

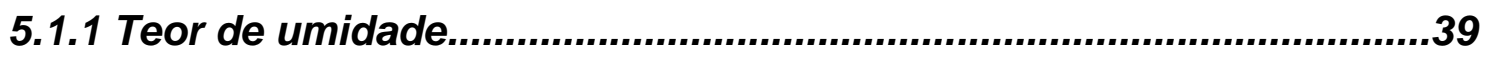

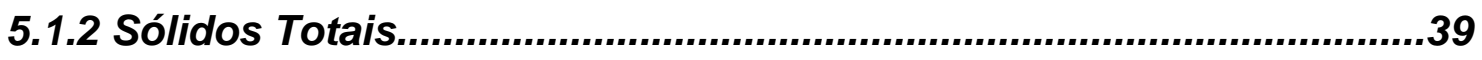

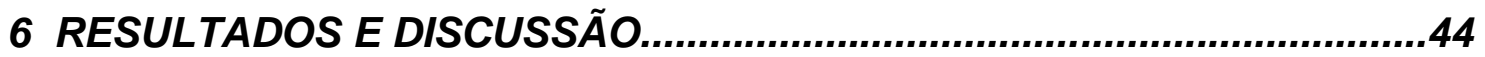

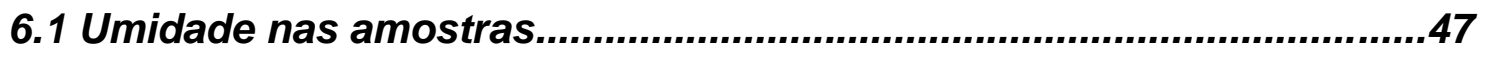

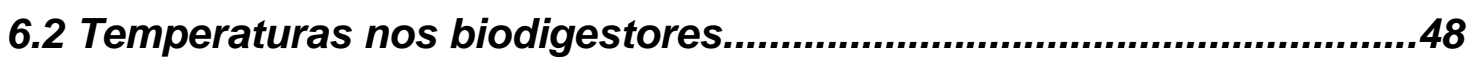

$6.3 \mathrm{pH}$ dos resíduos nos biodigestores....................................................49

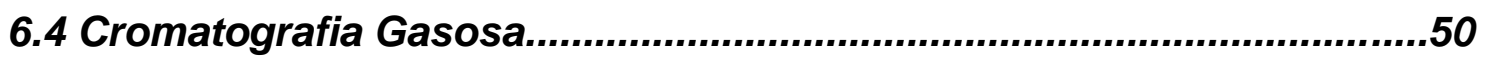

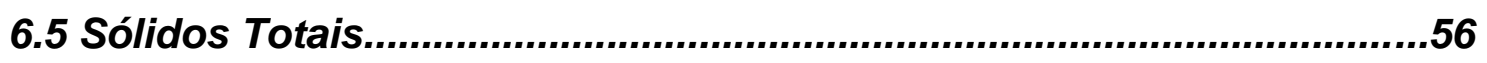

6.6 Análises por Espectrometria de Fluorescência de Raios-X.................56

7 CONCLUSÃO

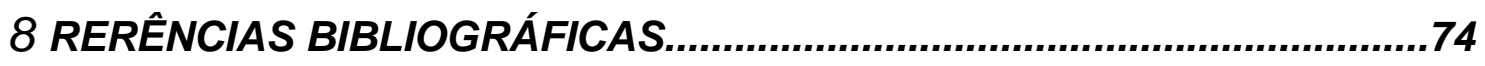




\section{GLOSSÁRIO}

Reses $=$ Gado bovino

Ordenha $=$ Ato de retirar $\mathrm{o}$ leite das vacas

UHT = Ultra High Temperature

IBGE = Instituto Brasileiro de Geografia e Estatística

$\mathrm{Ha}=$ Hectares

ONU = Organização das Nações Unidas

Chorume = Efluente Líquido Oriundo de Decomposição de Matéria Orgânica

$\mathrm{N}=$ Nitrogênio

$\mathrm{P}=$ Fósforo

$\mathrm{K}=$ Potássio

Oligoelementos $=$ Elementos químicos essenciais encontrados em baixa concentração nos organismos

Esterqueira $=$ Local onde se junta esterco

$\mathrm{DBO}=$ Demanda Bioquímica de Oxigênio

$\mathrm{CH}_{4}=$ Metano

$\mathrm{CO}_{2}=$ Dióxido de carbono

$\mathrm{N}_{2} \mathrm{O}=$ Óxido Nitroso

Propiônico = Ácido monocarboxílico

Butírico = Ácido monocarboxílico

$\mathrm{MDL}=$ Mecanismo de Desenvolvimento Limpo

$\mathrm{H}=$ Hidrogênio

$\mathrm{pH}=$ Potencial hidrogeniônico 
$\mathrm{H}_{2} \mathrm{~S}=$ Gás sulfídrico

$\mathrm{KVA}=$ Quilovoltampere

GPS = Sistema de posicionamento Global

Percolar $=$ Infiltrar

IQA = Índice de qualidade aquática

$\mathrm{Fe}=$ Ferro

$\mathrm{S}=$ Enxofre

Ti= Titânio

$\mathrm{Mn}=$ Manganês

$\mathrm{Zn}=$ Zinco

$\mathrm{Na}=$ Sódio

$\mathrm{kWh}=$ Quilowatt-hora

CIIAGRO= Centro integrado de informações agrometeorológicas

CONAMA $=$ Conselho Nacional de Meio Ambiente 


\section{INTRODUÇÃO}

O município de Lagoa da Prata localiza-se no centro oeste do Estado de Minas Gerais e pertence à micro região administrativa de Bom Despacho, inserido na bacia do rio São Francisco tendo altitude média em torno de 650m. $\mathrm{Na}$ figura 1 pode-se identificar a localização do município.

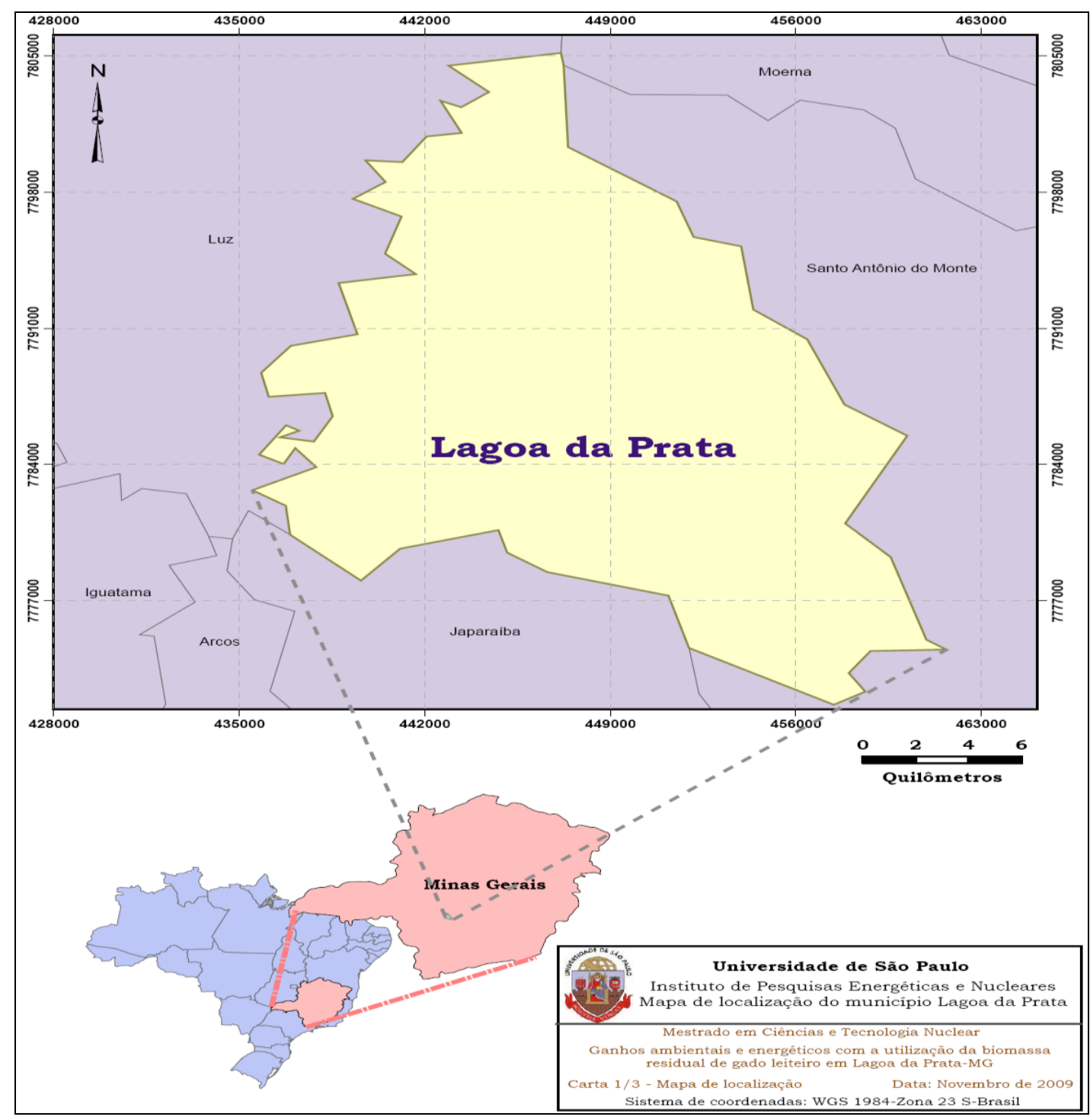

Figura 1 - Localização geográfica do município de Lagoa da Prata. Fonte: $\mathrm{O}$ autor 
A região é uma das grandes bacias leiteiras de Minas Gerais, sendo o município de Lagoa da Prata responsável pelo beneficiamento de aproximadamente um milhão de litros de leite diários. As reses se alimentam constantemente para obtenção de maior quantidade de leite e a ordenha acontece duas vezes ao dia. A criação e manejo do gado leiteiro se dão em boa parte em regime confinado.

A riqueza e o dinamismo econômico dessas atividades na região têm como base a exploração intensiva dos recursos naturais, que acaba por cobrar um preço alto do ambiente, o que já começa a se evidenciar pelos registros de contaminação do solo e das águas por agrotóxicos; pela perda de solos resultante da erosão; pela perda da cobertura vegetal e da biodiversidade; bem como pela produção de efluentes da pecuária (dejetos de suínos, aves e gado) e das cidades através de esgotos industriais e domésticos (Galinkin, 2009).

Os empreendimentos agropecuários distribuem-se em grande parte da zona rural do município. Com o aumento do consumo interno e externo de leite e seus derivados a região, tradicionalmente produtora de gado leiteiro, deixou de possuir apenas pequenos produtores de leite, para ter grandes empreendedores do agronegócio, fornecedores de matéria prima tanto para pequenos laticínios como para grandes indústrias de transformação de leite como a Embaré, Nestlé e Itambé.

Com a criação intensiva de gado leiteiro, diversos problemas ambientais acontecem. Nos locais de alimentação e ordenha do gado concentram-se grandes quantidades de resíduos orgânicos, que requerem tratamento correto para reduzir a poluição e a contaminação. Usar digestores anaeróbicos para processá-los torna-se uma opção atrativa, uma vez que o processo de digestão anaeróbia pode estabilizar biologicamente estes resíduos orgânicos e produzir biogás.

A biodigestão é um processo pelo qual se obtêm dois produtos valiosos que são o biofertilizante e o bioinseticida e ainda um subproduto nobre, o 
biogás. $\mathrm{O}$ biogás pode também ser chamado gás natural renovável porque pode ser usado como fonte de combustível para produzir eletricidade e calor, como o gás natural.

Também se observa na região um conjunto de paisagem bem alterada pela ação humana, principalmente pelas atividades de agricultura e agropecuária.

Cumpre destacar que todas as ações impactantes de forma negativa pela pecuária leiteira exercidas na região estão sujeitas a comprometer a calha do rio São Francisco. Na figura 2 é possível fazer uma leitura da localização dos empreendimentos agropecuários e suas proximidades com os corpos aquáticos na bacia hidrográfica do Rio São Francisco, na região estudada. 


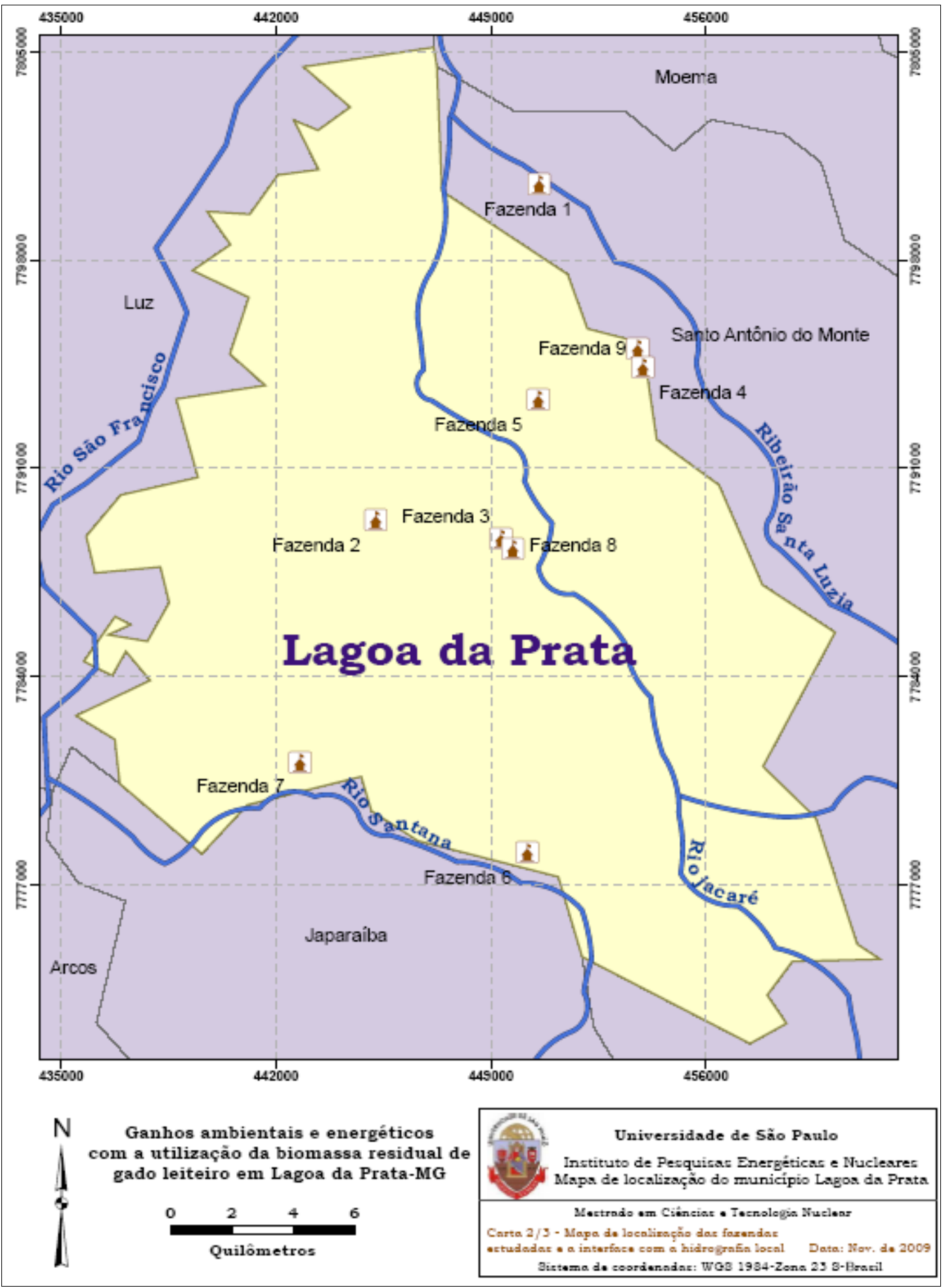

Figura 2- Localização das fazendas pesquisadas e interface com a hidrografia local.

Fonte: $\mathrm{O}$ autor 
Sendo assim, a região demanda uma série de medidas de preservação e controle ambiental em suas atividades econômicas. A implantação de biodigestores nas fazendas, além de uma alternativa tecnológica de controle ambiental, por tratar-se de um eficiente método de tratamento de efluentes e resíduos orgânicos, poderá servir de fonte de energia distribuída contribuindo com a melhoria de vida da população local. 


\section{OBJETIVO}

Este trabalho tem como foco principal o diagnóstico da biomassa residual de gado leiteiro confinado na região de Lagoa da Prata-MG, a partir de sua biodigestão anaeróbica, analisando potencial quantitativo e qualitativo do biogás para obtenção de metano como alternativa renovável na produção de bioeletricidade.

Visa também diagnosticar alguns empreendimentos agropecuários quanto aos aspectos: produtivo, energético, tecnológico e ambiental e analisar a implantação de biodigestores como alternativa para o controle e melhoria do meio ambiente nas fazendas e, consequentemente, na zona rural do município e da bacia hidrográfica regional. 


\section{REVISÃO BIBLIOGRÁFICA}

\subsection{Características do agronegócio leiteiro}

De acordo com a Companhia Nacional de Abastecimento (CNA), citado por FAGUNDES (2003) ${ }^{1}$, no ano de 2002 o Brasil foi o quinto maior produtor de leite do mundo, respondendo por cerca de $66 \%$ do volume total de leite produzido pelos países que compõem o Mercosul e 5,3\% da produção mundial.

Em 2002, o valor bruto da produção agropecuária foi de 139 bilhões de reais, sendo que aproximadamente 86,5 bilhões são de produtos agrícolas, dos quais 52,5 bilhões são de produtos pecuários, tendo o leite uma posição de destaque, com um valor de $\mathrm{R} \$ 8,64$ bilhões, ou seja, $16,5 \%$ do valor bruto da produção pecuária, superado apenas pelo valor da produção da carne bovina.

Já em 2007, a produção de leite foi estimada em 26,4 bilhões de litros, gerando um valor bruto da produção de aproximadamente 15 bilhões de reais. A sazonalidade da produção de leite é tema de grande importância para o setor por suas implicações nos vários agentes presentes na cadeia produtiva do leite (JUNQUEIRA ET AL, 2008).

O leite está entre os seis primeiros produtos mais importantes da agropecuária, ficando atrás somente da carne bovina, soja, carne de frango, cana de açúcar e do milho, mas por sua vez, a frente de produtos tradicionais da agricultura brasileira como o café beneficiado, arroz e carne suína. De acordo com o MME (2003), em 2002 o setor agropecuário representou 7,4\% do PIB nacional, contra $35,4 \%$ do setor industrial e $57,2 \%$ do setor de serviços, porém apresentou o maior índice de crescimento neste ano, chegando a 5,8\%, contra $1,5 \%$ da indústria e do setor de serviços.

De acordo com o IBGE citado por FAGUNDES (2003), o Brasil apresenta o terceiro maior rebanho mundial de vacas leiteiras somando, em 2002, cerca de 18,731 milhões de cabeças, representando cerca de $15 \%$ do 
rebanho mundial.

No ano de 2002, a produção brasileira de leite foi de 20,4 bilhões de litros, ${ }^{1}$ sendo que a importação de leite representou aproximadamente 7,15\% da produção interna, ou seja, cerca de 1,46 bilhões de litros. Neste mesmo ano, o consumo per capita de leite e derivados foi de 124,16 litros, cerca de metade do consumo verificado em países desenvolvidos. Do total de litros consumido no Brasil, apenas 1,9 \% é de leite tipo A e B; $4,9 \%$ são de leite tipo C; $19,5 \%$ de leite UHT e $73,7 \%$ de outros. Nos Estados Unidos e Canadá, para cada 200 pessoas, apenas uma consome leite longa vida (FAGUNDES, 2003).

Com relação à renda nacional, estima-se que cerca de $R \$ 18$ bilhões são gerados pelos diferentes segmentos que compõem o setor (CNA, 2001 citado por GOMES e ZOCCAL, 2001). De acordo com o IBGE (1996) citado por MARTINS e GUILHOTO (2001), registram-se aproximadamente 1,8 milhões de propriedades agrícolas destinadas à pecuária, ou seja, cerca de 1/3 das propriedades agrícolas brasileiras.

CAMPOS (1988), citado por AGUIAR(2001), afirma que aproximadamente 3,5 milhões de empregos são gerados na agroindústria leiteira, dos quais aproximadamente 1,8 milhões são de produtores, 41.650 são de empregos no setor de transportes e os demais são em laticínios. O setor emprega 3,5 vezes mais do que o setor da construção civil, 3,02 vezes mais do que o setor siderúrgico e 4,77 vezes mais do que o setor automobilístico.

O Censo de 1995-1996, realizado pelo IBGE, apurou que cerca de $44,1 \%$ da produção de leite nacional é oriundo de pequenas propriedades rurais com até 50 ha, que se dedicam exclusivamente à produção de leite. Estima-se que aproximadamente $36 \%$ de pequenos produtores de leite foram excluídos do mercado nacional, devido a dificuldades de se adaptarem ao novo cenário competitivo, LEITE BRASIL (2001) citado por MARTINS e GUILHOTO (2001).

\footnotetext{
${ }^{1}$ http://www.conab.gov.br/downloads/cas/especiais/LEITE\%2026\%20AGOSTO.pdf>.
} 


\subsection{Resíduos agropecuários e suas implicações ambientais}

Nos últimos anos, o destino final dos resíduos urbanos e industriais do agronegócio e a poluição ambiental tornaram-se assunto de grande relevância mundial, chegando até mesmo a serem alvos de uma grande conferência mundial promovida pela ONU, a "Il Conferência das Nações Unidas para o Meio Ambiente e Desenvolvimento", no Rio de Janeiro, em 1992. Esta conferência reuniu os principais estadistas do mundo para tratar dos problemas causados pelo homem ao Meio Ambiente e propor normas de conduta a serem seguidas por todos os habitantes do planeta, com a finalidade de reduzir a agressão causada pelo homem à natureza, em todos os níveis.

Esta conferência também teve como resultado um plano de ação denominado de Agenda 21 (Plano de ação da Declaração do Rio-92) onde, mais uma vez, os combustíveis alternativos e renováveis vieram à tona, como uma das soluções para o desenvolvimento auto-sustentado. Nesta conferência estabeleceu-se a substituição de $20 \%$ das fontes energéticas convencionais por renováveis até o ano 2000 e $50 \%$ até o ano 2020.

Hoje em dia, a gestão dos efluentes é uma grande preocupação para os bovinocultores: o desenvolvimento da pecuária intensiva, com elevadas concentrações de animais em áreas restritas, tem originado uma concentração de grandes quantidades de estrumes e chorumes, entre outros resíduos, cuja evacuação e destino final passam a constituir um problema preocupante. Esta situação agrava-se principalmente em explorações com áreas relativamente pequenas, onde a disponibilidade de terras de cultivo não é suficiente para assimilar a quantidade de resíduos produzidos, cumprindo os limites impostos pela legislação e seguindo os princípios de fertilização racional dos solos.

Além dos nutrientes, principalmente nitrogênio $(N)$, fósforo $(P)$ e potássio $(K)$ e oligoelementos (metais pesados sob a forma de óxido de zinco e sulfato de cobre), os dejetos pecuários bovinos provenientes de explorações intensivas possuem ainda quantidades substanciais de matéria orgânica, azoto 
amoniacal e outros compostos voláteis, responsáveis por maus cheiros, e agentes patogênicos que, não sendo geridos e processados adequadamente, trazem consequências nefastas para o meio ambiente (PAULO $E$ DOMINGUES, 2001).

Devido ao crescimento da população humana e em virtude da demanda sempre crescente por alimentos, a cada dia que passa os produtores de leite vêm adotando, por meio de confinamento, os "Sistemas Intensivos de Produção Animal". Isto ocorre principalmente próximo aos grandes centros consumidores, onde a poluição ambiental é um fator de grande risco à sobrevivência do homem e dos animais (CAMPOS, 1998).

O impacto ambiental do resíduo de gado leiteiro tem sido estudado por vários autores que estimam a contribuição das emissões de metano e amônia ao meio ambiente (Lodman et al.(1993); Havlikova et al., 2008), encontrando valores de cerca de $20 \%$ do total das emissões de metano na atmosfera e de 25\% das emissões de amônia (P. C. Garnsworthy, 2004). Alguns autores afirmam que a compactação e cobertura durante o armazenamento de bovinos também são importantes para o cálculo dos efeitos sofridos pelo meio ambiente (Chadwick, 2005; B. Amon et al., 2006)

Em sistemas de produção de leite de bovino, VAN HORN et al (1994) observou que as vacas eliminam nos dejetos 33\% da energia ingerida nos alimentos. Esta energia, junto com os constituintes minerais, pode ser fonte de poluição ao Meio Ambiente quando os dejetos são mal manejados. Já HARDOIM e GONÇALVES (1999), relata que o adequado manejo do resíduo é um requisito básico ao sucesso de qualquer empreendimento agropecuário. De forma mais simplificada, o bovino usado para a produção de leite pode ser analisado como uma máquina que processa o alimento convertendo apenas parte deste no produto leite, o restante é eliminado na forma de resíduo que possui uma grande capacidade de poluição.

Especificamente, quanto à quantidade de urina e de fezes eliminadas 
diariamente por algumas espécies de interesse zootécnico, tem - se, como citado por PEREIRA (1992), que: uma vaca elimina, por exemplo, o equivalente a $9 \%$ de seu peso por dia, sendo $60 \%$ fezes com teor de água de $85 \%$.

Assim, de uma forma cíclica, a poluição causada pelos resíduos pecuários acaba provocando danos ao próprio animal, ao homem que trabalha no sistema produtivo e ao Meio Ambiente como um todo, uma vez que pode ser a causa de doenças nos animais e no homem, ocasionando prejuízo ao próprio empreendimento.

Perante este panorama e com o crescente desenvolvimento de explorações que recorrem à produção intensiva estabulada, torna-se imprescindível a implementação de sistemas de gestão de resíduos pecuários que constituam alternativas eficazes e razoáveis do ponto de vista econômico, para o tratamento dos efluentes de origem bovina.

O emprego de tecnologia da digestão anaeróbia para o tratamento destes dejetos é possível e desejável, pois além de contribuir para preservação do Meio Ambiente, viabiliza os modernos sistemas de produção e otimiza a relação entre custo e benefício do empreendimento.

\subsubsection{Poluição do solo e da água}

No Brasil aumenta a cada dia o número de rebanhos, fazendo-se necessário um gerenciamento ambiental desta biomassa residual. Na tabela 1 observa-se que o volume de esterco produzido no país é alto, em função da quantidade de animais e que o gerado pelo gado bovino é bastante significante 
Tabela 1- Principais rebanhos e produção de esterco, efetivos em 31.12.2006

\begin{tabular}{|l|c|c|c|}
\hline \multicolumn{1}{|c|}{ Categorias } & $\begin{array}{c}\text { № de } \\
\text { cabeças } \\
(\times 1.000)\end{array}$ & $\begin{array}{c}\text { Produção de } \\
\text { esterco por } \\
\text { cabeça } \\
\text { (kg/d) }\end{array}$ & $\begin{array}{c}\text { Produção } \\
\text { total de } \\
\text { esterco } \\
\text { (t/ano })\end{array}$ \\
\hline Estabulados & 2.300 & 30,00 & 25.185 .000 \\
\hline $\begin{array}{l}\text { Vacas leiteiras (semi- } \\
\text { confinado ) }\end{array}$ & 20.943 & 15,00 & 114.662 .925 \\
\hline Criação extensiva & 182.643 & 10,00 & 666.646 .950 \\
\hline Total de bovinos & 205.886 & & \\
\hline Suínos & 35.174 & 4,40 & 56.489 .444 \\
\hline $\begin{array}{l}\text { Total de esterco dos } \\
\text { rebanhos }\end{array}$ & & 862.984 .319 \\
\hline
\end{tabular}

Fonte: Adaptado de Lucas e Silva (2005).

Quando o bovino é explorado no regime extensivo (pastejo), as dejeções produzidas são dispersas no solo e sofrem um processo completo de decomposição, sem maiores problemas de poluição. Isto ocorre devido à pequena concentração de animais por área de pastejo (GARCIA, 1981). Contudo, à medida que o animal fica confinado, mesmo que em um curto espaço de tempo, para ordenha, por exemplo, os dejetos produzidos ficam concentrados e necessitam ser tratados para evitar poluição.

A ocupação e uso do solo pelas atividades agropecuárias alteram sensivelmente os processos biológicos, físicos e químicos dos sistemas naturais. Estas alterações ocorridas em uma bacia hidrográfica podem ser avaliadas através do monitoramento da qualidade da água. Por meio do ciclo hidrológico, as chuvas precipitadas sobre as vertentes irão formar o deflúvio (escoamento) superficial que irá carrear sedimentos e poluentes para a rede de drenagem. Desta forma, o corpo hídrico receptor é um integralizador dos fenômenos ocorrentes nas vertentes da bacia, que pode ser avaliado pelos parâmetros de qualidade da água.

Pohlmann (2006), afirma que muitas fazendas, buscando elevar a produtividade, aumentam a concentração de animais na propriedade. $O$ resultado é uma grande produção de dejetos, que aplicados em uma pequena 
área, ultrapassam em muito a capacidade do solo e das plantas de absorvêlos. Portanto, esta prática deixa de ser uma fertilização para ser um descarte. Basta chover forte para que os dejetos escoem para áreas vizinhas e cursos d'água próximos.

O pisoteio intenso de animais tem causado preocupação a produtores e técnicos devido à possibilidade de compactação superficial, com conseqüente redução de aeração, tamanho de poros, infiltração de água e aumento da resistência do solo e estado de compactação que podem restringir o crescimento radicular e a produtividade das plantas (ALBERTTO et al., 2006).

Segundo Melo (1986), a construção de esterqueira para esterco sólido é praticamente ao nível do solo. Este tipo é adotado na maioria das pequenas propriedades e, em menor proporção, entre os grandes e médios criadores especializados. O tempo de exposição necessário para que ocorra a fermentação varia de 20 a 60 dias. A esterqueira para esterco líquido é utilizada por criadores nas regiões mais evoluídas tecnicamente e que possuem boa infraestrutura de mecanização, com equipamentos especializados para o carregamento, transporte e distribuição do esterco líquido.

Um dos maiores problemas destes sistemas é a grande quantidade de resíduos produzidos diariamente devido à elevada concentração de animais. Estes resíduos constituem-se de dejetos, de material usado nas camas, de água com produtos utilizados na limpeza, de restos de animais (pêlos e células mortas), entre outros. Os dejetos, que se constituem na maior parte dos resíduos, contêm a parte sólida, que são as fezes e a parte líquida, a urina. $\mathrm{O}$ destino final dos resíduos tem se constituído num problema para criadores e especialistas, pois envolve aspectos técnicos, sanitários e econômicos.

O comprometimento da qualidade da água para fins de abastecimento doméstico é decorrente de poluição causada por diferentes fontes, tais como efluentes domésticos, efluentes industriais e deflúvio superficial urbano e 
agrícola. Os efluentes domésticos, por exemplo, são constituídos basicamente por contaminantes orgânicos, nutrientes e microorganismos, que podem ser patogênicos. A contaminação por efluentes industriais é decorrente das matérias-primas e dos processos industriais utilizados, podendo ser complexa, devido à natureza, concentração e volume dos resíduos produzidos. A legislação ambiental tem estabelecido regras para o lançamento de efluentes industriais e a tendência é de existir um maior controle sobre esses poluentes.

Os poluentes resultantes do deflúvio superficial agrícola são constituídos de sedimentos, nutrientes, agroquímicos e dejetos animais. Para as condições brasileiras, não se tem quantificado o quanto esses poluentes contribuem para a degradação dos recursos hídricos. Nos Estados Unidos, no entanto, admitese que $50 \%$ e $60 \%$ da carga poluente que contamina os lagos e rios, respectivamente, são provenientes da agricultura (PIMENTEL, ET AL, 1992).

Desta forma, existe um consenso geral de que a atividade agropecuária rege uma importante função na contaminação dos mananciais, sendo uma atividade com alto potencial degradador e que a qualidade da água é um reflexo do uso e manejo do solo da bacia hidrográfica em questão (PAULO E DOMINGUES, 2001).

Uma grande fonte difusa de poluição do solo e da água é a causada pelas atividades de pecuária em sistemas de confinamento, como a pecuária de leite. Os problemas causados por essa atividade tende a crescer no Brasil devido, principalmente, ao crescimento do consumo interno e da exportação de derivados de leite.

Sendo assim, as atividades da pecuária leiteira representam riscos à contaminação das águas, devido à grande produção de resíduos altamente ricos em nutrientes produzidos e lançados ao solo e nos cursos de água sem tratamento prévio.

O material produzido por sistemas de criação confinada de gado leiteiro 
é rico em nitrogênio, fósforo e potássio, e seu material orgânico apresenta uma alta $\mathrm{DBO}_{5}$, sigla que corresponde ao oxigênio consumido na degração da matéria orgânica a uma temperatura média de $20^{\circ} \mathrm{C}$ durante 5 dias.

São 0 fósforo e a alta $\mathrm{DBO}_{5}$ que causam grandes impactos aos ecossistemas aquáticos de superfície, sendo o fósforo responsável pelo processo de eutrofização das águas e a $\mathrm{DBO}_{5}$ pela redução do oxigênio disponível. Já o nitrogênio oferece mais risco de contaminação da água subterrânea quando lixiviado. A utilização de dejetos como fertilizantes sem tratamento prévio também pode contribuir para a contaminação dos recursos hídricos se as quantidades aplicadas forem superiores à capacidade do solo e das plantas de absorverem os nutrientes presentes nesses resíduos. Dessa forma, poderá haver contaminação das águas superficiais pelo deflúvio, quando a capacidade de infiltração da água no solo for baixa e contaminação das águas subterrâneas, quando a infiltração da água no solo for elevada (Pote et al., 2001).

Hoje, no Brasil, como não poderia ser diferente, se faz necessário o adequado manejo dos resíduos, tendo em vista a necessidade de preservação ambiental. Isto se faz tanto pelo aspecto prático e racional, como também pelo aspecto legal, uma vez que existem leis que regulamentam o assunto, em nível federal, estadual e municipal. Em nível federal, temos a Lei $n^{\circ} 24.043$, de 10 de junho de 1934, conhecida como Código das Águas, e a Lei n 9.605, de 12 de fevereiro de 1998, chamada de Lei de Crimes Ambientais, que regulamenta as atividades ligadas ao Meio Ambiente. Contudo, em cada região podem existir leis, de âmbito estadual e municipal, que estabeleçam particularidades relacionadas a cada situação, atendendo aos requisitos mínimos das leis federais.

Com o objetivo de atender às exigências práticas e legais, torna-se necessário o desenvolvimento de tecnologia apropriada para o tratamento dos resíduos a cada caso, tornando mais eficiente o tratamento e minimizando, deste modo, o impacto ambiental que estes podem provocar. 


\subsubsection{Poluição Atmosférica}

A agricultura e a pecuária contribuem para as emissões antrópicas de metano $\left(\mathrm{CH}_{4}\right)$, dióxido de carbono $\left(\mathrm{CO}_{2}\right)$ e óxido nitroso $\left(\mathrm{N}_{2} \mathrm{O}\right)$ à atmosfera. $\mathrm{O}$ aumento da concentração desses gases provoca o aquecimento da superfície terrestre e destruição da camada de ozônio na estratosfera. Os países mais desenvolvidos têm sido apontados como os principais responsáveis pela situação atual da atmosfera do planeta. No entanto, as estimativas realizadas nos países em desenvolvimento, localizados na região tropical, também os classificam como importantes emissores de gases de efeito estufa, uma vez que as condições climáticas dessa região aumentam em muito o potencial de emissão de gases como o $\mathrm{CH}_{4}$, que já contribui com $15 \%$ para o forçamento radiativo global (Cotton \& Pielke, 1995). A taxa de $\mathrm{CH}_{4}$ emitido pelos ruminantes domésticos é considerada a terceira maior fonte em escala global (Estados Unidos, 2000).

A produção de $\mathrm{CH}_{4}$ expelido é parte do processo digestivo dos herbívoros ruminantes e ocorre no rúmen. A fermentação que ocorre durante o metabolismo dos carboidratos do material vegetal ingerido é um processo anaeróbio efetuado pela população microbiana ruminal, que converte os carboidratos celulósicos em ácidos graxos de cadeia curta, principalmente ácidos acético, propiônico e butírico. Nesse processo digestivo, parte do carbono é concomitantemente transformada também em $\mathrm{CO}_{2}$. A emissão de $\mathrm{CH}_{4}$ varia entre $4 \%$ e $9 \%$ da energia bruta do alimento ingerido, e a média encontrada é de $6 \%$ (USEPA, 2000).

$\mathrm{O} \mathrm{CH}_{4}$ é um gás cujo efeito estufa é estimado em, no mínimo, 21 vezes o do $\mathrm{CO}_{2}$ (Bley. 2008a). Assim, o sequestro, que poderia ser realizado processando a biomassa residual dos criatórios e confinamentos brasileiros, seria de 16,6 milhões de toneladas equivalentes de $\mathrm{CO}_{2}$.

De acordo com Delgado e outros (1999), a pecuária mundial emitiria 88 milhões de toneladas de $\mathrm{CH}_{4}$, das quais 17,6 milhões de toneladas são 
provenientes da biodigestão dos seus dejetos.

A emissão global de $\mathrm{CH}_{4}$ pelos processos entéricos é estimada em cerca de 80 teragramas ao ano $(\mathrm{Tg})$, correspondendo a $22 \%$ da emissão total de $\mathrm{CH}_{4}$ gerada por fontes antrópicas e a emissão proveniente de dejetos animais são estimadas em cerca de $25 \mathrm{Tg} / \mathrm{ano}$, correspondendo a $7 \%$ da emissão total (USEPA, 2000).

Conforme dados da tabela 1 observa-se que, no Brasil, grande parte do efetivo da pecuária é representada por bovinos de corte e por gado leiteiro, sendo considerado um dos maiores rebanhos de bovinos do mundo para fins comerciais, tornado-o um grande contribuinte em emissão de $\mathrm{CH}_{4}$ tendo como fonte os dejetos destes animais.

Somente as categorias de bovinos de corte e de leite somam $96 \%$ das emissões de $\mathrm{CH}_{4}$ provenientes da fermentação entérica na pecuária do País. A Embrapa Meio Ambiente coordenou, no período de 1996 a 1999, a elaboração do inventário da emissão de gases de efeito estufa provenientes de atividades agrícolas no Brasil (Lima et al., 2001), incluindo a emissão de $\mathrm{CH}_{4}$ pela fermentação entérica e por resíduos animais. Novo inventário encontra-se em fase de elaboração pelo MCT.

Portanto, um manejo adequado dos resíduos é uma necessidade sanitária, ecológica e econômica. Sanitária porque os resíduos podem prejudicar a saúde dos animais e do homem, tanto dentro como fora da propriedade. Ecológica, porque os resíduos, ricos em matéria orgânica e nutrientes, causam poluição e desequilíbrio ao Meio Ambiente e econômica, porque o tratamento dos resíduos envolve recursos em equipamentos, material e mão de obra, que oneram o sistema produtivo e podem até mesmo inviabilizá-lo.

Segundo Kiehl (1985), no Brasil é comum encontrar proprietários que coletam os dejetos e os aplicam diretamente no campo. As aplicações diretas 
do estrume fresco nas pastagens ou nas terras de cultura têm sido encaradas mais como uma maneira prática e econômica de descartar um resíduo agrícola do que realizar corretamente uma fertilização orgânica.

Um aspecto positivo dos sistemas pecuários é que os resíduos orgânicos são insumos de produção agrícola, quando estabilizados e reciclados adequadamente no solo, podendo incrementar a produção. Isto porque os resíduos constituem-se, na sua grande maioria, de dejetos que são componentes orgânicos naturais do meio e em última instância, quando adequadamente tratados, podem contribuir para a melhoria da produção vegetal e por conseqüência da produção animal. Assim, embora sejam chamados de resíduos com grande capacidade de poluição, na verdade são, de fato, recursos a serem reciclados no ecossistema natural (VAN HORN et al., 1994).

O desenvolvimento da tecnologia de utilização da digestão anaeróbia é um dos mais promissores no campo da biotecnologia, uma vez que é fundamental para promover, com grande eficiência, a degradação de resíduos orgânicos, que são gerados em grandes quantidades nas modernas atividades rurais e industriais. À medida que os sistemas de produção animal se intensificam e se modernizam, se intensificam também as necessidades energéticas e de tratamento dos resíduos (LUCAS JÚNIOR, 1987).

\subsection{Biodigestão Anaeróbia}

Digestão anaeróbica é um processo através do qual a matéria orgânica, como estrume, sobras de alimentação, resíduos de carne e resíduos vegetais são estabilizados por microrganismos estritamente na ausência de ar. Durante esse processo, alguns compostos orgânicos são convertidos, principalmente, nos gases metano $\left(\mathrm{CH}_{4}\right)$ e dióxido de carbono $\left(\mathrm{CO}_{2}\right)$. 
Na prática, tanques especialmente concebidos e isolados são utilizados para facilitar o processo de digestão anaeróbia sob uma atmosfera controlada. Os efluentes provenientes do digestor, após a conclusão deste processo, têm valor nutritivo e podem ser aplicados ao solo, tendo a vantagem de possuir muito menos odor, em comparação com o estrume armazenado (Navaratnasamy e Papworth, 2007 ).

Estudos em reatores anaeróbicos têm sido realizados no que diz respeito à remoção de sólidos, produção de biogás e destruição de bactérias coliformes (Dugba e Zhang, 1999; Summers et al. 1987; D.T. Hill, 1983)

A biodigestão anaeróbia proporciona diversas vantagens, entre elas podem-se citar: produção de gás combustível, controle e poluição das águas, controle dos odores, valorização do efluente residual como biofertilizante e bioinseticida, remoção dos agentes patogênicos da matéria orgânica. Tais benefícios direcionam ao Mecanismo de Desenvolvimento Limpo (MDL) que ainda possibilita acesso aos créditos de emissões reduzidas.

\subsection{Aspectos históricos sobre o biogás}

O biogás, antigamente conhecido como gás dos pântanos, foi descoberto por Shirley, em 1667. Já no século XIX, Ulysse Gayon, aluno de Louis Pasteur, realizou a fermentação anaeróbia de uma mistura de estrume e água, a $35^{\circ} \mathrm{C}$, conseguindo obter 100 litros de gás por metro cúbico de matéria. Em 1884, Louis Pasteur apresentou à Academia das Ciências os trabalhos do seu aluno e considerou que essa fermentação poderia constituir uma fonte de aquecimento e iluminação (NOGUEIRA, 1986).

$\mathrm{Na}$ Índia, a idéia de aproveitar o gás $\mathrm{CH}_{4}$ produzido por biodigestão anaeróbia já existia no século XIX, mais precisamente no ano de 1859, quando em uma colônia de leprosos, em Bombaim, foi feita a primeira experiência de 
utilização direta de biogás. Em 1895, trinta e seis anos depois, teve lugar a primeira experiência européia com a utilização do biogás para iluminação de algumas ruas da cidade de Exter, na Inglaterra, a que se seguiram outras experiências motivadas principalmente pelo entusiasmo inicial que esse processo causou. Apesar disso, o combustível não conseguiu vingar como substituto dos combustíveis tradicionais, porque sua utilização foi muito reduzida, limitando-se a alguns casos esporádicos. Apenas em 1940, devido a carências energéticas significativas provocadas pela II Guerra Mundial, o biogás voltou a ser utilizado na cozinha, no aquecimento das casas, ou ainda na alimentação de motores de combustão interna (NOGUEIRA, 1986).

Em meados do século XX, nas décadas de 50 e 60, a relativa abundância das fontes de energia tradicionais desencorajou a recuperação do biogás na maioria dos países desenvolvidos. Apenas em países com poucos recursos de capital e energia, como a Índia e a China, o biogás desempenhou papel importante, sobretudo nos pequenos aglomerados rurais. Porém, a partir da crise energética dos anos 70 , o gás $\mathrm{CH}_{4}$ dos digestores anaeróbios voltou a despertar interesse geral, o que conduziu ao aumento de sua produção nos países europeus (NETO, 2006).

No Brasil este conceito foi introduzido através da instalação do primeiro digestor, de concepção indiana, na Universidade Federal do Rio de Janeiro, em 1949, sendo que, em 1980, a EMBRATER (Empresa Brasileira de Assistência Técnica e Extensão Rural) instalou em Brasília o primeiro modelo Chinês, na Granja do Torto.

Em 1986 a situação do Brasil, segundo dados da EMBRATER, era de 7520 digestores instalados no meio rural, número que conferiu ao país o terceiro lugar no mundo, tanto em número de unidades como em recursos financeiros aplicados em pesquisa e difusão de tecnologia, sendo ultrapassado apenas pela China e a Índia. No entanto, grande parte desses digestores foi desativada. Dentre os motivos mais citados para explicar a limitação e o descrédito na adoção desta tecnologia, incluem-se a interrupção do crédito 
rural específico em 1985 e a falta de seriedade de algumas empresas fabricantes de equipamentos que projetaram produções de biogás acima das realizáveis.

Assim, a viabilidade do uso do biogás é sempre lembrada em épocas de crise. Na Segunda Guerra Mundial quando os alemães e italianos acionavam trens e caminhões com biogás, no Brasil foram construídos vários biodigestores. Passada a crise o biogás foi esquecido, sendo lembrado em 1973 com a crise do petróleo quando, mais uma vez, ouve interesse em se produzir biogás no Brasil, sendo que o Ministério de Minas e Energia e a Eletrobrás financiaram a construção de plantas pilotos para a divulgação desta tecnologia (NETO, 2006).

Após a crise do petróleo houve uma desativação de todos os programas de energia alternativa, inclusive do PRÓ-ALCOOL que era um programa mais ambicioso do que o do biogás.

O biogás já perdeu várias batalhas contra os derivados de petróleo, entretanto deve-se lembrar que esta fonte de energia é renovável e o petróleo não. Com o tratado de Quioto, mais uma vez as fontes de energia alternativas ganharam destaques por não agravarem o problema do efeito estufa lançando mais $\mathrm{CO}_{2}$ na atmosfera.

O biogás é uma fonte de energia renovável, economicamente viável e não poluidora, por se encaixar naturalmente no ciclo do carbono.

\subsection{Biogás}

O biogás é também conhecido como gás dos pântanos ou gás de esgoto, por ser naturalmente produzido nestes ambientes. Estima-se que a formação de $\mathrm{CH}_{4}$ seja responsável pela mineralização de 5 a $10 \%$ de toda a matéria orgânica disponível na terra. O cheiro característico do biogás se deve 
à presença de gás sulfídrico, que funciona como um indicador de vazamento, quando se utiliza o biodigestor para produção de energia de uso doméstico. Tal como o gás natural, o biogás também pode ser usado como combustível em geradores, motores, caldeiras e queimadores.

O biogás é composto de cerca de 50 a $70 \%$ de $\mathrm{CH}_{4}$ e de 30 a $50 \%$ de $\mathrm{CO}_{2}$, com traços de $\mathrm{H}_{2} \mathrm{~S}, \mathrm{H}, \mathrm{N}$, entre outros. $\mathrm{CH}_{4}$ e $\mathrm{CO}_{2}$ representam $99 \%$ do volume total do biogás e desta fração apenas $0 \mathrm{CH}_{4}$ é combustível. $\mathrm{O} \mathrm{CH}_{4}$ puro possui um poder calorífico de $8.703 \mathrm{Kcal} / \mathrm{m}^{3}$. Considerando-se um biogás com $60 \%$ de $\mathrm{CH}_{4}$ este apresentaria um poder calorífico de $5.222 \mathrm{kcal} / \mathrm{m}^{3}$, podendo ser utilizado em substituição aos derivados de petróleo, lenha, álcool etc. (NETO, 2006).

A produção de biogás emprega tecnologia simples e barata, sendo fundamentada na anaerobiose, ou seja, através da decomposição de matérias orgânicas diversas, como dejetos, restos de culturas, podas, palhas entre outras. A ausência de oxigênio é obtida com a construção do biodigestor que se trata de um recipiente fechado construído em alvenaria, concreto, ferrocimento, fibra de vidro entre outros, onde é colocada a matéria prima a ser digerida. Qualquer matéria orgânica pode ser utilizada para a produção do biogás, entretanto, para uma utilização racional, devem-se observar parâmetros operacionais, econômicos e adaptar o tipo de biodigestor a ser empregado com a natureza da matéria orgânica.

A temperatura ideal para a digestão anaeróbia, situada na faixa mesofílica, é de aproximadamente $35^{\circ} \mathrm{C}$. Caso haja interesse em que esta temperatura seja mantida no interior do digestor é necessária, na maioria dos casos, a utilização de sistema de isolamento térmico e aquecimento. A importância do emprego destes sistemas baseia-se no fato que, a temperaturas mais elevadas, a velocidade de reação é maior, sendo requerido um volume menor do digestor, o que afeta diretamente 0 custo das instalações (BENINCASA et. al.,1991). 
O tempo de retenção varia em função do tipo de biomassa, granulometria da biomassa, temperatura do digestor, $\mathrm{pH}$ da biomassa, etc., mas de modo geral, situa-se na faixa de 4 a 60 dias. Normalmente, o tempo de digestão para esterco de animais domésticos situa-se na faixa de 20 a 30 dias (COMASTRI FILHO, 1981).

Vários trabalhos encontrados na literatura estabelecem que a quantidade de $\mathrm{CH}_{4}$ produzida possa ser uma função direta da dieta alimentar do gado (J.E. Wohlt, 1990; Sylvie Giger-Reverdinet al., 2003; J.L. Ellis et al., 2007; Thomas Amon et al., 2007; K.A. Beauchemin et al., 2009), assim como da raça do gado leiteiro (A. Münger e M. Kreuzer, 2006).

Vários fatores influem na produção do biogás, porém todos são perfeitamente controláveis. Segundo BATISTA (1980) citado por COMASTRI FILHO (1981), a produção do biogás nada mais é do que uma função da composição da matéria prima utilizada e da eficiência do sistema digestor, além de outros fatores.

Como citado, o biogás não é $\mathrm{CH}_{4}$ puro, sendo que sua composição pode depender, sobretudo, dos materiais adicionados na biodigestão. Uma composição típica é mostrada na tabela 2 
Tabela 2 - Composição típica de biogás produzido por digestão anaeróbica

\begin{tabular}{|c|c|c|}
\hline Gás & $\begin{array}{c}\text { \% em volume por } \mathrm{m}^{3} \text { de } \\
\text { biogás }\end{array}$ & Fórmula Química \\
\hline Metano & $55-75$ & $\mathrm{CH}_{4}$ \\
Dióxido de Carbono & $25-45$ & $\mathrm{CO}_{2}$ \\
Nitrogênio & $0-3$ & $\mathrm{~N}_{2}$ \\
Hidrogênio & $0-2$ & $\mathrm{H}_{2}$ \\
Oxigênio & $0-0,1$ & $\mathrm{O}_{2}$ \\
Gás Sulfídrico & $0-1$ & $\mathrm{H}_{2} \mathrm{~S}$ \\
& & \\
\hline
\end{tabular}

Fonte: Nogueira, 1986.

Algumas vezes a presença de nitrogênio e oxigênio no biogás pode indicar que o sistema não está estanque, devendo existir algum vazamento. $\mathrm{A}$ formação de gás sulfídrico é governada pela concentração de compostos de enxofre e pela atividade das bactérias redutoras de sulfatos. Embora usualmente presente apenas em quantidades ínfimas, teores de $\mathrm{H}_{2} \mathrm{~S}$ de até $5 \%$ podem ser encontrados em alguns casos, especialmente para resíduos industriais.

O volume de biogás produzido por unidade de peso de matéria orgânica é variável e depende de diversos fatores como temperatura, tipo de biodigestor e, fundamentalmente, do tipo de material orgânico empregado, como pode ser observado na tabela 3 . 
Tabela 3 - Valores de produtividade de biogás

\begin{tabular}{|c|c|c|c|}
\hline Material & $\begin{array}{c}\text { Produtividade } \\
\left(\mathrm{m}^{3} / \mathrm{kg}\right)\end{array}$ & $\begin{array}{c}\text { Material } \\
\text { de } \\
\left(\mathrm{m}^{3} / \mathrm{kg}\right)\end{array}$ \\
\hline $\begin{array}{c}\text { Esterco bovino fresco } \\
\text { fresco }\end{array}$ & 0,04 & $\begin{array}{c}\text { Resíduos vegetais } \\
\text { secos }\end{array}$ & 0.30 \\
Esterco suíno seco & 0,43 & $\begin{array}{c}\text { Resíduo } \\
\text { matadouro(úmido) }\end{array}$ & 0,07 \\
\hline
\end{tabular}

Fonte: Nogueira, 1986.

$\mathrm{O}$ poder calorífico do biogás depende de seu teor de $\mathrm{CH}_{4}$ e grau de umidade. $\mathrm{O}$ gás contém grande quantidade de água, pois a digestão se dá em meio úmido e satura de vapor d’água o biogás produzido. Um valor frequentemente adotado para o poder calorífico é $5500 \mathrm{kcal} / \mathrm{m}^{3}$. Se o gás é desumidificado, o poder calorífico aumenta e se o dióxido de carbono é removido, por borbulhamento em solução alcalina, seu valor aproxima-se do correspondente ao $\mathrm{CH}_{4}$ puro, $9000 \mathrm{kcal} / \mathrm{m}^{3}$ (Nogueira, 1986).

Cada metro cúbico de biogás equivale a uma determinada quantidade de outro combustível, conforme indicado na tabela 4. 
Tabela 4 - Equivalência energética para $1 \mathrm{~m}^{3}$ de biogás

\begin{tabular}{|l|l|l|l|}
\hline Combustível & Massa & Combustível & Massa \\
\hline Carvão Vegetal & $0,8 \mathrm{~kg}$ & Querosene & $0,62 \mathrm{~L}$ \\
\hline Óleo diesel & $3,5 \mathrm{Kg}$ & $\begin{array}{l}\text { GLP ( butano- } \\
\text { propano }\end{array}$ & $1,43 \mathrm{Kg}$ \\
\hline Gasolina & $0,61 \mathrm{~L}$ & Xisto & $4,0 \mathrm{Kg}$ \\
\hline Álcool carburante & $0,80 \mathrm{~L}$ & Energia Elétrica & $1,2 \mathrm{KWh}$ \\
\hline
\end{tabular}

Adaptado de Nogueira, 1986.

Observa-se que, devido à sua baixa densidade, é preciso grande volume de biogás para fornecer a mesma energia dada por alguns outros combustíveis. No entanto, por possuir boas características e ser possível isolar o seu principal constituinte, o $\mathrm{CH}_{4}$, torna-se um combustível de grande valor. Quanto mais puro, maior é o seu poder calorífico, que pode atingir em torno de $50.251 \mathrm{~kJ} / \mathrm{m}^{3}$, com a retirada de $\mathrm{CO}_{2}$. A Figura 3 mostra o esquema de uma estação de purificação de biogás. Nesta figura pode ser observado como é simples o processo de purificação de biogás, pois emprega tecnologia barata e sem complexidade técnica. Logo, torna mais acessível e viável a implantação de uma estação deste modelo em um projeto de geração de bioeletricidade a partir do uso de biogás. 


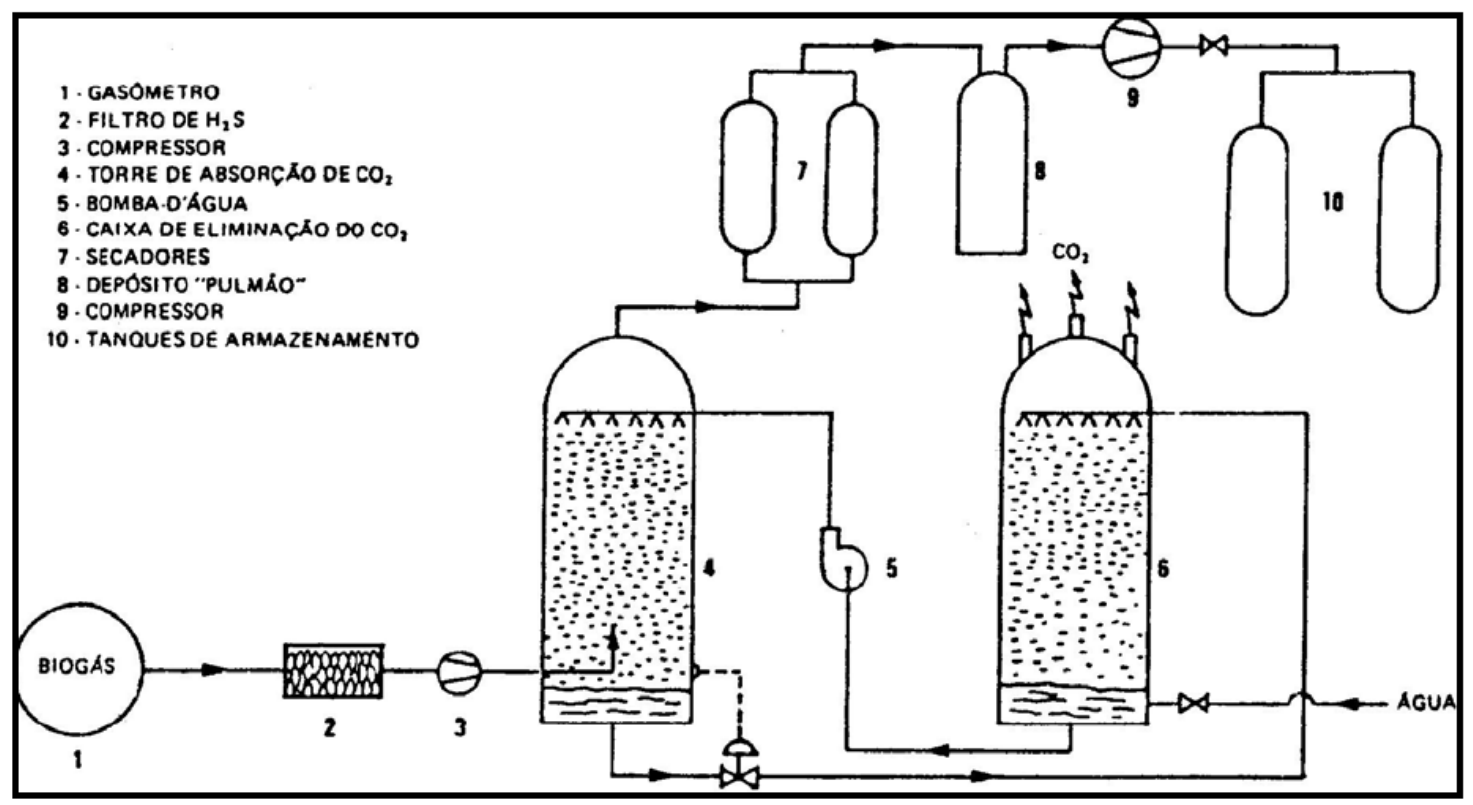

Figura 3- Esquema de uma estação de purificação de biogás a baixa pressão $\left(5 \mathrm{Nm}^{3} / \mathrm{h}\right)$ para uso automotivo [Fonte: : BEDUSCHI et al. (1985) citado por LUCAS JR \& SILVA (s.d.)].

Segundo Keenan (1989), a elevada eficiência energética propiciada pela biodigestão é da ordem de $60 \%$, sendo que estudos termodinâmicos dos processos que a constituem permitem avaliar qual a máxima produção teórica de biogás para cada substrato, mostrando que é possível atingir até $75 \%$ de eficiência. A eficiência é determinada como sendo a razão entre o poder calorífico do gás obtido e o poder calorífico da matéria orgânica.

Jewell (1981) demonstra que no caso específico do esterco bovino a biodigestão seja quase 3 vezes mais oportuna que a pirólise e 14 vezes mais interessante que a incineração. Já Parikh (1980) apresentou uma comparação dos custos envolvidos no suprimento de energia e fertilizantes para pequenas propriedades na Índia, mostrando que a biodigestão sai aproximadamente 35\% mais barata que a compra de combustíveis e o uso do esterco sem biodigerir.

Por apresentar alta percentagem de $\mathrm{CH}_{4}$, o biogás é extremamente inflamável, podendo ser usado para vários fins. No meio rural é utilizado, principalmente, para: cocção, iluminação, refrigeração doméstica e aquecimento. Também pode ser usado no acionamento de motores a explosão 
e na geração de energia elétrica. A literatura consultada menciona várias utilizações para o biogás, desde aquecimento e iluminação até a alimentação de motores estacionários usados para irrigação e geração de energia elétrica, inclusive com tabelas que demonstram o consumo de biogás para algumas aplicações.

R. E. Agnew e T. Yan (2000) fazem uma revisão sobre o impacto em sistemas de geração de energia com o aproveitamento de resíduos do gado leiteiro

$\mathrm{Na}$ Tabela 5 apresenta-se o consumo de biogás para algumas utilizações.

Tabela 5- Consumo e pressão do biogás para algumas de suas utilizações

\begin{tabular}{|lcc|}
\hline \multicolumn{1}{|c}{ Tipo } & $\begin{array}{c}\text { Pressão de utilização } \\
\text { (m.c.a.) }\end{array}$ & Consumo \\
\hline Cocção & 6,0 a 15,0 & $0,034 \mathrm{~m}^{3} /$ pessoa.d \\
Iluminação & 5,0 a 10,0 & $0,07 \mathrm{~m}^{3} /$ camisa de $100 \mathrm{~W} . \mathrm{h}^{3}$ \\
Geladeira (absorção) & 10,0 & $3,10 \mathrm{~m}^{3} / \mathrm{dia}$ \\
Forno de assar & 10,0 & $0,42 \mathrm{~m}^{3} / \mathrm{h}$ \\
Aquecedor de ambiente & 10,0 & $0,23 \mathrm{~m}^{3} / \mathrm{h}$ \\
Chuveiro a gás & 10,0 & $0,15 \mathrm{~m}^{3} / \mathrm{pessoa}$ \\
Motor a explosão & 15,0 (mínimo) & $0,37 \mathrm{~m}^{3} / \mathrm{HP} . \mathrm{h}$ \\
Campânula de pintainhos & 10,0 & $0,29 \mathrm{~m}^{3} / \mathrm{h}$ \\
\hline
\end{tabular}

Fonte: IPT ( 1982 )

As fontes de energia não convencionais apresentam-se restritas a um determinado local, mas se mostram eficientes e com a grande vantagem de serem renováveis e não poluidoras. A não exploração destas fontes de energia se deve principalmente ao seu pequeno porte e à transferência de responsabilidade de seu funcionamento para o usuário, que prefere comprar um botijão de gás a alimentar um biodigestor sem uma análise econômica do processo (NETO, 2006). 


\subsection{Biodigestão de resíduos de gado leiteiro para obtenção de biogás}

O esterco bovino representa a matéria-prima por excelência para a produção de biogás, pelo fato de já possuir naturalmente os microorganismos responsáveis pela fermentação anaeróbia.

Como o esterco bovino deve ser diluído em água para uso no biodigestor, existe ainda a disponibilidade para utilização da água quente obtida com a assepsia da ordenha para diluição deste substrato a ser biodigerido. A adição de água quente favorece a operação do biodigestor dentro da faixa mesofílica, melhorando a digestão e a produção de biogás.

A água residual resultante da limpeza das instalações e equipamentos, ainda quente, mas a uma temperatura mais baixa é canalizada juntamente com os dejetos para o biodigestor. A construção do biodigestor com certo desnível em relação às instalações facilita a retirada dos dejetos, que seguem por gravidade. A adição da água também reduz o atrito com a tubulação adutora.

Diante da vocação agropecuária brasileira, em conjunto com sua dimensão territorial, observa-se uma demanda e carência de recursos energéticos e, ao mesmo tempo, a necessidade de tratar os resíduos agropecuários provenientes do agronegócio.

Portanto, em um sistema de produção de leite adequadamente planejado, a quantidade dos resíduos pode ser estimada e usada como recursos de suprimentos, tanto de energia como de biofertilizante. Porém, quando este é inadequadamente planejado, o excesso de resíduos pode se constituir em um problema e torna-se desperdício que causa desequilíbrio ambiental. Em tais circunstâncias, a sociedade tem que coibir este desequilíbrio e exigir que seja feito o processamento adequado, até mesmo quando os custos deste processamento excedem ao valor dos recursos 
recuperados.

Desta forma, o melhor sistema de tratamento do resíduo pecuário deve ser projetado para minimizar o impacto ao Meio Ambiente e maximizar a recuperação dos recursos energéticos e fertilizantes que estes contêm, com o objetivo de aproveitá-los no aumento da produtividade. Estudos vêm sendo feito em laboratórios para o tratamento e aproveitamento do $\mathrm{CH}_{4} \mathrm{com}$ algumas variáveis como a fermentação (M. D. Erdman, 1985), ou o tempo de incubação do resíduo (G. Getachew et al., 2005). Trabalho realizado no México conclui que os resultados sugerem que o fator dominante nas emissões de $\mathrm{CH}_{4}$ é a ração, seguida por fermentação temperatura e o teor de umidade das excretas (E. González-Avalos e L. G. Ruiz-Suárez, 2001)

Com a instalação de biodigestores, os empreendimentos poderão ganhar com controle ambiental, com o aproveitamento do resíduo para geração de insumos agropecuários, energia e possivelmente com os créditos de emissões reduzidas( CERs ), estabelecidos no mecanismo de desenvolvimento limpo (MDL) [Ministério de Ciência e Tecnologia, 2002].

A geração de energia a partir da biomassa animal encontrava-se, em 2008, em fase quase experimental, com poucas usinas de pequeno porte em operação no mundo. Por isso, em estatísticas e estudos, era tratada pela designação genérica de "outras fontes". Já para a biomassa de origem vegetal, o quadro era radicalmente diferente em função da diversidade e da aceitação de seus derivados pelos consumidores. (Atlas da Energia Elétrica do Brasil, 2008. Brasília: (Agência Nacional de Energia Elétrica:pg 68).

O biogás resultante da digestão da biomassa é inflamável em função da quantidade de $\mathrm{CH}_{4}$ que contém, uma característica que o habilita também para uso como combustível em turbinas e motores a explosão e, acoplando-se a estes um gerador, produz-se energia elétrica. O seu poder calorífico usual varia entre 5.000 e 7.000 quilocalorias por metro cúbico podendo chegar até 12.000 
kcal quando altamente purificado (Barrera, in Casagrande, 2003), portanto, com grande potencial de uso como energia térmica ou energia elétrica ao alimentar motogeradores.

Além disso, no caso de uso da biomassa residual transformada em energia elétrica para processos produtivos que ocorrem no espaço rural ou semi-rural (criatórios, frigoríficos, etc.) e que hoje demandam energia elétrica do Sistema Nacional Integrado, acontecerá - do ponto de vista desse sistema o que Sachs

corretamente classifica como a "energia que menos custa" (Sachs, 2007a:25), aquela que deixa de ser demandada no sistema que a gera em centrais, a transporta em linhas de transmissão e a entrega aos consumidores através de linhas de distribuição. Isso significa economia nos investimentos da logística da disponibilidade e para acesso da energia elétrica, e que sendo produzida pelas próprias atividades usuárias pode ser liberada para usos socialmente mais necessários (ampliação de linhas de metrôs, trens, hospitais, etc.).

Para alguns setores da agricultura, como a pecuária de leite, por apresentar hoje um uso intensivo de energia elétrica e uma grande dependência desta forma de energia, principalmente em processos de aquecimento e resfriamento, indispensáveis à boa qualidade do leite, atenção especial deve ser dada à produção de biogás que neste setor, devido à existência de grande quantidade de resíduos orgânicos, poderá proporcionar uma auto-suficiência energética.

Michael Liebreich, presidente da New Energy Finance30, um renomado especialista em energias renováveis, diz que estamos em plena reestruturação cultural e que levaremos pelo menos 20 anos para transformar nossos hábitos em relação à energia. É possível que esse prognóstico de tempo seja válido em se tratando da matriz energética global, porém, não é o que está ocorrendo em alguns países da Europa, que diante da escassez de fontes e visando atenuar a dependência de energias poluentes como o carvão e a nuclear, estabeleceram políticas públicas normatizadoras para a inclusão de energias 
renováveis em suas matrizes.

Diante do exposto, cumpre chamar a atenção para a importância da utilização dos resíduos de pecuária leiteira no Brasil como uma fonte renovável de energia, porque tal atitude é uma das diversas maneiras de se garantir o suprimento de energia e da constituição de um ambiente equilibrado no presente e no futuro. 


\section{EXPOSIÇÃO DO PROBLEMA}

O regime de criação de vacas leiteiras em Lagoa da Prata se dá de maneira confinada e semi-confinada. O rebanho, que se alimenta duas vezes diariamente, fica reunido próximo ao local de ordenha, que é realizada pela manhã e ao final de cada dia. É possível observar nas figuras 4 e 5 estes ambientes, onde o gado se encontra em boa parte do dia.

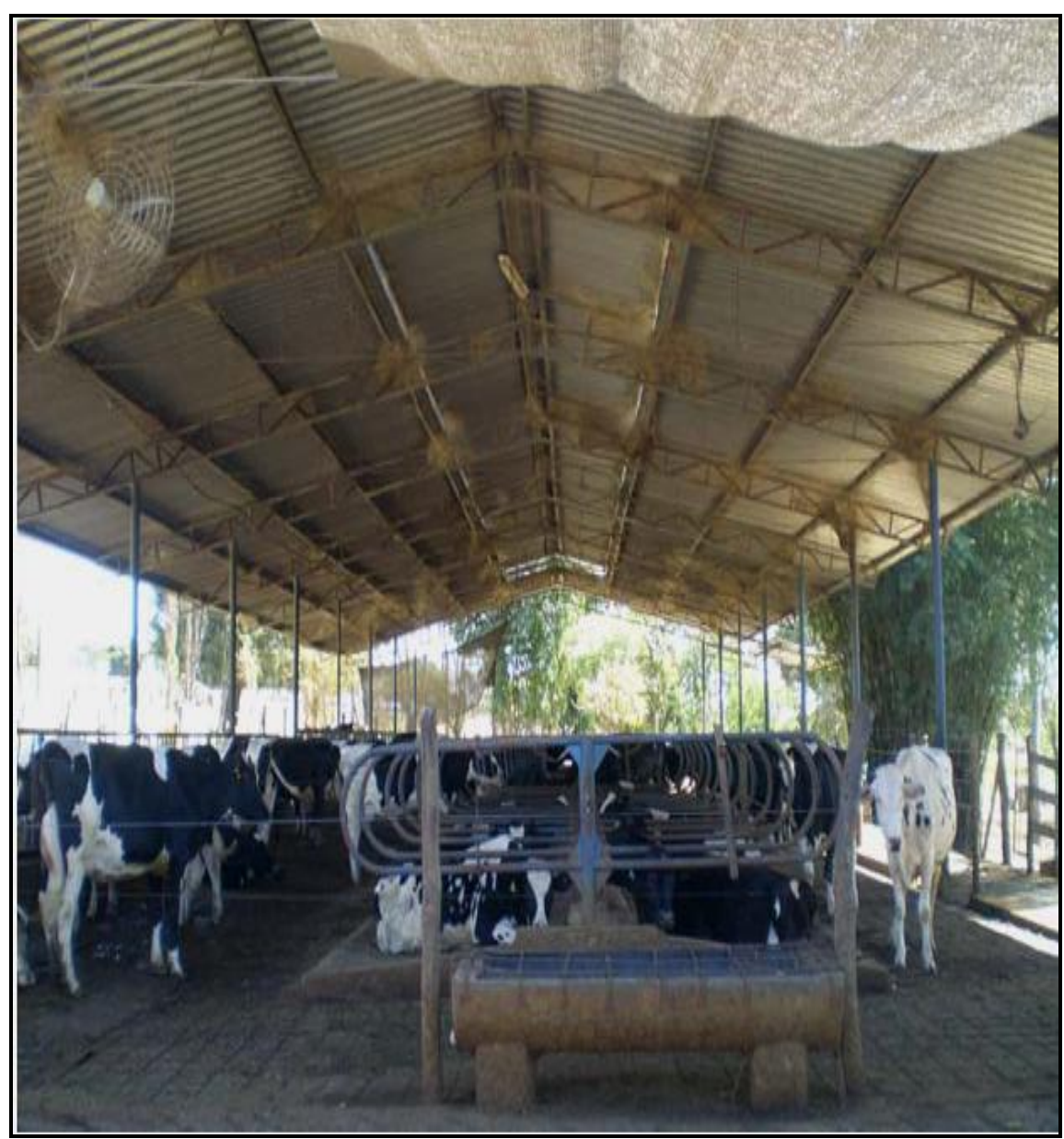

Figura 4 - Vacas estabuladas

Fonte: Elaboração própria 


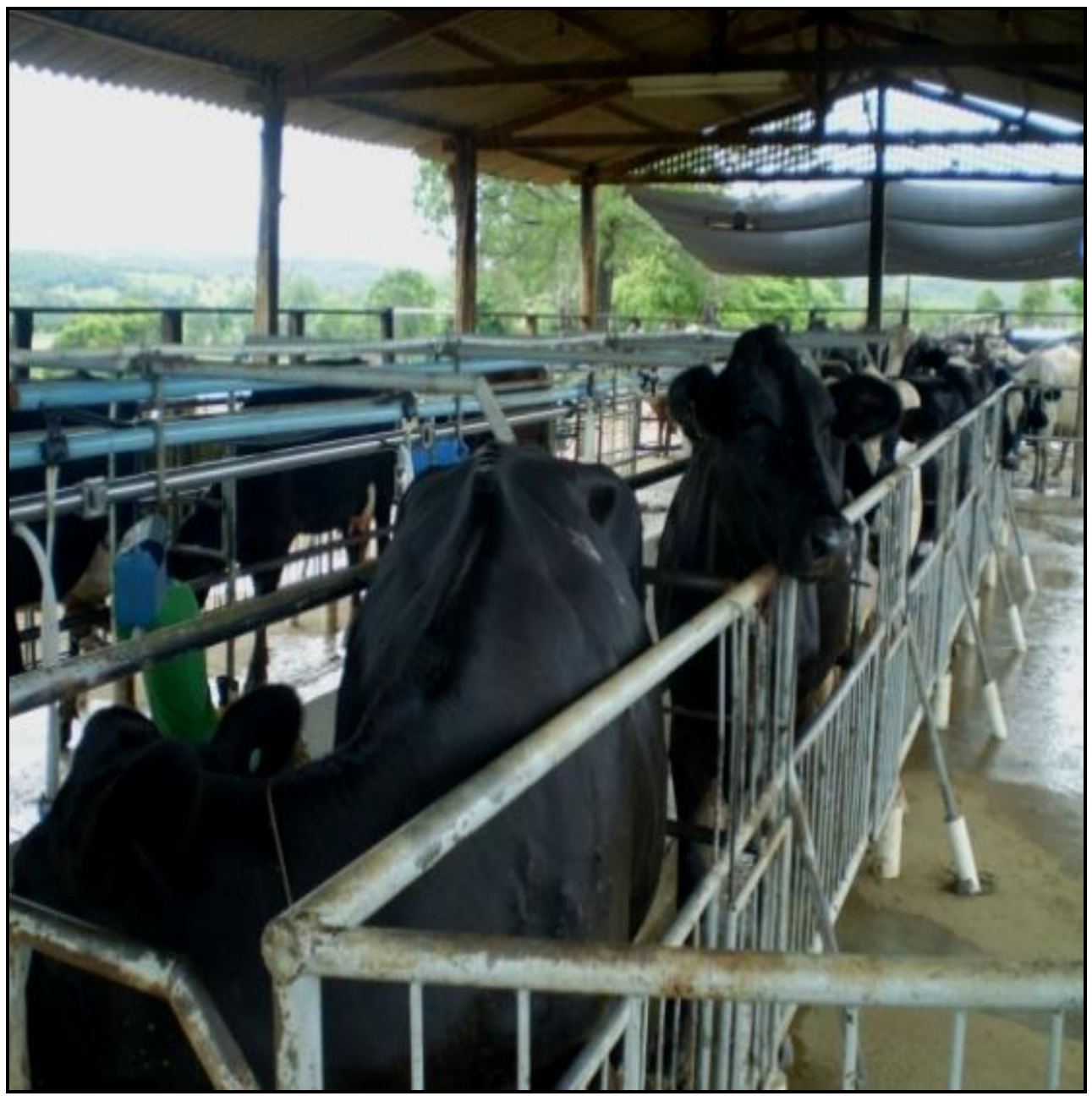

Figura 5- Vacas na ordenhadeira Fonte: Elaboração própria

Assim, nestes locais os animais ficam boa parte do tempo para se alimentar e dessedentar, tendo como conseqüência a geração de resíduos em grandes quantidades reunidos em um mesmo lugar. A limpeza destes ambientes é feita diariamente e pode-se observar pela figura 6 que se torna possível aproveitar este resíduo, pois ao se higienizar o piso através da raspagem e lavagem, toda biomassa pode ser conduzida por gravidade para um sistema de biodigestão, facilitando 0 recolhimento para 0 seu aproveitamento. 


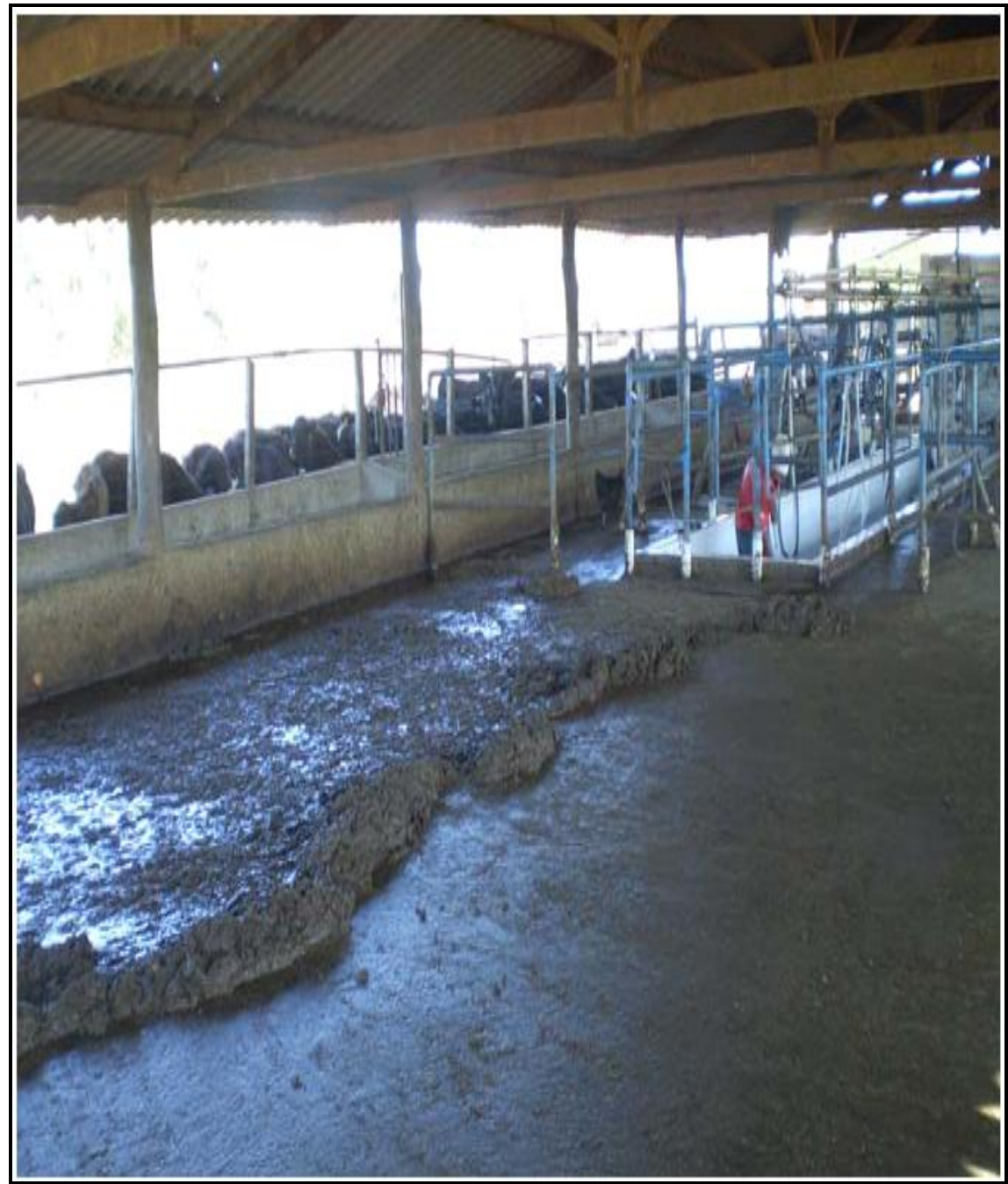

Figura 6- Resíduo gerado em ordenha

Fonte: Elaboração própria

Na figura 7, notam-se os resíduos dispostos de forma inadequada no solo, podendo comprometer todo o meio ambiente regional, uma vez que podem ser carreados para os corpos aquáticos na região. 


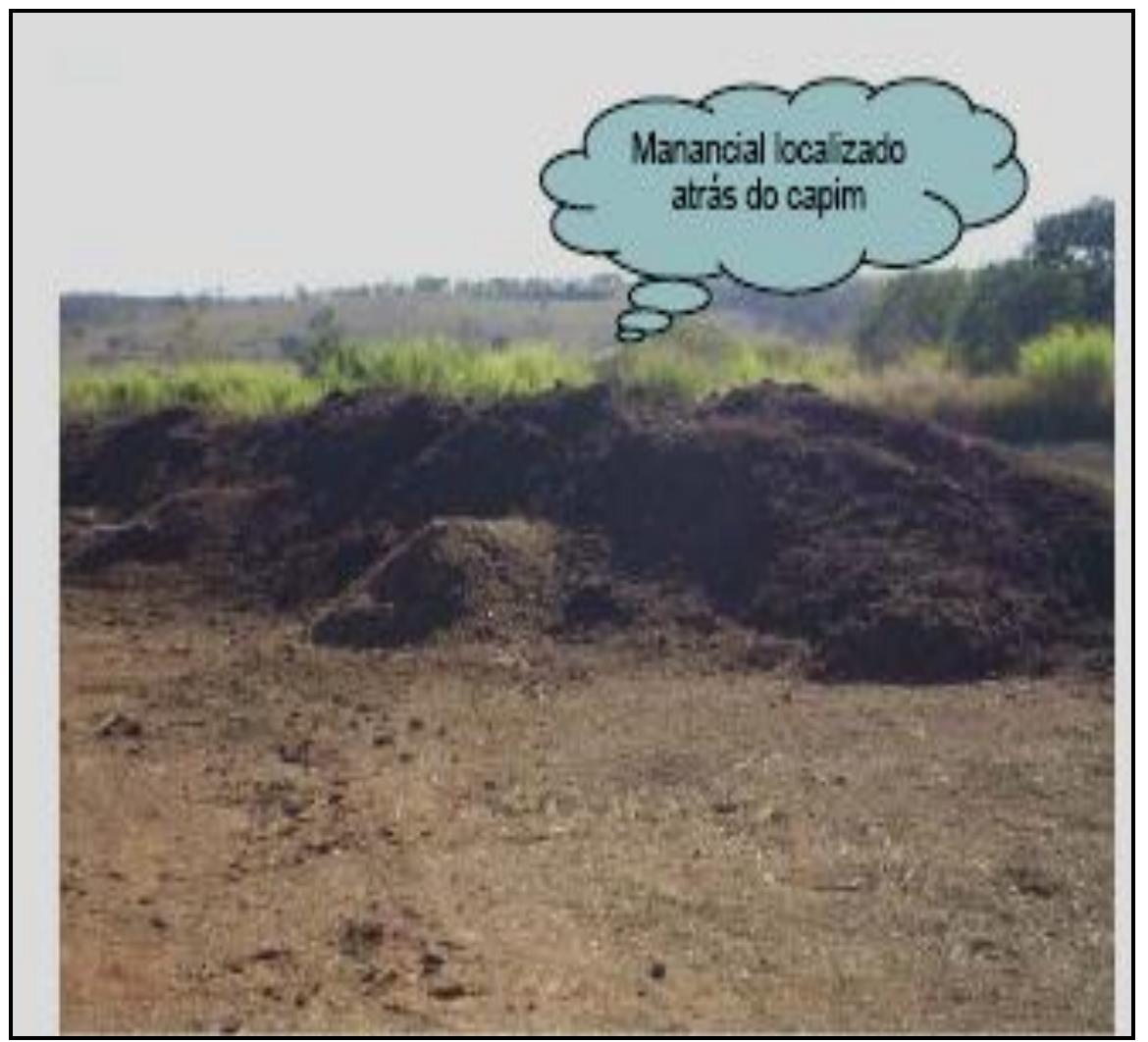

Figura 7 - Resíduo disposto no solo

Fonte: Elaboração própria

Assim, esta grande quantidade de resíduos orgânicos requer tratamento correto para reduzir a poluição e a contaminação local.

Usar digestores anaeróbicos para processar estes resíduos orgânicos torna-se uma opção atrativa, uma vez que o processo de digestão anaeróbia pode estabilizá-los biologicamente e produzir biogás para fins energéticos. 0 biogás pode ser usado como uma fonte de combustível renovável para produzir eletricidade e calor.

É sabido que em um confinamento de 100 vacas, um biodigestor pode produzir um volume de $118 \mathrm{~m}^{3}$ de biogás. Este volume é suficiente para 0 funcionamento de um grupo gerador de $15 \mathrm{kVA}$ e atender, com energia elétrica, a demanda da ordenhadeira, do resfriador de leite, do triturador, do desintegrador, do misturador de ração e da bomba d'água. A demanda total de biogás do grupo gerador para funcionar estes equipamentos foi estimada em $85,3 \mathrm{~m}^{3}$ de biogás, o que pode ser suprido com folga pelo biodigestor 
(HARDOIM \& GONÇALVES, 2000). Nas figuras 8 e 9 observa-se, respectivamente, o resfriador e ordenhadeira de leite em uma das fazendas visitadas.

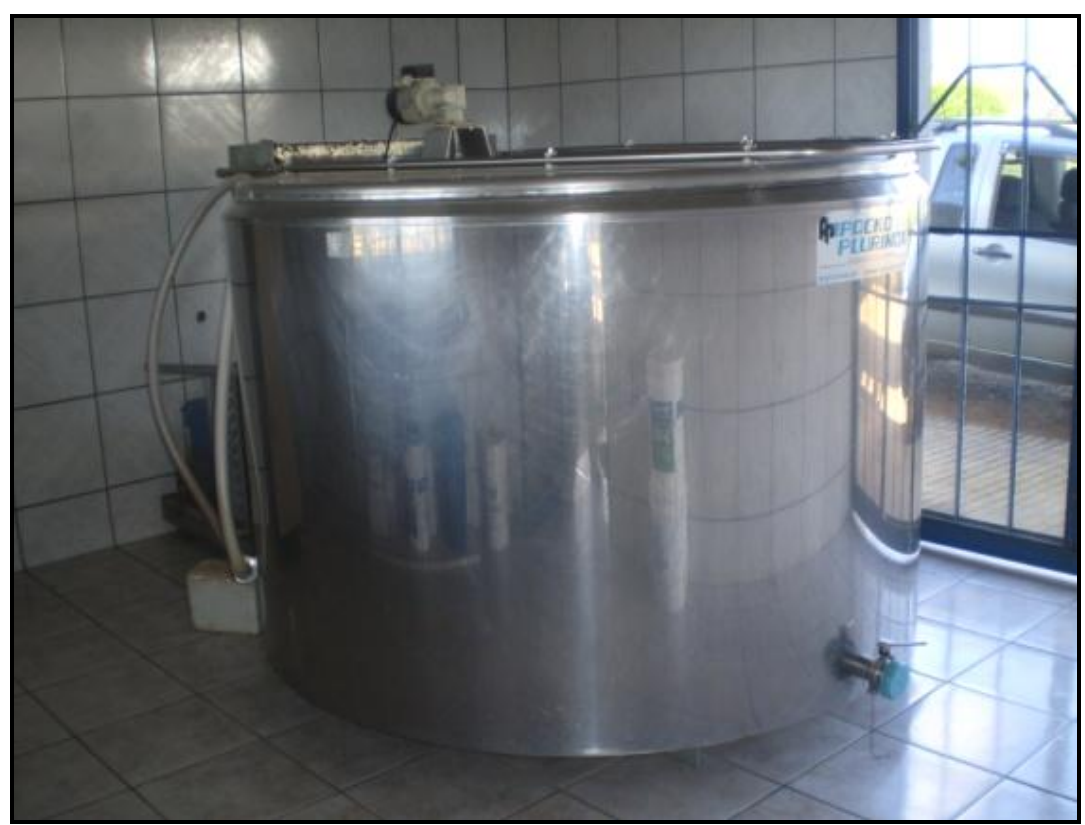

Figura 8- Resfriador de leite

Fonte: Elaboração própria

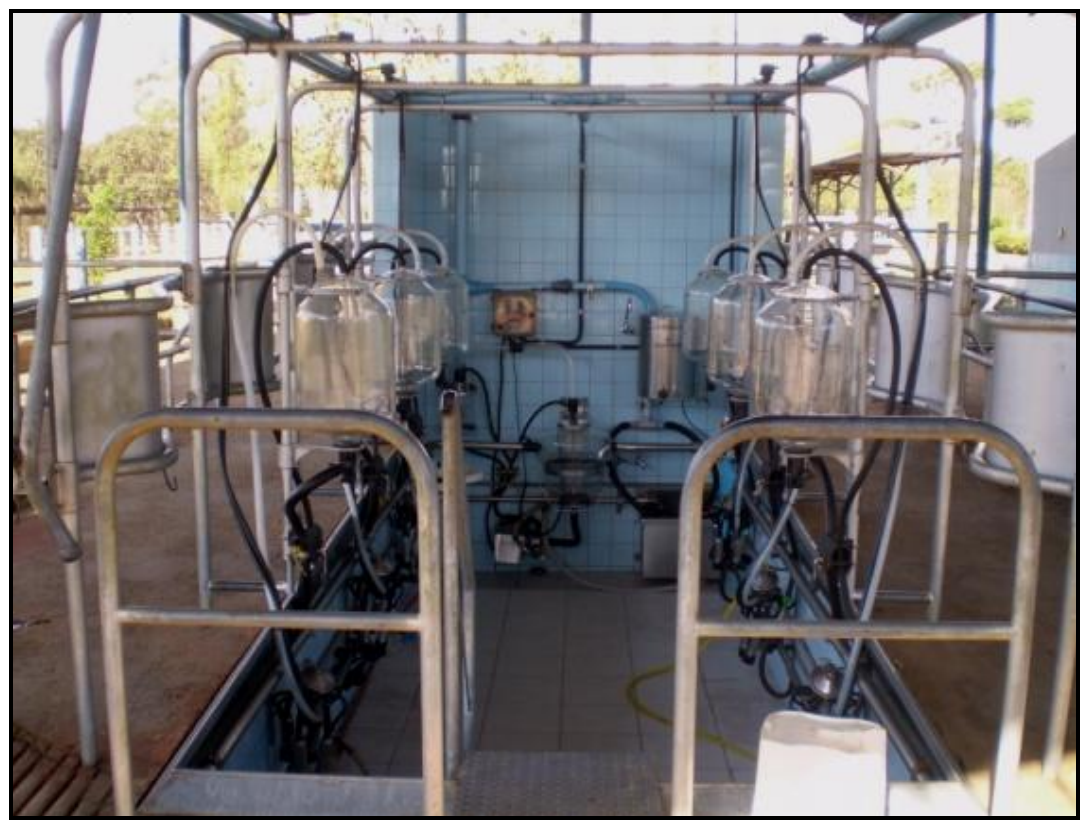

Figura 9- Ordenhadeira

Fonte: Elaboração própria 


\section{METODOLOGIA}

Para este estudo realizaram-se trabalhos de campo, tanto para conhecer as fazendas produtoras de leite, principalmente as que possuem rebanho significante de gado, como para conhecer os aspectos ambientais das propriedades e seu entorno. Foram visitadas nove fazendas e aplicou-se um questionário, conforme o modelo apresentado na figura 10, a cada uma delas para se coletar dados de relevância energética e ambiental. Coletaram-se amostras dos resíduos em todas as fazendas visitadas.

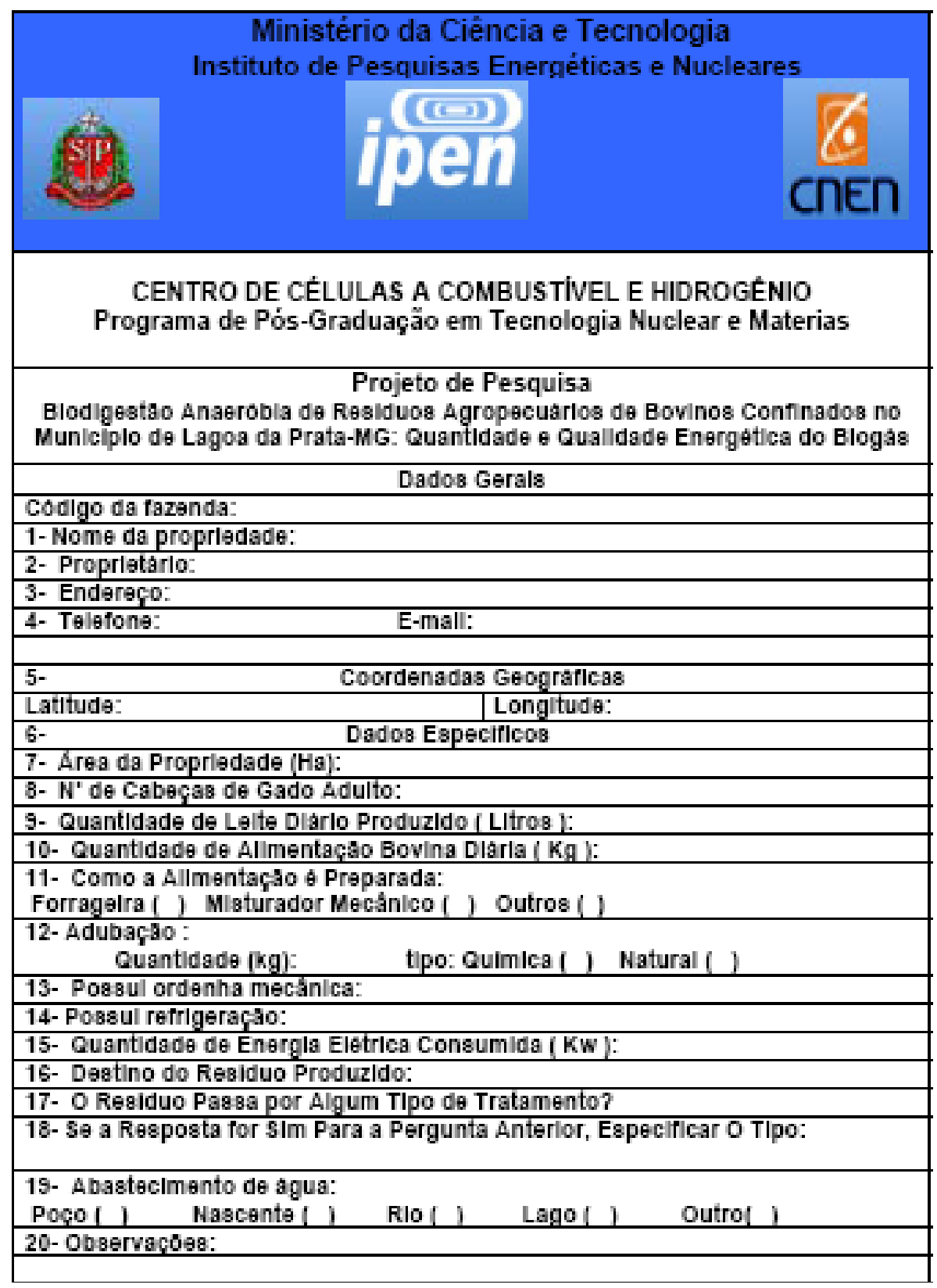

Figura 10- Questionário aplicado em campo

Fonte: Elaboração própria 
Para facilitar a identificação e localização das fazendas foi utilizado aparelho de GPS do tipo Garmim para coletar as coordenadas geográficas.

No laboratório de Geoprocessamento do Instituto de Geociências da Universidade de São Paulo foram elaborados os mapas e tabulados os geodados com o software Arc Gis 9.0 da Esri.

Foram realizadas pesquisas sobre o tema em órgãos públicos correlacionados ao eixo da pesquisa.

\subsection{Análises Químicas dos Resíduos}

Nos laboratórios do IPEN foram realizados os seguintes ensaios e experimentos como os resíduos provenientes das fazendas:

\subsection{1- Teor de umidade}

Verificou-se o teor de umidade colocando as amostras em cadinho e levando à estufa, a $100^{\circ} \mathrm{C}$ até peso constante.

\subsection{2- Sólidos Totais}

Foi verificado o percentual de sólidos totais nas amostras através de queima

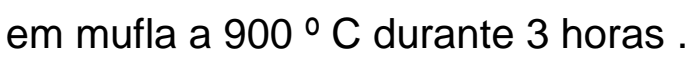

Estas etapas estão representadas nas figuras 11 e 12. 


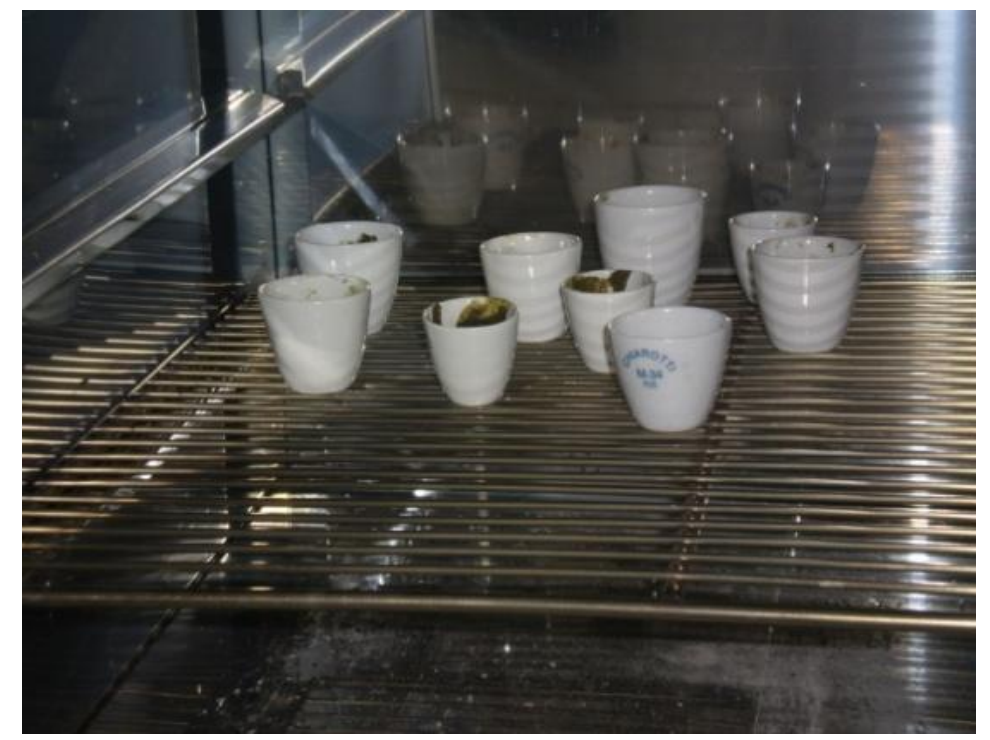

Figura 11- Amostras preparadas para secagem em estufa Fonte: Elaboração própria

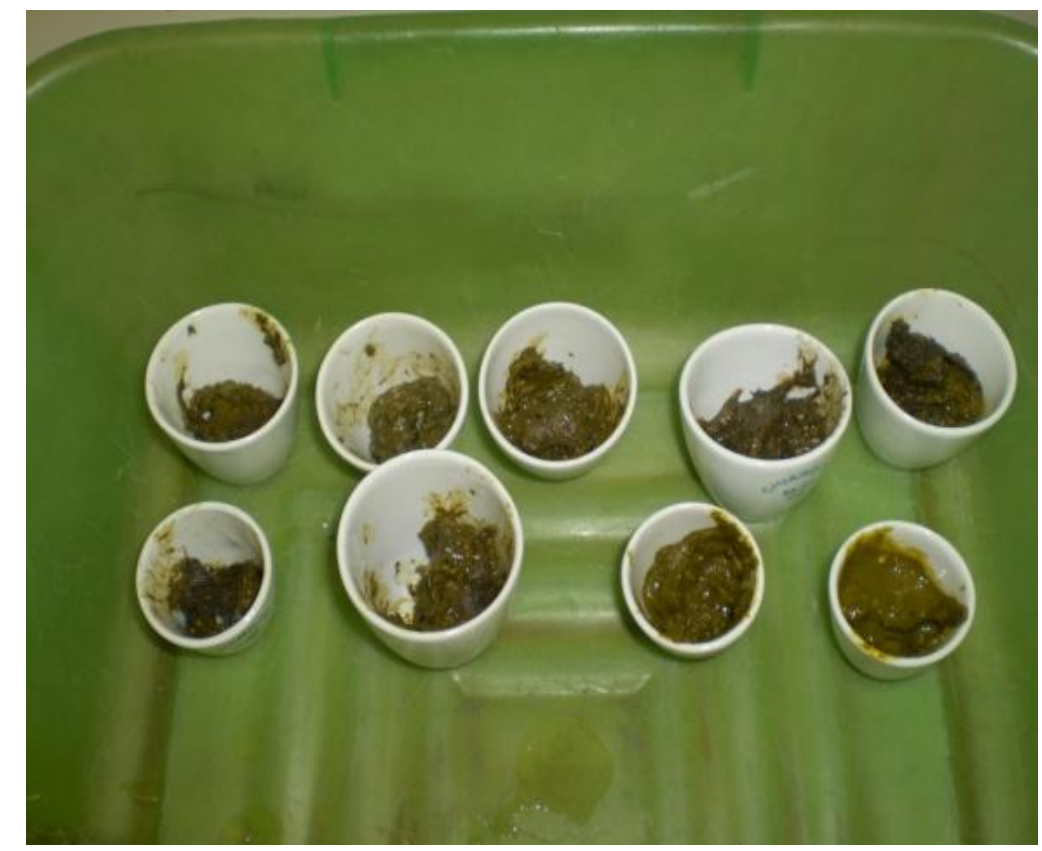

Figura 12- Amostra para queima em mufla Fonte: Elaboração própria

- Foram construídos nove protótipos de biodigestores do tipo batelada, correspondentes às nove fazendas visitadas, para simular a biodigestão dos resíduos e verificar a composição química do biogás 
obtido. Nestes ensaios os resíduos permaneceram nos biodigestores por 60 dias dos quais, a cada dez dias, mediram-se $0 \mathrm{pH}$ e temperatura e coletaram-se amostras de biogás para análises químicas. Na figura 13 apresenta-se o biodigestor utilizado nas experiências e na figura 14 a realização da coleta do biogás.

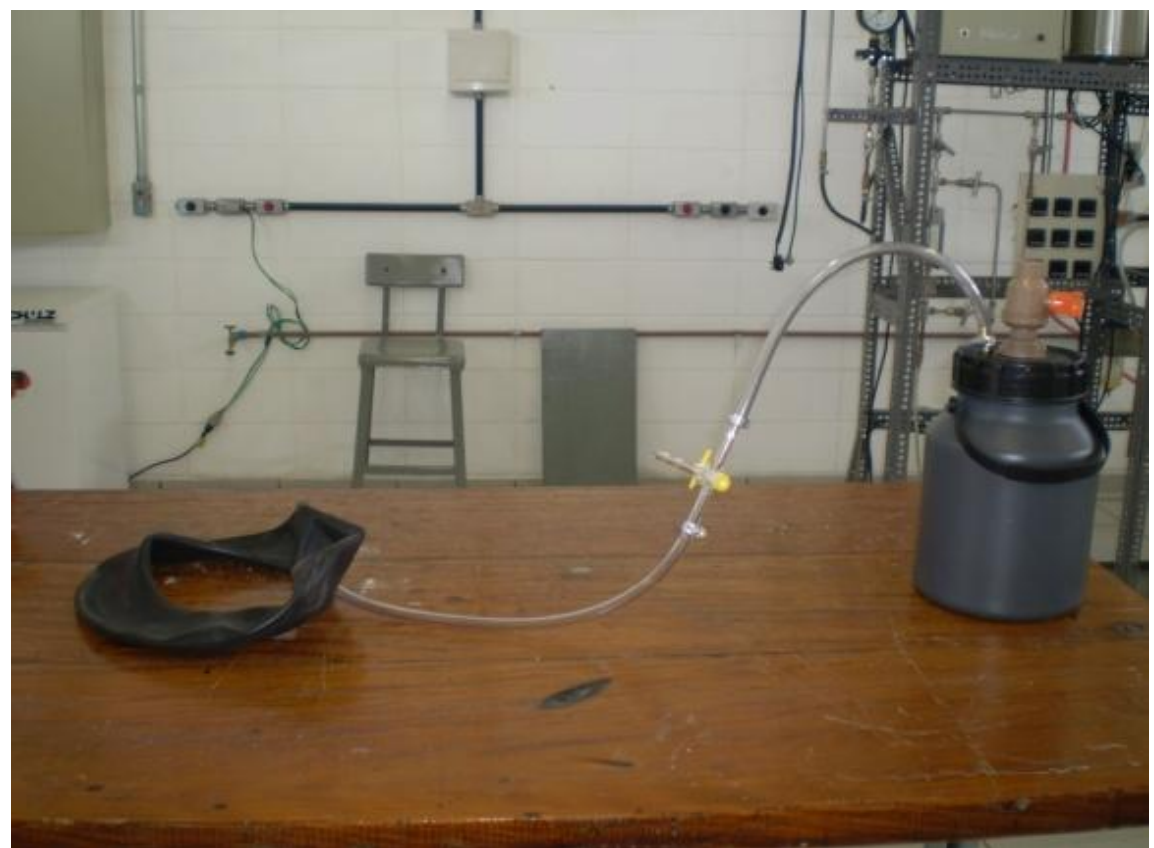

Figura 13: Detalhes do biodigestor

Fonte: Elaboração própria 


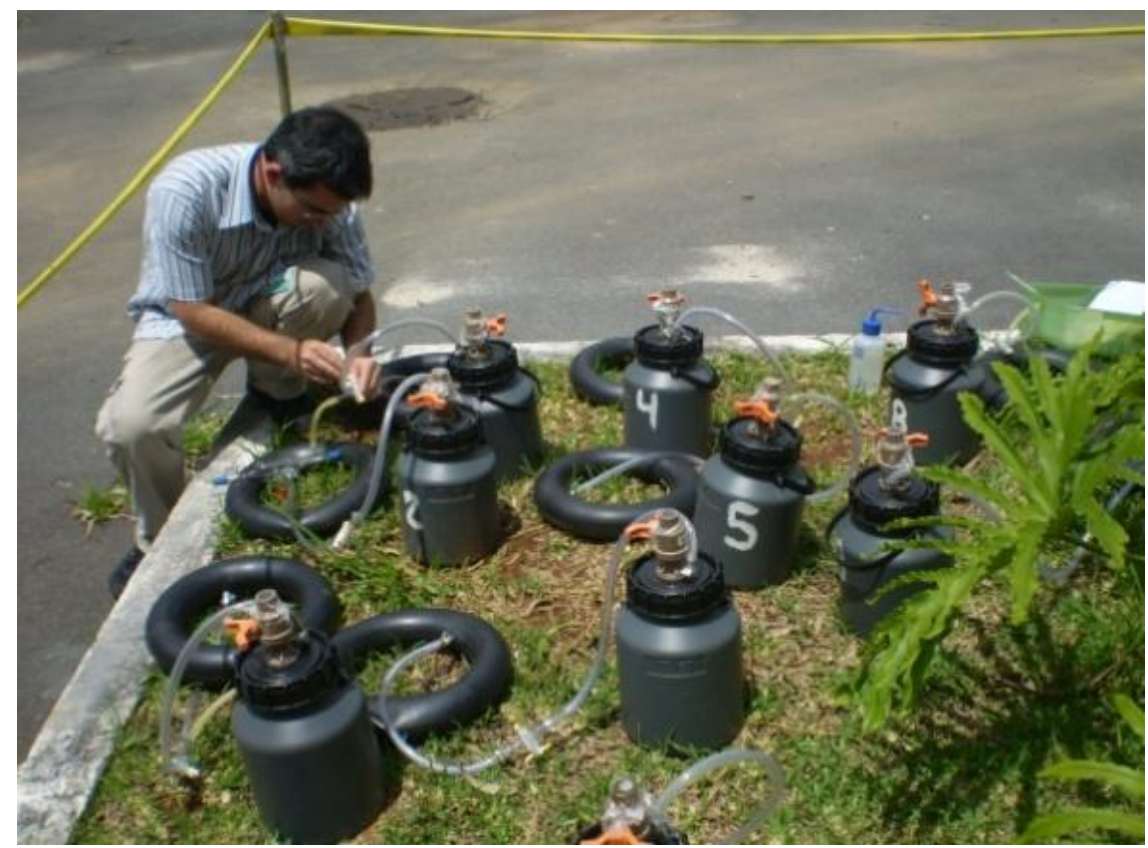

Figura 14: Coleta de biogás nos biodigestores Fonte: Elaboração própria

- Para verificar a composição química do biogás foram realizados cinco ensaios de cromatografia gasosa no Cromatógrafo a gás marca Agilent Technologies, Modelo: 7890A - GC para todos os biodigestores durante o tempo de retenção de 60 dias. Na figura 15 observa-se o momento de injeção da amostra no cromatógrafo.

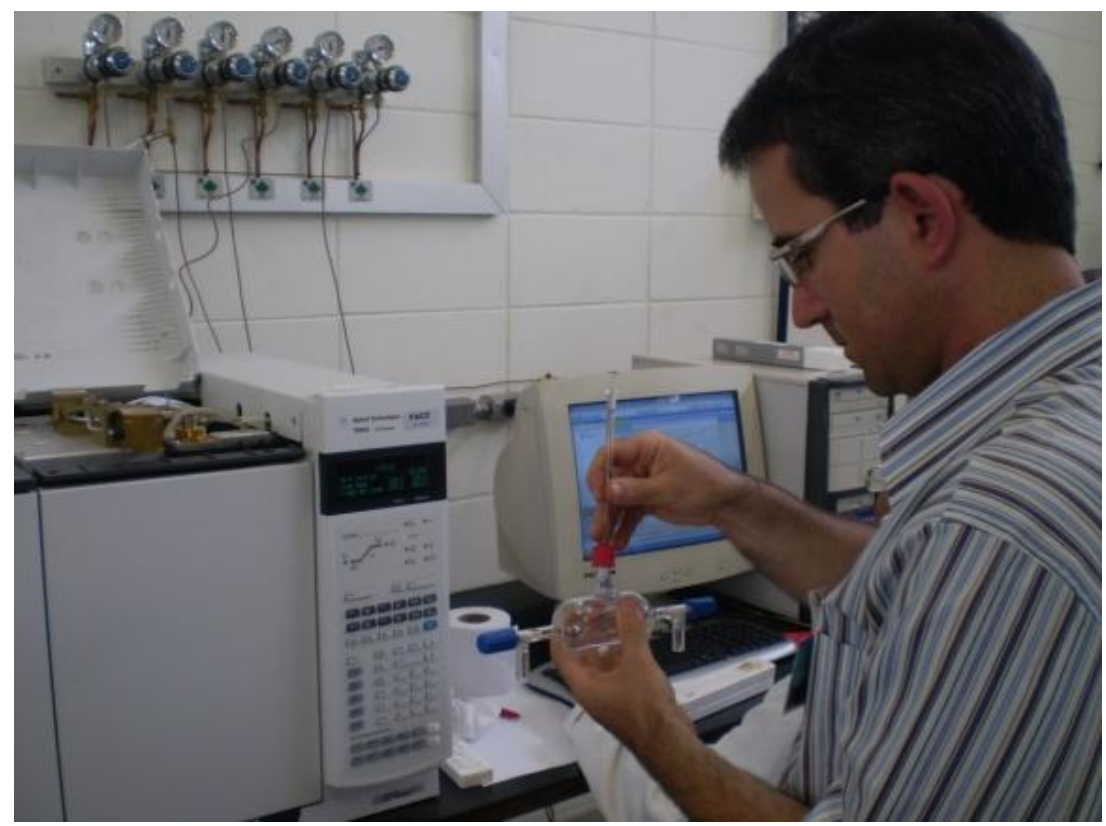

Figura 15: Injeção de biogás no cromatógrafo a gás Fonte: Elaboração própria 
- Realizaram-se análises químicas por Espectometria de Fluorescência por Raios-X (WDXRF) dos óxidos obtidos na calcinação dos resíduos para identificação de possíveis elementos químicos poluentes. $\mathrm{Na}$ figura 16 apresentam-se as amostras preparadas para as análises.

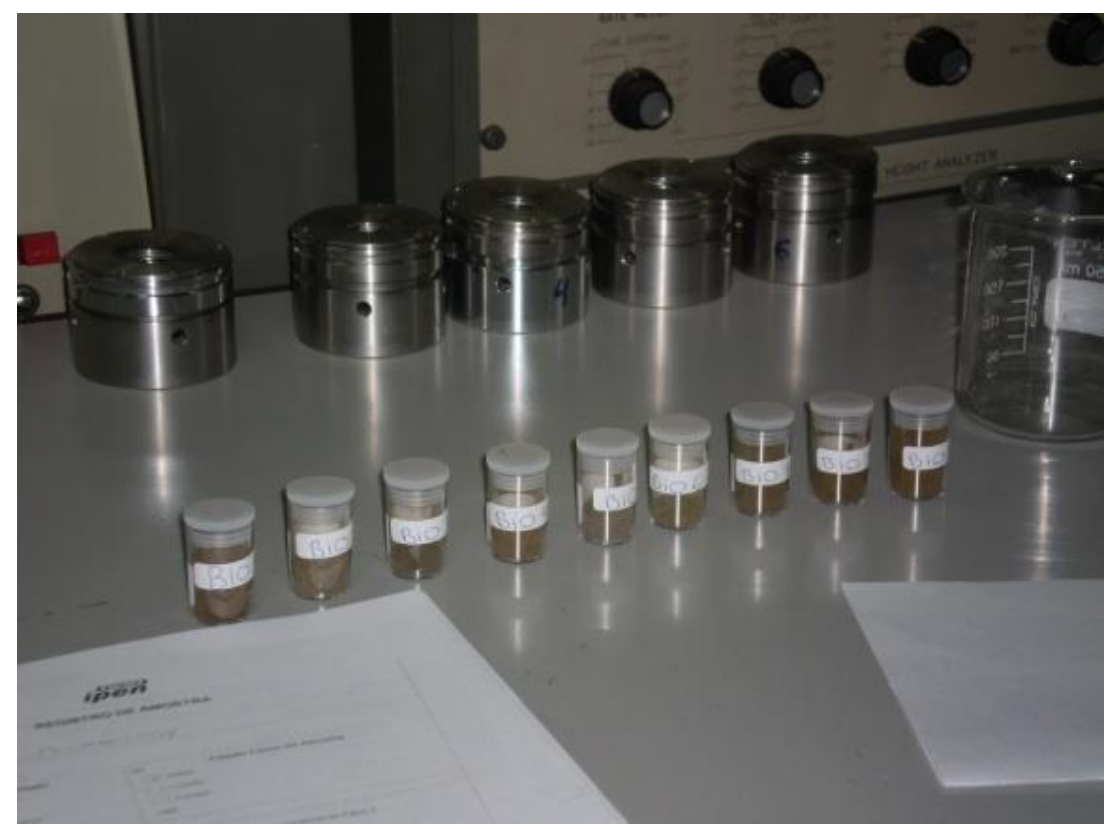
raio $\mathrm{x}$

Figura 16: Amostras para serem analisadas na florescência de Fonte: Elaboração própria 


\section{RESULTADOS E DISCUSSÃO}

Com os dados obtidos em campo através do questionário aplicado, conforme figura 10, pôde-se notar a dimensão da problemática da pecuária leiteira no município de Lagoa da Prata. Na tabela 6 podem-se observar alguns dados de relevância ambiental obtidos em campo.

Tabela 6- Dados de relevância ambiental obtidos em campo

\begin{tabular}{|l|c|c|c|c|}
\hline \multicolumn{5}{|c|}{ DADOS DE RELEVÂNCIA AMBIENTAL OBTIDOS EM } \\
CAMPO \\
\hline Propriedades & $\begin{array}{c}\text { Área } \\
\text { (ha) }\end{array}$ & $\begin{array}{c}\text { Cabeças } \\
\text { de Gado }\end{array}$ & $\begin{array}{c}\text { Resíduos } \\
\text { (Kg/dia) }\end{array}$ & $\begin{array}{c}\text { Consumo } \\
\text { de água } \\
\text { ( } \mathbf{m}^{3} / \text { dia) }\end{array}$ \\
\hline Fazenda 01 & 160 & 470 & 7.000 & 30 \\
\hline Fazenda 02 & 65 & 165 & 2.500 & 30 \\
\hline Fazenda 03 & 259 & 265 & 4.000 & 30 \\
\hline Fazenda 04 & 24,5 & 80 & 1.200 & 20 \\
\hline Fazenda 05 & 300 & 140 & 2.100 & 20 \\
\hline Fazenda 06 & 210 & 300 & 4.500 & 30 \\
\hline Fazenda 07 & 27 & 90 & 1.350 & 30 \\
\hline Fazenda 08 & 98 & 150 & 2.250 & 30 \\
\hline Fazenda 09 & 230 & 200 & 3.000 & 30 \\
Total & 1143,5 & 1860 & 27.900 & 250 \\
\hline
\end{tabular}

Observa-se o quanto é expressivo o volume de resíduos gerados diariamente pelo rebanho nas fazendas estudadas na região de Lagoa da 
Prata, em MG, cujas localizações podem ser observadas na figura 17 e que são dispostos sem qualquer tratamento prévio no solo. A quantidade de água consumida também é grande, pois como 0 rebanho se alimenta constantemente com rações ricas em sais, isso faz com que as vacas bebam muita água no decorrer do dia, eliminando-a junto com os resíduos. Isso torna a consistência do resíduo ideal para ser canalizado a um biodigestor próximo aos currais e ser biodigerido, gerar biogás, biofertilizante e consequentemente tratar os resíduos. 


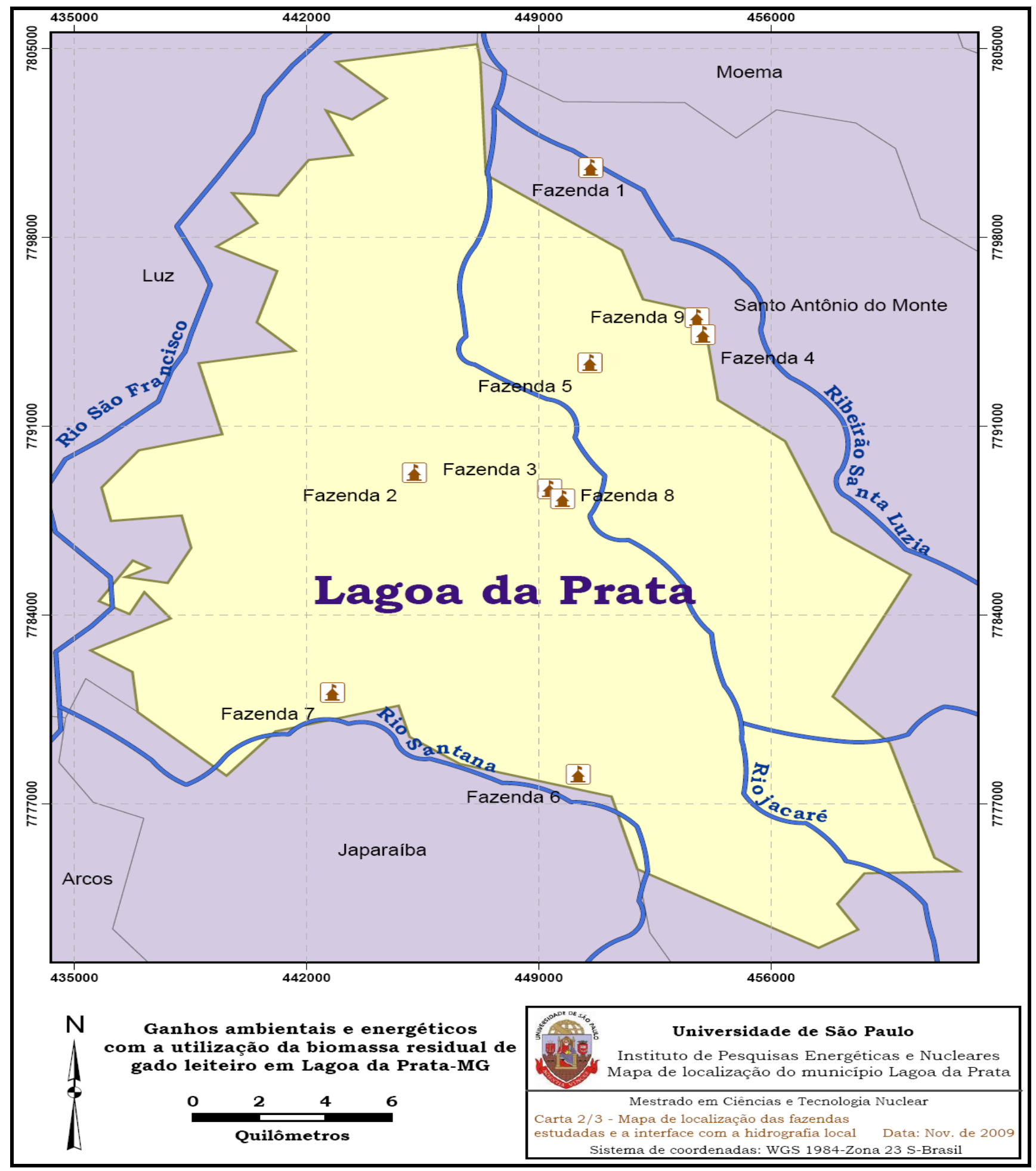

Figura 17: Mapa de localização das fazendas estudadas

Fonte: Flávio soares de oliveira

Pode-se observar que as fazendas estão próximas a rios que são tributários do Rio São Francisco. Diante da proximidade com os recursos hídricos, os resíduos depositados no solo estão sujeitos a serem carreados 
para os rios, sendo que o chorume irá percolar para as águas subterrâneas alterando, assim, a qualidade das águas e comprometendo a bacia hidrográfica do Rio São Francisco naquela região.

O gerenciamento dos resíduos de forma inadequada poderá acarretar poluição hídrica, pois estes resíduos são ricos em fósforo e nitrogênio, principais nutrientes de aporte da eutrofização e ao mesmo tempo aumentar a Demanda Bioquímica de Oxigênio dos mesmos, comprometendo o Índice de Qualidade das Águas, IQA, na região.

\subsection{Umidade nas amostras}

Os resultados dos ensaios para determinar a umidade dos resíduos das fazendas estudadas são apresentados na tabela 7.

Tabela 7- Determinação de umidade

\begin{tabular}{|c|c|c|c|c|c|c|c|c|}
\hline \multicolumn{9}{|c|}{ Peso do Resíduo Fresco em Gramas ( g ) } \\
\hline Amostra 01 & Amostra 02 & Amostra 03 & Amostra 04 & Amostra 05 & Amostra 06 & Amostra 07 & Amostra 08 & Amostra 09 \\
\hline $4.6735 \mathrm{~g}$ & $6,570 \mathrm{~g}$ & $8.5955 \mathrm{~g}$ & $9.1576 \mathrm{~g}$ & $11.8208 \mathrm{~g}$ & $8.4506 \mathrm{~g}$ & $4.8938 \mathrm{~g}$ & $6.4444 \mathrm{~g}$ & $7.5792 \mathrm{~g}$ \\
\hline \multicolumn{9}{|c|}{ Peso Constante do Resíduo em Gramas ( g ) } \\
\hline Amostra 01 & Amostra 02 & Amostra 03 & Amostra 04 & Amostra 05 & Amostra 06 & Amostra 07 & Amostra 08 & Amostra 09 \\
\hline $3.8532 \mathrm{~g}$ & $5.6392 \mathrm{~g}$ & $7.3163 \mathrm{~g}$ & $7.9177 \mathrm{~g}$ & $10.0395 \mathrm{~g}$ & $7.2146 \mathrm{~g}$ & $3.6818 \mathrm{~g}$ & $5.5196 \mathrm{~g}$ & $6.701 \mathrm{~g}$ \\
\hline \multicolumn{9}{|c|}{ \% de Umidade nos Resíduos } \\
\hline Amostra 01 & Amostra 02 & Amostra 03 & Amostra 04 & Amostra 05 & Amostra 06 & Am ostra 07 & Amostra 08 & Amostra 09 \\
\hline $17,55 \%$ & $14,16 \%$ & $14,88 \%$ & $13,53 \%$ & $15,06 \%$ & $14,62 \%$ & $24,76 \%$ & $14,35 \%$ & $11,58 \%$ \\
\hline
\end{tabular}

Pelos resultados do teor de umidade pode-se verificar que boa parte dos resíduos é composta por matéria orgânica vegetal e minerais. Contudo, para a biodigestão ocorrer com alta produtividade de biogás seria necessário um complemento de água para chegar à composição de $75 \%$ de umidade conforme Nogueira (1986), porém há de se considerar que no ambiente de ordenha os resíduos se misturam com urina das vacas tornando os resíduos 
mais úmidos. Ademais, no processo de higienização do piso e equipamentos esta água de limpeza pode entrar na composição da biomassa para a consistência ideal. Assim, os resíduos poderão ir diretamente para um biodigestor por declividade.

\subsection{Temperaturas nos biodigestores}

Fizeram-se cinco medidas de temperatura em cada um dos biodigestores, obtendo-se uma média entre $30^{\circ} \mathrm{C}$ e $33^{\circ} \mathrm{C}$, conforme pode ser visto na figura 18.

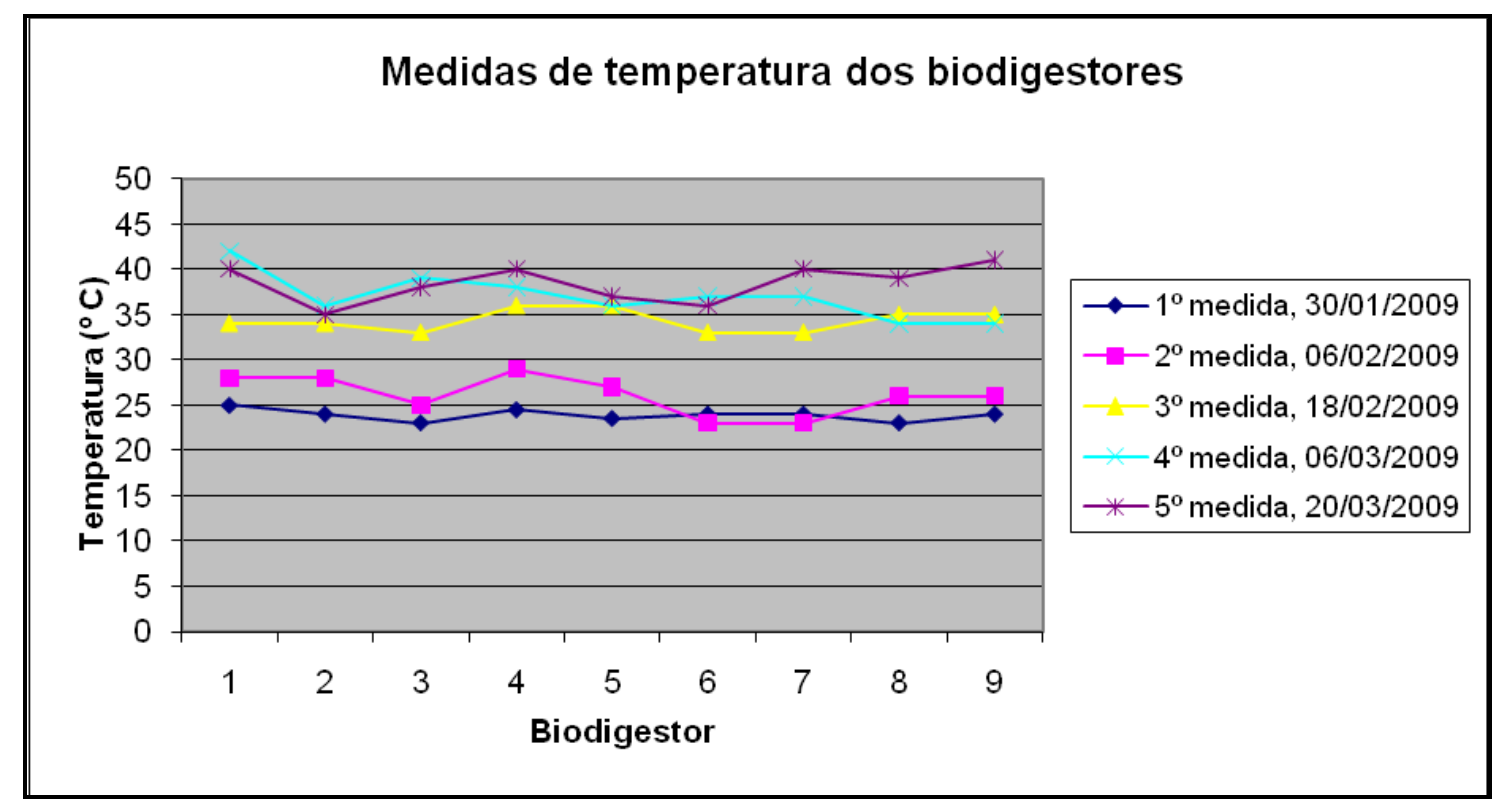

Figura 18- Medidas de temperaturas nos biodigestores

Fonte: Flávio soares de oliveira

Cabe salientar que a média ideal descrita na literatura é de $37^{\circ} \mathrm{C}$, mas ressalta-se que durante o período em que foi desenvolvido o experimento choveu bastante em São Paulo, conforme se apresenta na figura 19, o que pode ter influenciado no resfriamento dos biodigestores. 


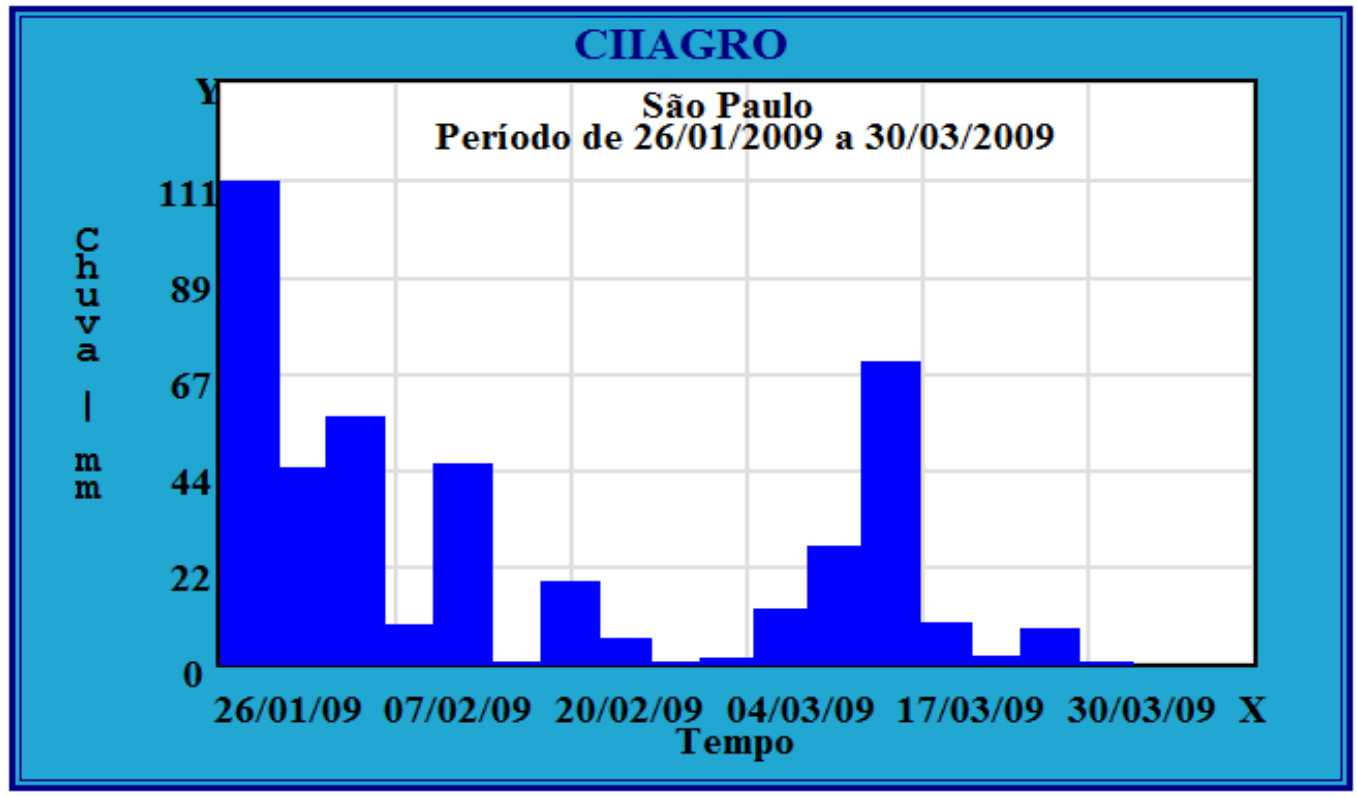

Figura 19: Pluviometria em São Paulo durante o período de realização dos ensaios. Fonte : Fonte: http://www.ciiagro.sp.gov.br/ciiagroonline acessado em 19/02/2010

Conforme o gráfico da figura 19, pode-se observar que durante o inicio do experimento, realizado na última semana de janeiro de 2009, o indice de chuvas foi bem alto, havendo um decréscimo na metade do experimento e voltando a subir, o que pode ter influenciado na temperatura do sistema. Cumpre ressaltar que há relatos na literatura que, no campo, a pluviometria pode influenciar na produção de biogás.

\section{3. $\mathrm{pH}$ dos resíduos nos biodigestores}

A média dos $\mathrm{pH}$ obtidos através de leituras com papel indicador de todos os biodigestores durante os ensaios de biodigestão manteve-se entre 5 e 6 , que está de acordo com a média indicada por Nogueira (1986) em seus estudos sobre 0 assunto. Esses índices estão apresentados na figura $20 \mathrm{e}$ representam todas as leituras realizadas no período de retenção da biomassa nos biodigestores 
Medidas de $\mathrm{pH}$ nos Biodigestores
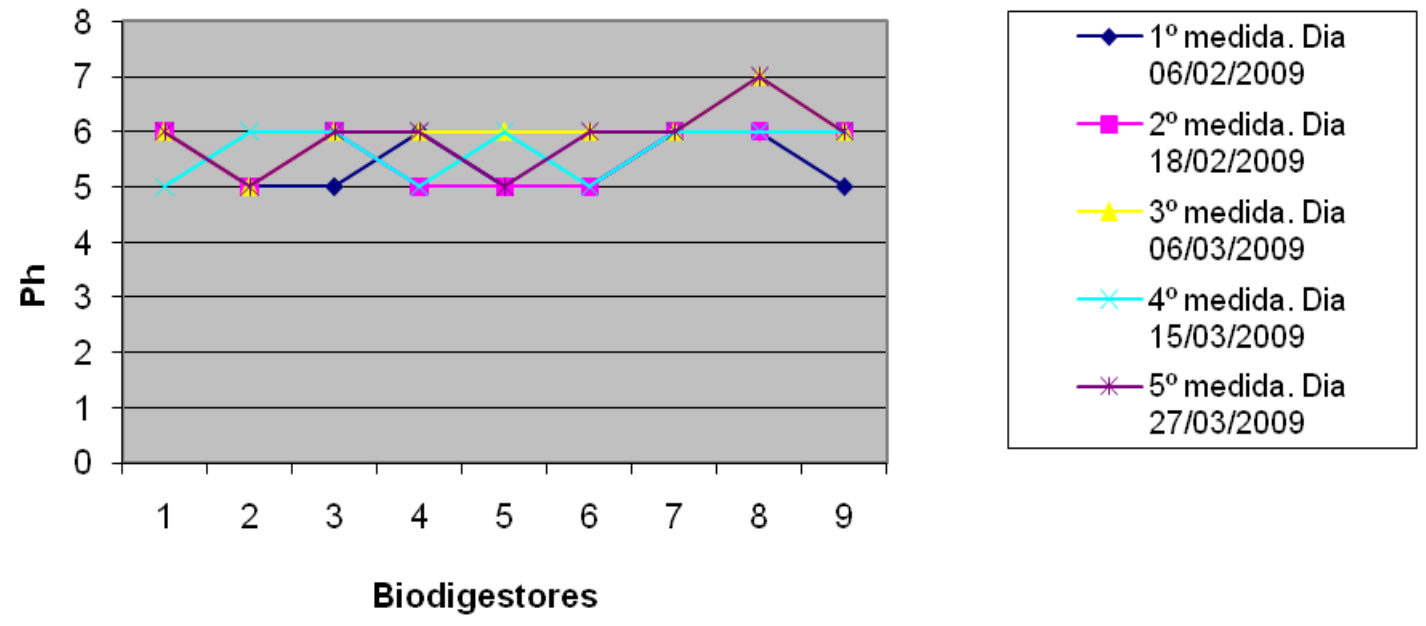

Figura 20- Leituras de pH nos biodigestores

Fonte: Elaboração própria

\subsection{Cromatografia Gasosa}

Com as análises de cromatografia gasosa realizadas durante o período de janeiro a março de 2009, determinaram-se os teores dos gases $\mathrm{CH}_{4}, \mathrm{CO}_{2}$, $\mathrm{O}_{2}$ e $\mathrm{N}_{2}$. Fizeram-se 5 medidas para cada biodigestor. Nas figuras de 21 a 29 apresentam-se as médias destas análises para os nove biodigestores. 


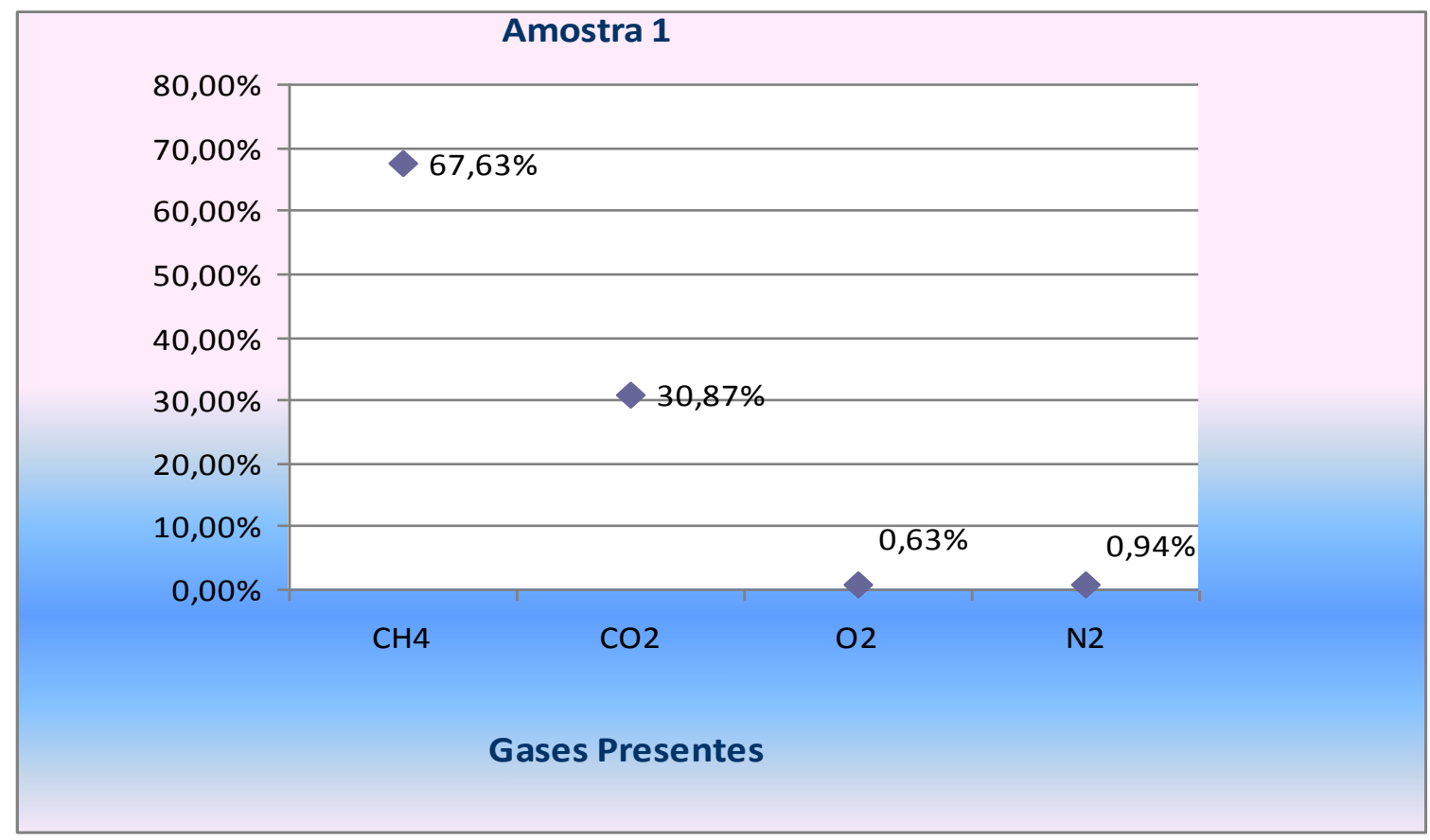

Figura 21- Percentuais de gases obtidos no biogás da amostra1 através de cromatografia gasosa

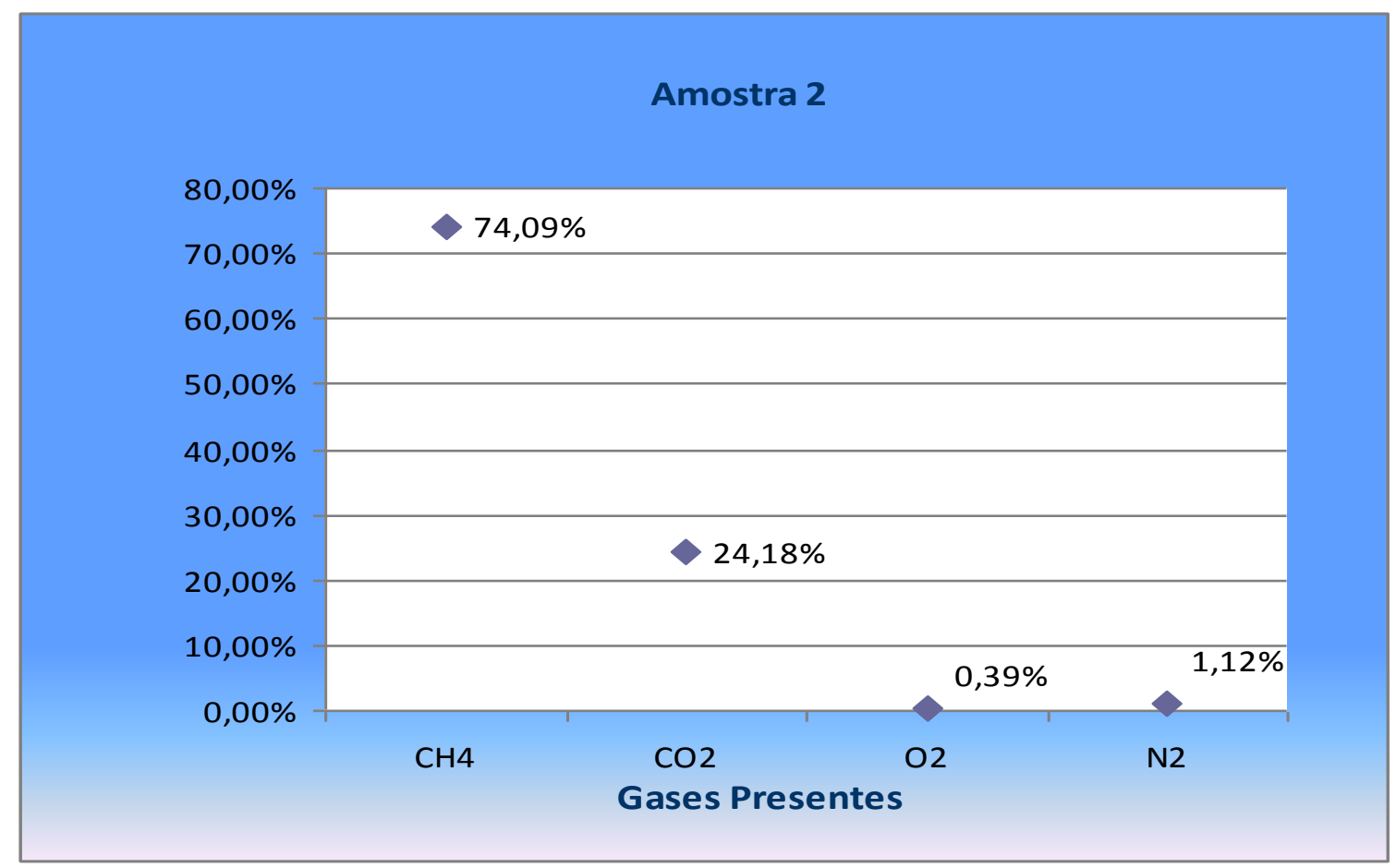

Figura 22- Percentuais de gases obtidos no biogás da amostra 2 através de cromatografia gasosa 
Amostra 3

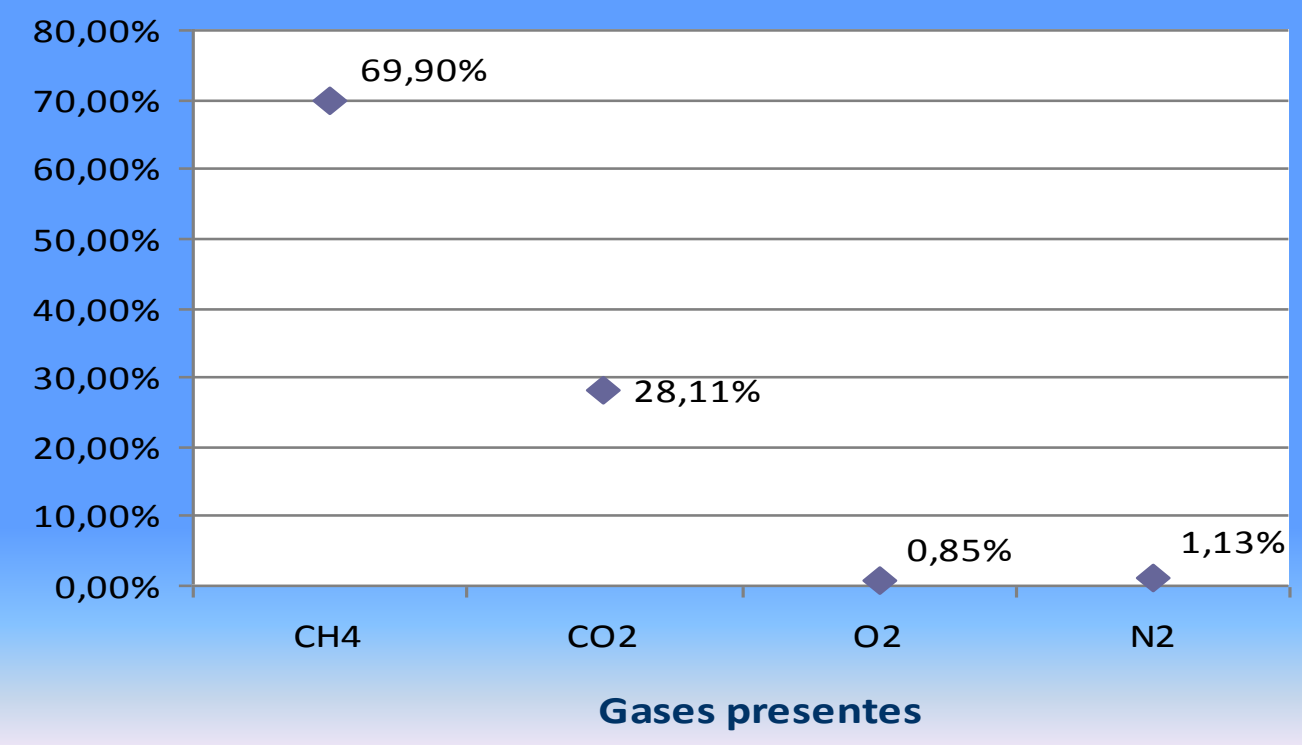

Figura 23- Percentuais de gases obtidos no biogás da amostra 3 através de cromatografia gasosa

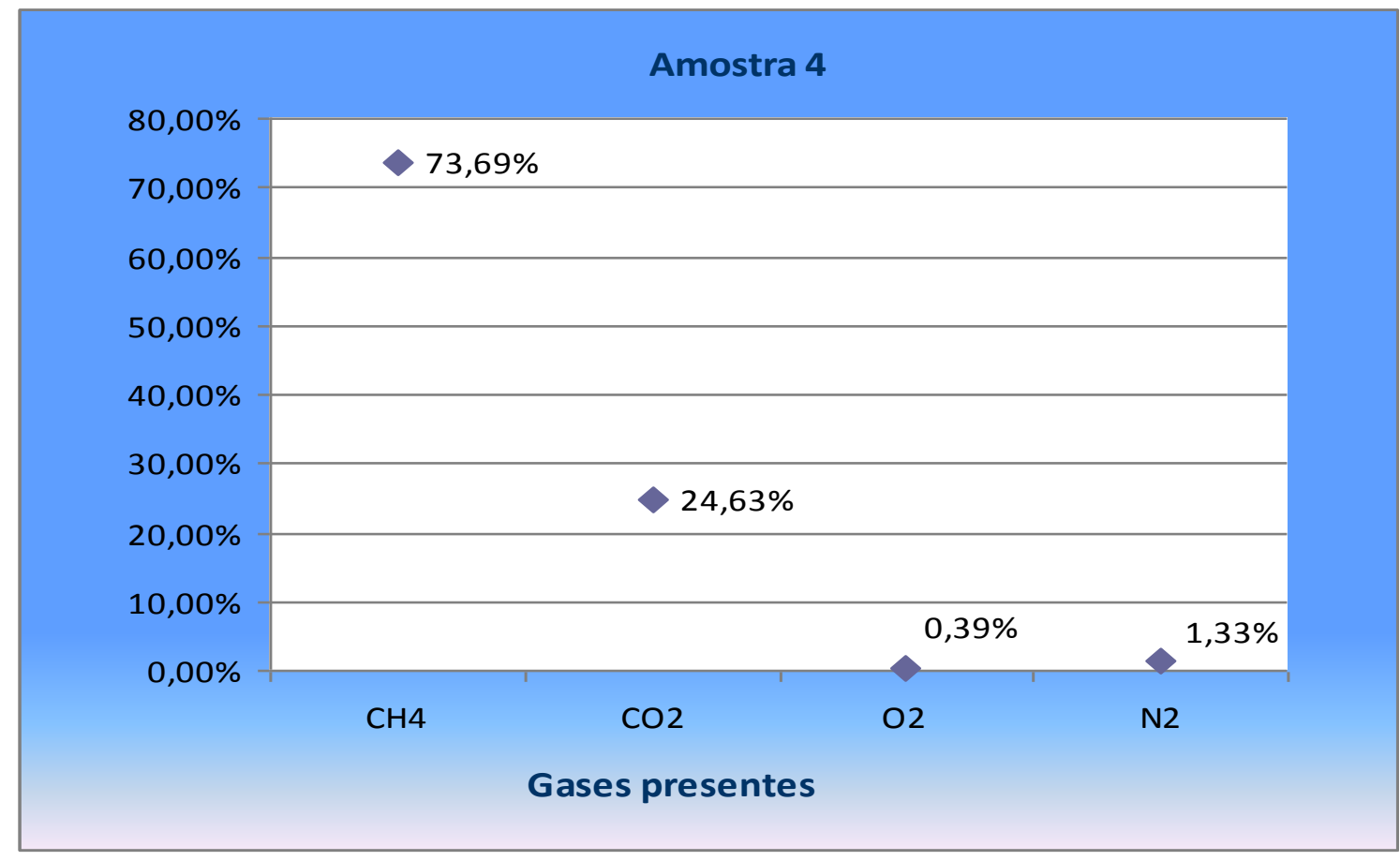

Figura 24- Percentuais de gases obtidos no biogás da amostra 4 através de cromatografia gasosa 
Amostra 5

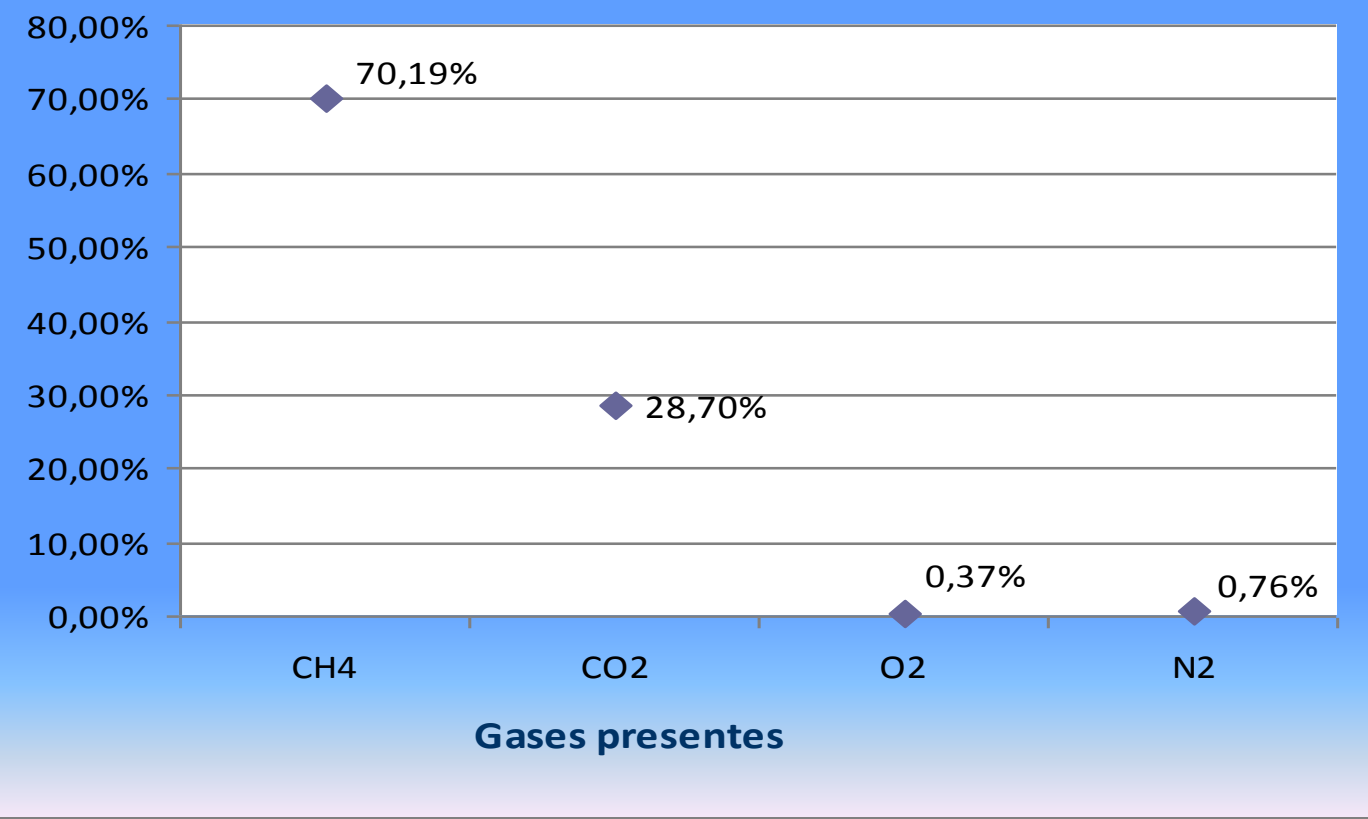

Figura 25- Percentuais de gases obtidos no biogás da amostra 5 através de cromatografia gasosa

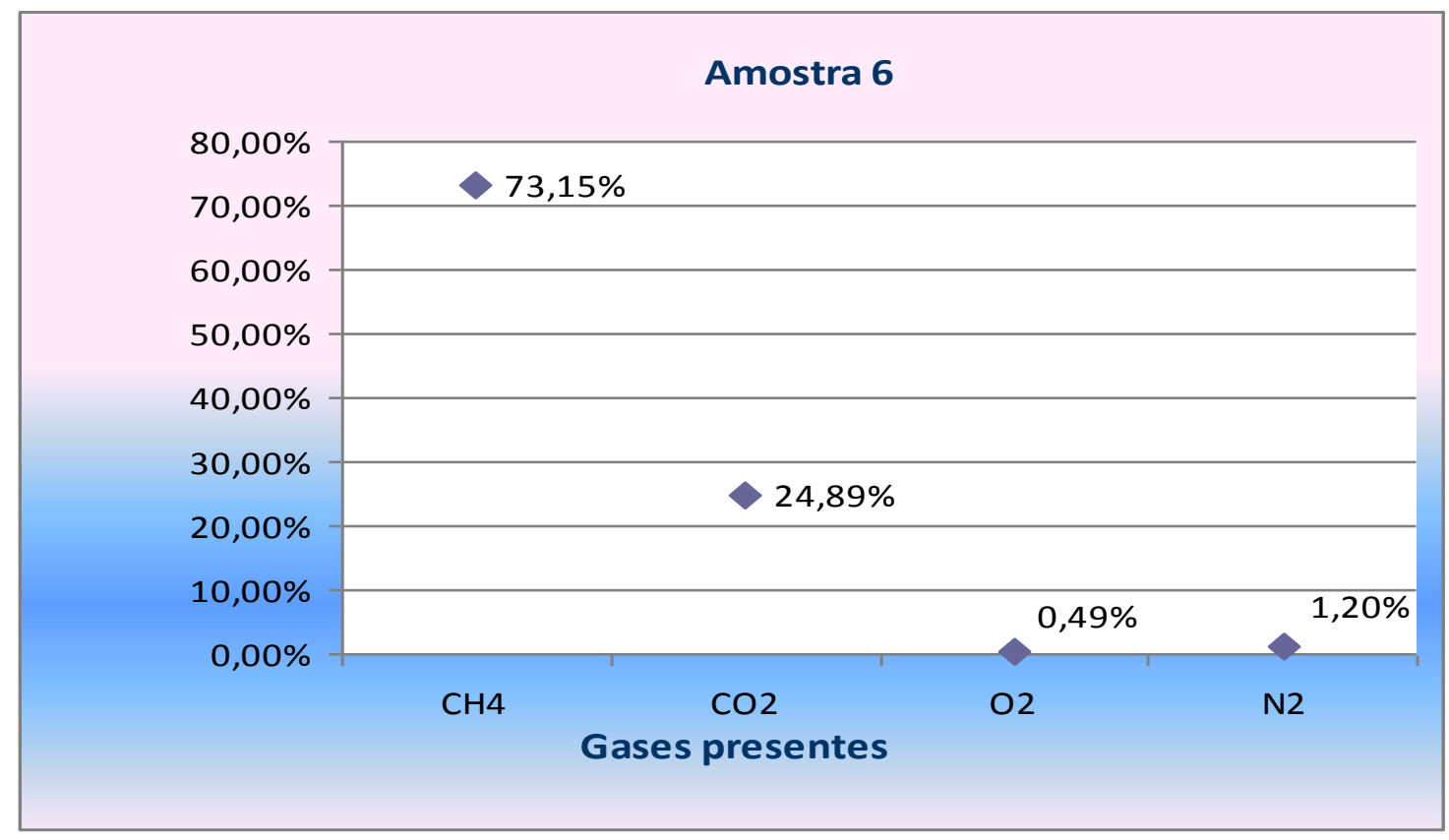

Figura 26- Percentuais de gases obtidos no biogás da amostra 6 através de cromatografia gasosa 


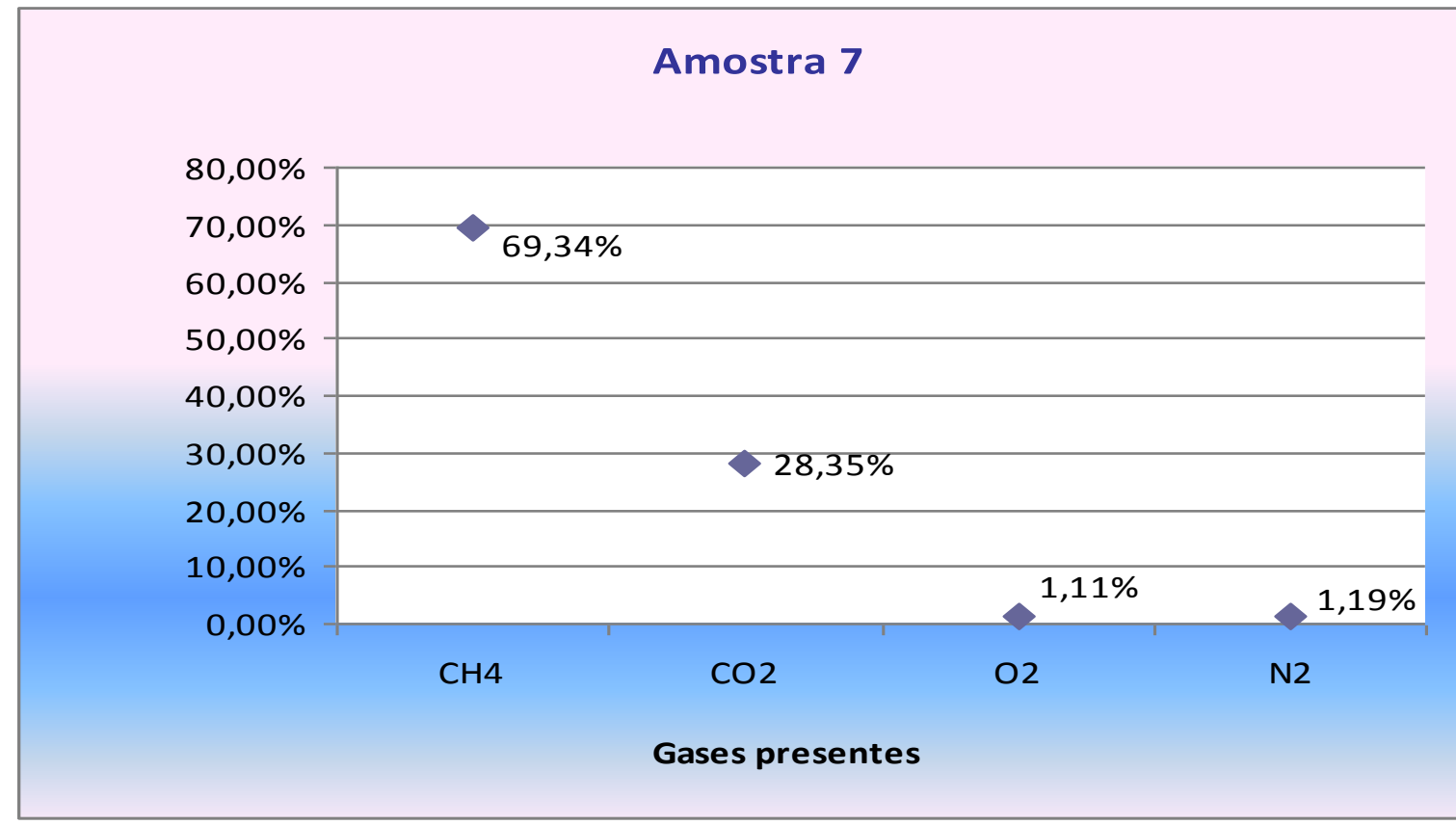

Figura 27- Percentuais de gases obtidos no biogás da amostra 7 através de cromatografia gasosa

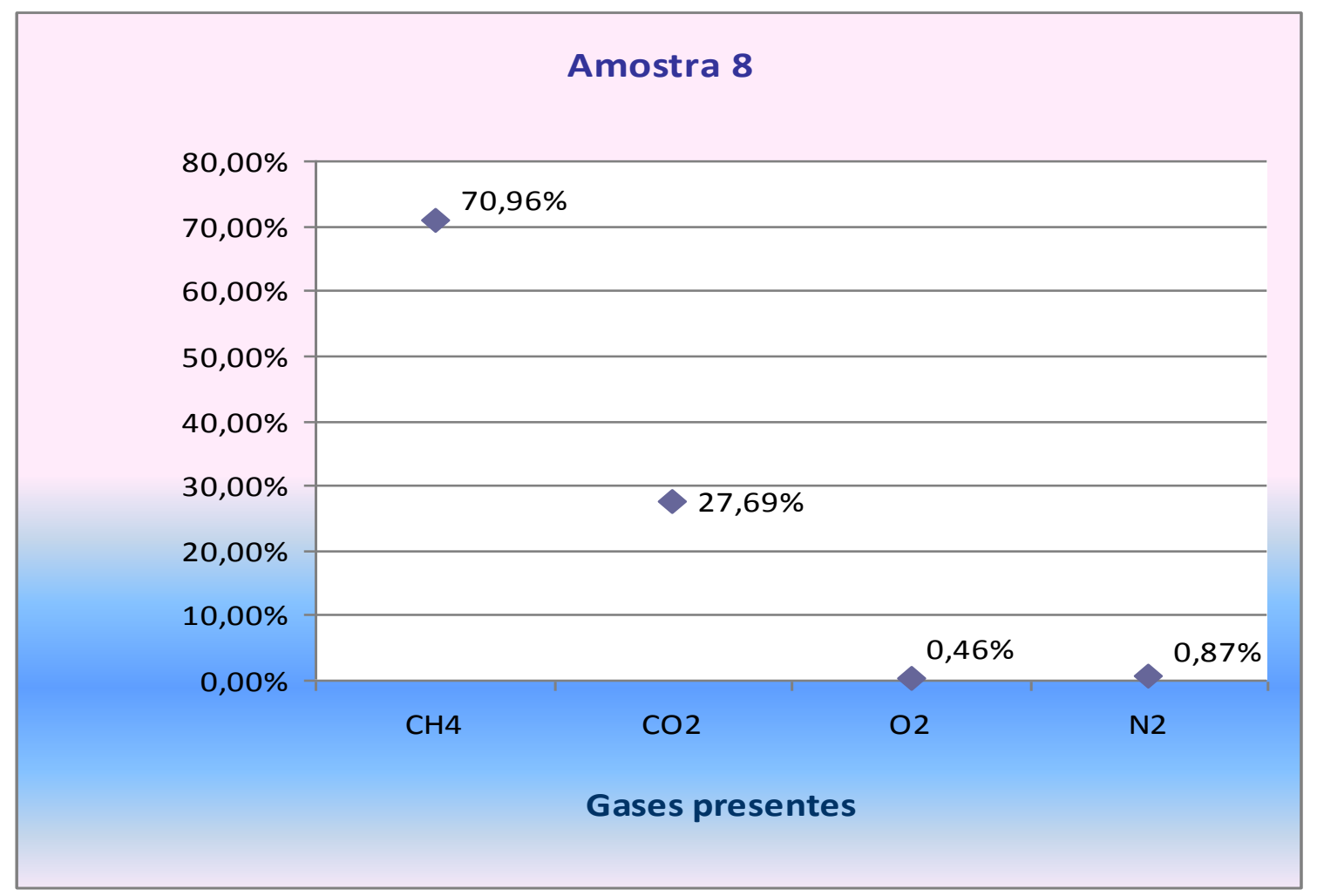

Figura 28- Percentuais de gases obtidos no biogás da amostra 8 através de cromatografia gasosa 


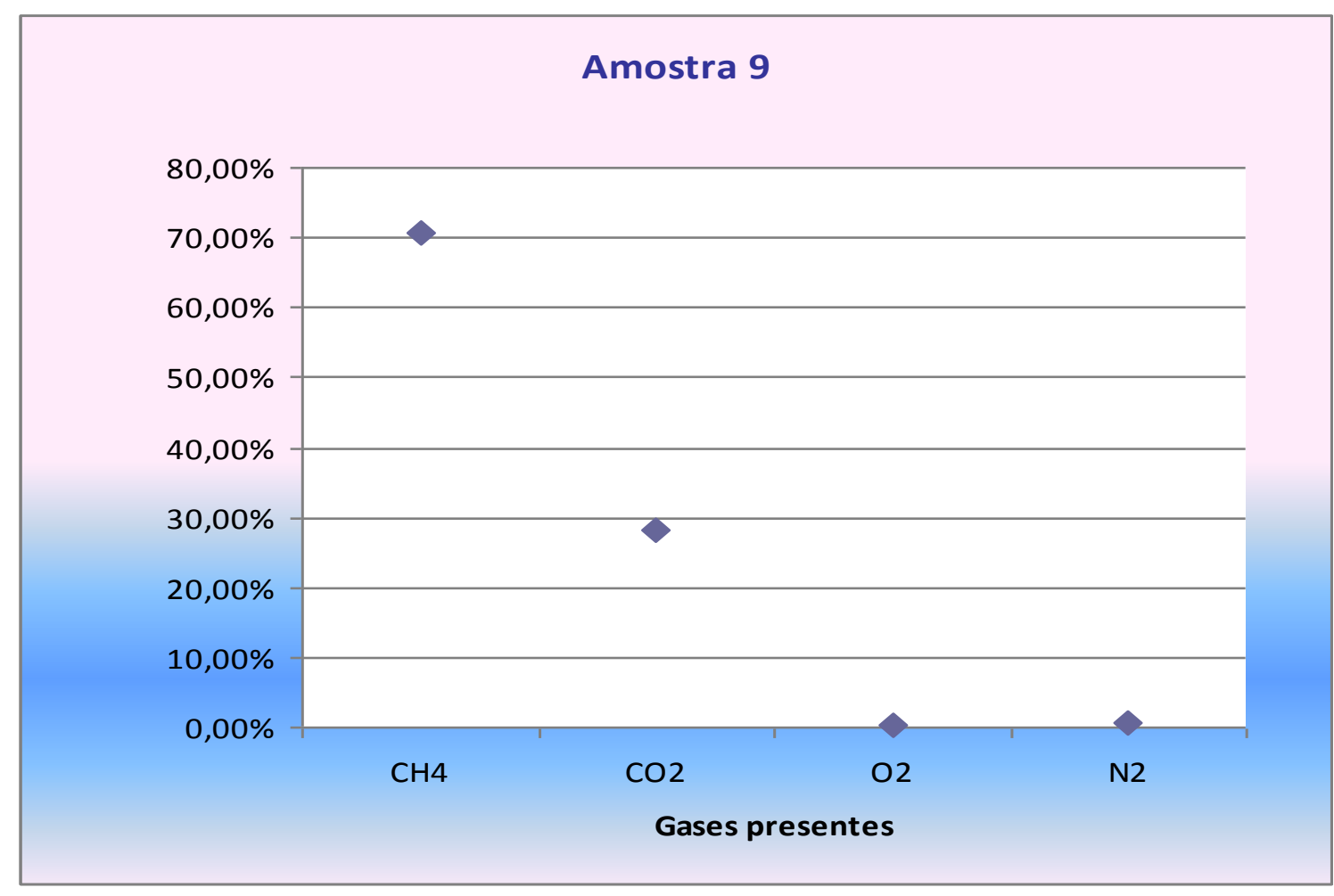

Figura 29- Percentuais de gases obtidos no biogás da amostra 9 através de cromatografia gasosa

Conforme pesquisas de Nogueira (1986) e Neto (2006), uma concentração de $\mathrm{CH}_{4}$ acima de $55 \%$ já torna viável o aproveitamento do biogás para fins energéticos. Por meio dos resultados de cromatografia gasosa verifica-se a alta concentração de $\mathrm{CH}_{4}$ gerada, acima de $70 \%$ para a maioria dos biodigestores, provando-se a qualidade energética do biogás proveniente da biomassa estudada, o que torna interessante o aproveitamento desta fonte de energia a partir destes rejeitos.

No entanto, devido à presença de outros gases, este biogás deve passar por tratamento prévio antes de ser convertido em energia elétrica, o que pode ser realizado em uma estação de tratamento de biogás, como apresentado na figura 3, conforme estudos de Beduschi et al. (1985) citado por Lucas e Silva et al ( 1991 ). 


\subsection{SÓLIDOS TOTAIS}

Os resultados dos ensaios para identificar o percentual de sólidos totais nos resíduos podem ser visualizados na tabela 8 .

Tabela 8- Percentual de sólidos totais

\begin{tabular}{|c|c|c|c|c|c|c|c|c|}
\hline \multicolumn{9}{|c|}{ Peso do Residuo Fresco em Gramas ( $g$ ) } \\
\hline Amostra 01 & Amostra 02 & Amostra 03 & Amostra 04 & Amostra 05 & Amostra 06 & AmostraO & Amostra 08 & Amostra 09 \\
\hline $4.6735 \mathrm{~g}$ & $6,570 \mathrm{~g}$ & $8.5955 \mathrm{~g}$ & $9.1576 \mathrm{~g}$ & $11.8208 \mathrm{~g}$ & $8.4506 \mathrm{~g}$ & $4.8938 \mathrm{~g}$ & $6.4444 \mathrm{~g}$ & $7.5792 \mathrm{~g}$ \\
\hline \multicolumn{9}{|c|}{ Peso do Residuo Queimado a $900^{\circ} \mathrm{C}$ em Gramas ( $\mathrm{g}$ ) } \\
\hline Amostra 01 & Amostra 02 & Amostra 03 & Amostra 04 & Amostra 05 & Amostra 06 & Amostra0 & Amostra 08 & Amostra 09 \\
\hline $0,254 \mathrm{~g}$ & $0,1068 \mathrm{~g}$ & $0,2479 \mathrm{~g}$ & $0,1641 \mathrm{~g}$ & $0,3541 \mathrm{~g}$ & $0,2496 \mathrm{~g}$ & $0,2413 \mathrm{~g}$ & $0,2009 \mathrm{~g}$ & $0,1573 \mathrm{~g}$ \\
\hline \multicolumn{9}{|c|}{ Resultado de Perda ao Fogo a $900^{\circ} \mathrm{C}$ em \% } \\
\hline Amostra 01 & Amostra 02 & Amostra 03 & Amostra 04 & Amostra 05 & Amostra 06 & Amostra 0 & Amostra 08 & Amostra 09 \\
\hline 94,6 & 98,4 & 97,1 & 98,2 & 97,0 & 97,0 & 95,1 & 96,9 & 97,9 \\
\hline
\end{tabular}

Diante dos resultados demonstrados na tabela acima, obteve-se uma média de perda ao fogo em torno de $97 \%$, logo, observa-se que o resíduo de gado leiteiro é basicamente composto de noventa e sete por cento de matéria orgânica de orígem vegetal e umidade. O restante, obtido após a calcinação, são os minerais presentes na alimentação do gado oriunda da pastagem, ração e suplementos minerais para aumentar a lactação.

\subsection{Análises por Espectrometria de Fluorescência de Raios-X}

Os resultados analíticos por Espectrometria de Fluorescência de Raios-X (WDXRF), obtidos para os resíduos queimados a $900^{\circ} \mathrm{C}$, das amostras das 
nove fazendas pesquisadas neste trabalho são apresentados nas tabelas de 9 a 17.

Tabela 9- Espectrometria de Fluorescência de Raios-X da amostra 1

\begin{tabular}{|c|c|c|c|}
\hline Elem./Comp. & $\%$ & Elem./Comp. & $\mu_{\mathrm{g} \mathrm{g}}{ }^{-1}$ \\
\hline $\mathrm{PF}$ & $94,6 \pm 0,5$ & $\mathrm{P}$ & $1490 \pm 30$ \\
\hline $\mathrm{Si}$ & $2,10 \pm 0,05$ & $\mathrm{Fe}$ & $1479 \pm 30$ \\
\hline $\mathrm{Al}$ & $0,71 \pm 0,01$ & $\mathrm{~S}$ & $1014 \pm 20$ \\
\hline $\mathrm{Cl}$ & $0,60 \pm 0,01$ & $\mathrm{Na}$ & $428 \pm 9$ \\
\hline $\mathrm{Mg}$ & $0,60 \pm 0,01$ & $\mathrm{Ti}$ & $218 \pm 4$ \\
\hline $\mathrm{K}$ & $0,52 \pm 0,01$ & $\mathrm{Mn}$ & $88 \pm 2$ \\
\hline $\mathrm{Ca}$ & $0,38 \pm 0,01$ & $\mathrm{Zn}$ & $27 \pm 1$ \\
\hline & & $\mathrm{Cu}$ & $14 \pm 1$ \\
\hline & & $\mathrm{Ni}$ & $12 \pm 1$ \\
\hline & & $\mathrm{Rb}$ & $7 \pm 1$ \\
\hline & & $\mathrm{Sr}$ & $3 \pm 1$ \\
\hline & & $\mathrm{Zr}$ & $1 \pm 1$ \\
\hline & & $\mathrm{Ce}$ & $<1$ \\
\hline
\end{tabular}

$\mathrm{PF}=$ Perda ao fogo

Tabela 10- Espectrometria de Fluorescência de Raios-X da amostra 2

\begin{tabular}{|c|c|c|c|}
\hline Elem./Comp. & $\%$ & Elem./Comp. & $\mu \mathrm{g} \mathrm{g}^{-1}$ \\
\hline $\mathrm{PF}$ & $98,4 \pm 0,5$ & $\mathrm{P}$ & $2444 \pm 49$ \\
\hline $\mathrm{Si}$ & $0,19 \pm 0,01$ & $\mathrm{Fe}$ & $506 \pm 10$ \\
\hline $\mathrm{Al}$ & $0,17 \pm 0,01$ & $\mathrm{~S}$ & $486 \pm 10$ \\
\hline $\mathrm{Cl}$ & $0,12 \pm 0,01$ & $\mathrm{Na}$ & $223 \pm 4$ \\
\hline $\mathrm{Mg}$ & $0,14 \pm 0,01$ & $\mathrm{Ti}$ & $37 \pm 1$ \\
\hline $\mathrm{K}$ & $0,27 \pm 0,01$ & $\mathrm{Mn}$ & $23 \pm 1$ \\
\hline $\mathrm{Ca}$ & $0,33 \pm 0,01$ & $\mathrm{Zn}$ & $18 \pm 1$ \\
\hline & & $\mathrm{Cu}$ & $6 \pm 1$ \\
\hline & & $\mathrm{Ni}$ & $<1$ \\
\hline & & $\mathrm{Rb}$ & $1 \pm 1$ \\
\hline & & $\mathrm{Sr}$ & $5 \pm 1$ \\
\hline & & $\mathrm{Zr}$ & $<1$ \\
\hline & & $\mathrm{Ce}$ & $<1$ \\
\hline
\end{tabular}

$\mathrm{PF}=$ Perda ao fogo 
Tabela 11- Espectrometria de Fluorescência de Raios-X da amostra 3

\begin{tabular}{|c|c|c|c|}
\hline Elem./Comp. & $\%$ & Elem./Comp. & $\mu_{\text {g g }}{ }^{-1}$ \\
\hline $\mathrm{PF}$ & $97,1 \pm 0,5$ & $\mathrm{P}$ & $2257 \pm 45$ \\
\hline $\mathrm{Si}$ & $0,57 \pm 0,01$ & $\mathrm{Fe}$ & $633 \pm 13$ \\
\hline $\mathrm{Al}$ & $0,16 \pm 0,01$ & $\mathrm{~S}$ & $929 \pm 19$ \\
\hline $\mathrm{Cl}$ & $0,24 \pm 0,01$ & $\mathrm{Na}$ & $238 \pm 5$ \\
\hline $\mathrm{Mg}$ & $0,36 \pm 0,01$ & $\mathrm{Ti}$ & $53 \pm 1$ \\
\hline $\mathrm{K}$ & $0,45 \pm 0,01$ & $\mathrm{Mn}$ & $41 \pm 1$ \\
\hline $\mathrm{Ca}$ & $0,69 \pm 0,01$ & $\mathrm{Zn}$ & $36 \pm 1$ \\
\hline & & $\mathrm{Cu}$ & $18 \pm 1$ \\
\hline & & $\mathrm{Ni}$ & $16 \pm 1$ \\
\hline & & $\mathrm{Rb}$ & $3 \pm 1$ \\
\hline & & $\mathrm{Sr}$ & $7 \pm 1$ \\
\hline & & $\mathrm{Zr}$ & $<1$ \\
\hline & & $\mathrm{Ce}$ & $123 \pm 2$ \\
\hline
\end{tabular}

$\mathrm{PF}=$ Perda ao fogo

Tabela 12- Espectrometria de Fluorescência de Raios-X da amostra 4

\begin{tabular}{|c|c|c|c|}
\hline Elem./Comp. & $\%$ & Elem./Comp. & $\mu \mathrm{g} \mathrm{g}^{-1}$ \\
\hline $\mathrm{PF}$ & $98,2 \pm 0,5$ & $\mathrm{P}$ & $1545 \pm 31$ \\
\hline $\mathrm{Si}$ & $0,42 \pm 0,01$ & $\mathrm{Fe}$ & $170 \pm 3$ \\
\hline $\mathrm{Al}$ & $0,04 \pm 0,01$ & $\mathrm{~S}$ & $620 \pm 12$ \\
\hline $\mathrm{Cl}$ & $0,21 \pm 0,01$ & $\mathrm{Na}$ & $208 \pm 4$ \\
\hline $\mathrm{Mg}$ & $0,17 \pm 0,01$ & $\mathrm{Ti}$ & $<1$ \\
\hline $\mathrm{K}$ & $0,43 \pm 0,01$ & $\mathrm{Mn}$ & $33 \pm 1$ \\
\hline $\mathrm{Ca}$ & $0,26 \pm 0,01$ & $\mathrm{Zn}$ & $23 \pm 1$ \\
\hline & & $\mathrm{Cu}$ & $10 \pm 1$ \\
\hline & & $\mathrm{Ni}$ & $3 \pm 1$ \\
\hline & & $\mathrm{Rb}$ & $2 \pm 1$ \\
\hline & & $\mathrm{Sr}$ & $3 \pm 1$ \\
\hline & & $\mathrm{Zr}$ & $<1$ \\
\hline & & $\mathrm{Ce}$ & $57 \pm 1$ \\
\hline
\end{tabular}

$\mathrm{PF}=$ Perda ao fogo 
Tabela 13- Espectrometria de Fluorescência de Raios-X da amostra 5

\begin{tabular}{|c|c|c|c|}
\hline Elem./Comp. & $\%$ & Elem./Comp. & $\mu \mathrm{g} \mathrm{g}^{-1}$ \\
\hline $\mathrm{PF}$ & $97,0 \pm 0,5$ & $\mathrm{P}$ & $5444 \pm 109$ \\
\hline $\mathrm{Si}$ & $0,26 \pm 0,01$ & $\mathrm{Fe}$ & $642 \pm 13$ \\
\hline $\mathrm{Al}$ & $0,09 \pm 0,01$ & $\mathrm{~S}$ & $1118 \pm 22$ \\
\hline $\mathrm{Cl}$ & $0,24 \pm 0,01$ & $\mathrm{Na}$ & $953 \pm 19$ \\
\hline $\mathrm{Mg}$ & $0,24 \pm 0,01$ & $\mathrm{Ti}$ & $30 \pm 1$ \\
\hline $\mathrm{K}$ & $0,36 \pm 0,01$ & $\mathrm{Mn}$ & $135 \pm 3$ \\
\hline $\mathrm{Ca}$ & $0,98 \pm 0,01$ & $\mathrm{Zn}$ & $33 \pm 1$ \\
\hline & & $\mathrm{Cu}$ & $12 \pm 1$ \\
\hline & & $\mathrm{Ni}$ & $3 \pm 1$ \\
\hline & & $\mathrm{Rb}$ & $2 \pm 1$ \\
\hline & & $\mathrm{Sr}$ & $15 \pm 1$ \\
\hline & & $\mathrm{Zr}$ & $<1$ \\
\hline & & $\mathrm{Ce}$ & $<1$ \\
\hline
\end{tabular}

$\mathrm{PF}=$ Perda ao fogo

Tabela 14- Espectrometria de Fluorescência de Raios-X da amostra 6

\begin{tabular}{|c|c|c|c|}
\hline Elem./Comp. & $\%$ & Elem./Comp. & $\mu \mathrm{g} \mathrm{g}^{-1}$ \\
\hline $\mathrm{PF}$ & $97,0 \pm 0,5$ & $\mathrm{P}$ & $3574 \pm 71$ \\
\hline $\mathrm{Si}$ & $0,32 \pm 0,01$ & $\mathrm{Fe}$ & $275 \pm 6$ \\
\hline $\mathrm{Al}$ & $0,07 \pm 0,01$ & $\mathrm{~S}$ & $627 \pm 13$ \\
\hline $\mathrm{Cl}$ & $0,44 \pm 0,01$ & $\mathrm{Na}$ & $832 \pm 17$ \\
\hline $\mathrm{Mg}$ & $0,36 \pm 0,01$ & $\mathrm{Ti}$ & $<1$ \\
\hline $\mathrm{K}$ & $0,65 \pm 0,01$ & $\mathrm{Mn}$ & $65 \pm 1$ \\
\hline $\mathrm{Ca}$ & $0,61 \pm 0,01$ & $\mathrm{Zn}$ & $16 \pm 1$ \\
\hline & & $\mathrm{Cu}$ & $6 \pm 1$ \\
\hline & & $\mathrm{Ni}$ & $<1$ \\
\hline & & $\mathrm{Rb}$ & $40 \pm 1$ \\
\hline & & $\mathrm{Sr}$ & $60 \pm 1$ \\
\hline & & $\mathrm{Zr}$ & $<1$ \\
\hline & & $\mathrm{Ce}$ & $<1$ \\
\hline
\end{tabular}

$\mathrm{PF}=$ Perda ao fogo 
Tabela 15- Espectrometria de Fluorescência de Raios-X da amostra 7

\begin{tabular}{|c|c|c|c|}
\hline Elem./Comp. & $\%$ & Elem./Comp. & $\mu \mathrm{g} \mathrm{g}^{-1}$ \\
\hline $\mathrm{PF}$ & $95,1 \pm 0,5$ & $\mathrm{P}$ & $3678 \pm 74$ \\
\hline $\mathrm{Si}$ & $1,41 \pm 0,05$ & $\mathrm{Fe}$ & $840 \pm 17$ \\
\hline $\mathrm{Al}$ & $0,33 \pm 0,01$ & $\mathrm{~S}$ & $1539 \pm 31$ \\
\hline $\mathrm{Cl}$ & $0,29 \pm 0,01$ & $\mathrm{Na}$ & $165 \pm 3$ \\
\hline $\mathrm{Mg}$ & $0,47 \pm 0,01$ & $\mathrm{Ti}$ & $86 \pm 2$ \\
\hline $\mathrm{K}$ & $0,45 \pm 0,01$ & $\mathrm{Mn}$ & $75 \pm 2$ \\
\hline $\mathrm{Ca}$ & $1,30 \pm 0,05$ & $\mathrm{Zn}$ & $61 \pm 1$ \\
\hline & & $\mathrm{Cu}$ & $29 \pm 1$ \\
\hline & & $\mathrm{Ni}$ & $9 \pm 1$ \\
\hline & & $\mathrm{Rb}$ & $4 \pm 1$ \\
\hline & & $\mathrm{Sr}$ & $7 \pm 1$ \\
\hline & & $\mathrm{Zr}$ & $2 \pm 1$ \\
\hline & & $\mathrm{Ce}$ & $<1$ \\
\hline
\end{tabular}

$\mathrm{PF}=$ Perda ao fogo

Tabela 16- Espectrometria de Fluorescência de Raios-X da amostra 8

\begin{tabular}{|c|c|c|c|}
\hline Elem./Comp. & $\%$ & Elem./Comp. & $\mu \mathrm{g} \mathrm{g}^{-1}$ \\
\hline $\mathrm{PF}$ & $96,9 \pm 0,5$ & $\mathrm{P}$ & $2306 \pm 46$ \\
\hline $\mathrm{Si}$ & $1,31 \pm 0,05$ & $\mathrm{Fe}$ & $952 \pm 19$ \\
\hline $\mathrm{Al}$ & $0,27 \pm 0,01$ & $\mathrm{~S}$ & $809 \pm 16$ \\
\hline $\mathrm{Cl}$ & $0,10 \pm 0,01$ & $\mathrm{Na}$ & $130 \pm 3$ \\
\hline $\mathrm{Mg}$ & $0,22 \pm 0,01$ & $\mathrm{Ti}$ & $132 \pm 3$ \\
\hline $\mathrm{K}$ & $0,18 \pm 0,01$ & $\mathrm{Mn}$ & $54 \pm 1$ \\
\hline $\mathrm{Ca}$ & $0,59 \pm 0,01$ & $\mathrm{Zn}$ & $30 \pm 1$ \\
\hline & & $\mathrm{Cu}$ & $13 \pm 1$ \\
\hline & & $\mathrm{Ni}$ & $5 \pm 1$ \\
\hline & & $\mathrm{Rb}$ & $2 \pm 1$ \\
\hline & & $\mathrm{Sr}$ & $6 \pm 1$ \\
\hline & & $\mathrm{Zr}$ & $1 \pm 1$ \\
\hline & & $\mathrm{Ce}$ & $<1$ \\
\hline
\end{tabular}

$\mathrm{PF}=$ Perda ao fogo 
Tabela 17- Espectrometria de Fluorescência de Raios-X da amostra 9

\begin{tabular}{|c|c|c|c|}
\hline Elem./Comp. & $\%$ & Elem./Comp. & $\mu \mathrm{g} \mathrm{g}^{-1}$ \\
\hline $\mathrm{PF}$ & $97,9 \pm 0,5$ & $\mathrm{P}$ & $583 \pm 12$ \\
\hline $\mathrm{Si}$ & $1,22 \pm 0,05$ & $\mathrm{Fe}$ & $346 \pm 7$ \\
\hline $\mathrm{Al}$ & $0,12 \pm 0,01$ & $\mathrm{~S}$ & $408 \pm 8$ \\
\hline $\mathrm{Cl}$ & $0,15 \pm 0,01$ & $\mathrm{Na}$ & $222 \pm 4$ \\
\hline $\mathrm{Mg}$ & $0,10 \pm 0,01$ & $\mathrm{Ti}$ & $47 \pm 1$ \\
\hline $\mathrm{K}$ & $0,22 \pm 0,01$ & $\mathrm{Mn}$ & $96 \pm 2$ \\
\hline $\mathrm{Ca}$ & $0,12 \pm 0,01$ & $\mathrm{Zn}$ & $8 \pm 1$ \\
\hline & & $\mathrm{Cu}$ & $4 \pm 1$ \\
\hline & & $\mathrm{Ni}$ & $4 \pm 1$ \\
\hline & & $\mathrm{Rb}$ & $2 \pm 1$ \\
\hline & & $\mathrm{Sr}$ & $1 \pm 1$ \\
\hline & & $\mathrm{Zr}$ & $<1$ \\
\hline & & $\mathrm{Ce}$ & $<1$ \\
\hline
\end{tabular}

$\mathrm{PF}=$ Perda ao fogo

Com os dados das tabelas 9 a 17, fez-se uma média das concentrações dos elementos encontrados nos resíduos das nove fazendas pesquisadas conforme apresentado na tabela 18. 
Tabela 18 - Média dos Resultados Analíticos por Espectrometria de Fluorescência de Raios-X (WDXRF) dos Resíduos do gado leiteiro

\begin{tabular}{|c|c|c|c|}
\hline Elem/Comp & Resultado em \% & Elem/Comp & Resultado em $\boldsymbol{\mu g} \mathbf{~ g - 1}$ \\
\hline $\mathbf{S i}$ & 0,87 & $\mathbf{T i}$ & 86,14 \\
\hline $\mathbf{A l}$ & 0,218 & $\mathbf{M n}$ & 68,0 \\
\hline $\mathbf{C l}$ & 0,265 & $\mathbf{Z n}$ & 28,0 \\
\hline $\mathbf{M g}$ & 0,30 & $\mathbf{C u}$ & 12,5 \\
\hline $\mathbf{K}$ & 0,40 & $\mathbf{N i}$ & 7,5 \\
\hline $\mathbf{C a}$ & 0,60 & $\mathbf{R b}$ & 7,0 \\
\hline- & - & $\mathbf{S r}$ & 12,0 \\
\hline- & - & $\mathbf{Z r}$ & 1,3 \\
\hline- & - & $\mathbf{C e}$ & 90,0 \\
\hline- & - & $\mathbf{P}$ & 2.592 \\
\hline- & - & $\mathbf{F e}$ & 650,00 \\
\hline- & - & $\mathbf{S}$ & 839,00 \\
\hline- & - & $\mathbf{N a}$ & 378,00 \\
\hline
\end{tabular}

Nota-se pela tabela 18 que há uma concentração média relativamente alta para os elementos $\mathrm{P}, \mathrm{Fe}, \mathrm{S}, \mathrm{Ti}, \mathrm{Mn}, \mathrm{Zn}$ e Na. Para os demais, os traços detectados podem ter origem na composição química do solo da região.

O elemento $P$ é um dos principais causadores de eutrofização de corpos aquáticos. Diante disso, é imprescindível a devida disposição e o devido tratamento destes resíduos.

A presença e a concentração de metais como $\mathrm{Zn}$, $\mathrm{Fe}$ e $\mathrm{Mn}$ são regulamentadas pela resolução CONAMA № 357, de 17 de março de 2005, a qual estabelece os limites máximos desses e outros em efluentes de qualquer fonte poluidora. Para o $\mathrm{Zn}$ total o limite é $5,0 \mathrm{mg} / \mathrm{L}$, para o Fe é de $15,0 \mathrm{mg} / \mathrm{L}$, e para o $\mathrm{Mn}$ dissolvido o limite é $1,0 \mathrm{mg} / \mathrm{L}$. Observa-se que para $\mathrm{Zn}$ o valor não excedeu o limite estabelecido pela resolução. No entanto, o mesmo não aconteceu com o $\mathrm{Fe}$ e o $\mathrm{Mn}$, pois em todas as amostras os valores excederam para estes elementos. É possível que tais concentrações estejam relacionadas 
com a composição geoquímica do solo na região, que está relativamente próxima ao Quadrilátero ferrífero e à região metalúrgica de Minas Gerais.

O Mn é um metal de cor cinzenta, amplamente utilizado na indústria metalúrgica e agroquímica, sendo amplamente encontrado na natureza. Conforme estudos de Macedo (2001), a toxicidade sistêmica por Mn é mais comum na exposição crônica por inalação e ingestão. Os maiores efeitos da exposição prolongada ao $\mathrm{Mn}$ são sobre sistema nervoso central, após períodos variáveis de seis meses a três anos de exposição a elevadas concentrações.

$\mathrm{Na}$ maioria das vezes o $\mathrm{Fe}$ e $\mathrm{Mn}$ estão associados, conferindo à água um sabor amargo, adstringente, coloração amarelada e turva. $\mathrm{O}$ Mn pode apresentar sabor desagradável e causa incrustações em tecidos e obstruções em equipamentos, quando em concentrações acima de 0,15 mg/L, como demonstram estudos de Rabello (2006).

Segundo Silveira (2004), metais pesados inferem toxicidade ao ecossistema quando são lançados aos recursos hídricos, sendo acumulados nas bases dos níveis tróficos e conseqüentemente se estendendo por toda a teia alimentar destes ecossistemas. Entre as classes de invertebrados, os peixes representam o último nível trófico de transferência dos metais pesados. Como conseqüência, a morte destes é inevitável, provocada principalmente pela precipitação das proteínas responsável pela hematose em seu sistema respiratório, fazendo com que morram por asfixia.

Juntos, os elementos $\mathrm{S}$ e $\mathrm{Na}$ podem causar maus odores, toxicidade e aumentar a acidez do solo e da água e, conseqüentemente, causarem alterações geoquímicas na bacia hidrográfica local. $\mathrm{O} S$ quando associado a outros compostos químicos naturais presentes no solo, poderá formar íons sulfato $\left(\mathrm{SO}_{4}{ }^{2-}\right)$, produzindo efeito laxativo, segundo Silveira (2004). Ademais o $S$ está associado à formação de gás sulfídrico $\left(\mathrm{H}_{2} \mathrm{~S}\right)$ conferindo maus odores aos resíduos e acidez ao solo e à água, podendo causar alterações geoquímicas na hidrografia local. 
O tratamento destes resíduos seria, assim, de suma importância, pois como pode ser observado na figura 17, a maioria das fazendas estão localizadas próximas aos corpos aquáticos superficiais da região, o que pode acarretar uma série de consequências ambientais negativas no Meio Ambiente local e regional.

Conforme Nogueira (1986), para cada $\mathrm{kg}$ de esterco de gado bovino podem ser produzidos $0,04 \mathrm{~m}^{3}$ de biogás, assim sendo, as fazendas estudadas poderão obter quantidades expressivas de biogás conforme calculado e demonstrado na figura 30 . 


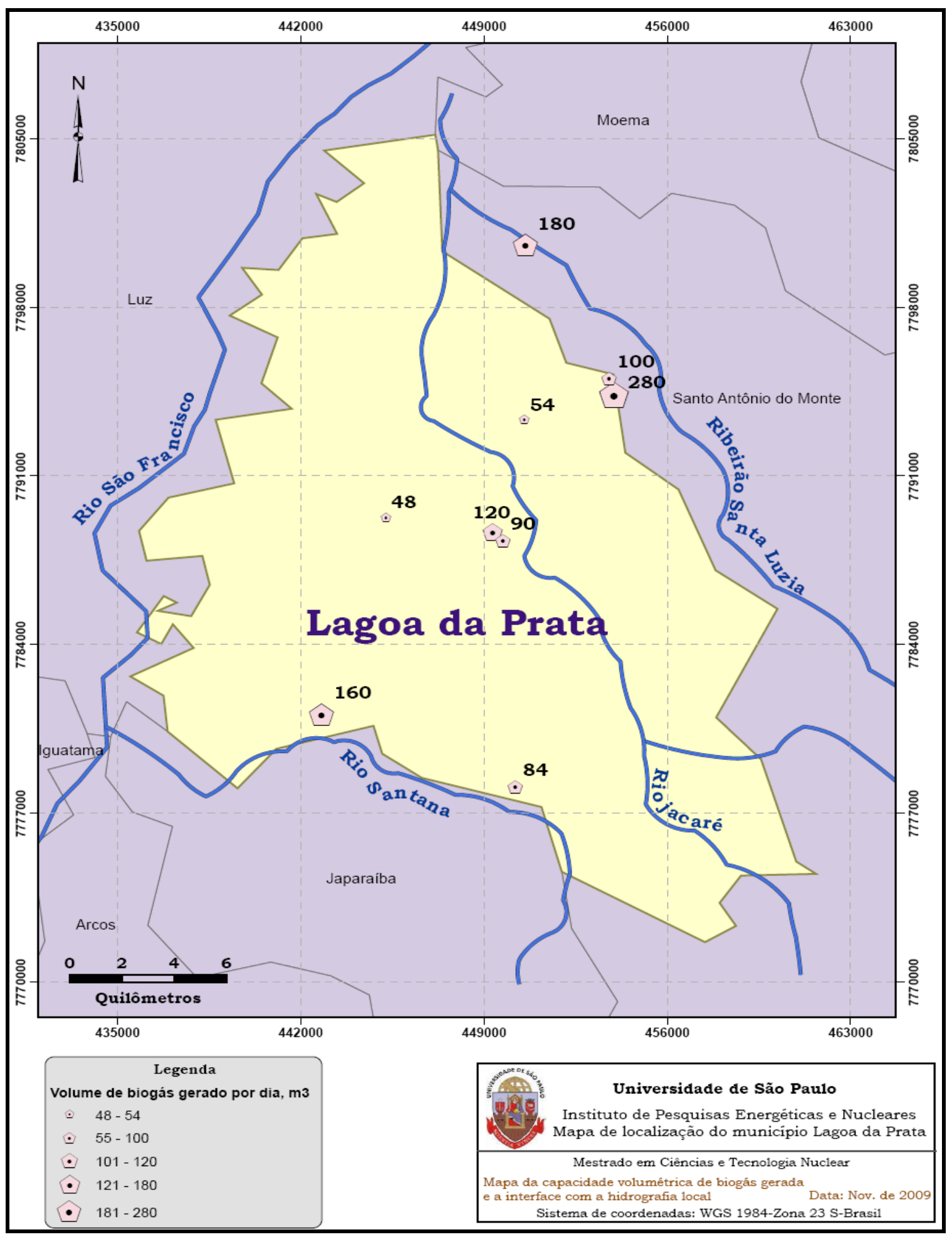

Figura 30: Mapa do potencial de geração de biogás nas fazendas estudadas

Fonte: Elaboração própria 
O biogás é um dos produtos obtidos com a biodigestão dos resíduos que pode ser utilizado após um simples tratamento de purificação conforme é detalhado na figura 3 para retirar os traços de $\mathrm{H}_{2} \mathrm{~S}$ e $\mathrm{CO}_{2}$, sobrando o $\left(\mathrm{CH}_{4}\right)$ e ser utilizado para gerar energia elétrica através de um gerador ou mesmo por queima direta, para aquecimento de água e dos currais em dias frios. Assim, as fazendas poderão ter seus custos diminuídos ou mesmo se tornarem autosuficientes em energia.

Neste sentido, apresenta-se a tabela 19 onde consta uma relação de equipamentos energointensivos comuns à pecuária leiteira.

\section{Tabela 19- Equipamentos Energointensivos}

\begin{tabular}{|c|c|}
\hline & $\begin{array}{l}\text { Equipamentos Energointensivos nas } \\
\text { Fazendas }\end{array}$ \\
\hline & Refrigeradores \\
\hline & Compressores \\
\hline & Ordenhadeiras \\
\hline & Aquecedores de água \\
\hline & Forrageiras \\
\hline & Misturadores \\
\hline & Bombas d'água \\
\hline
\end{tabular}

Os equipamentos listados acima são de uso constante e intensivo nas fazendas, gerando um alto consumo de energia elétrica e térmica. $O$ consumo mensal médio de energia elétrica ocasionado pelo uso destes equipamentos e iluminação, dentre outros, pode ser observado na figura 31. Estes dados foram retirados do questionário respondido pelos responsáveis das fazendas 


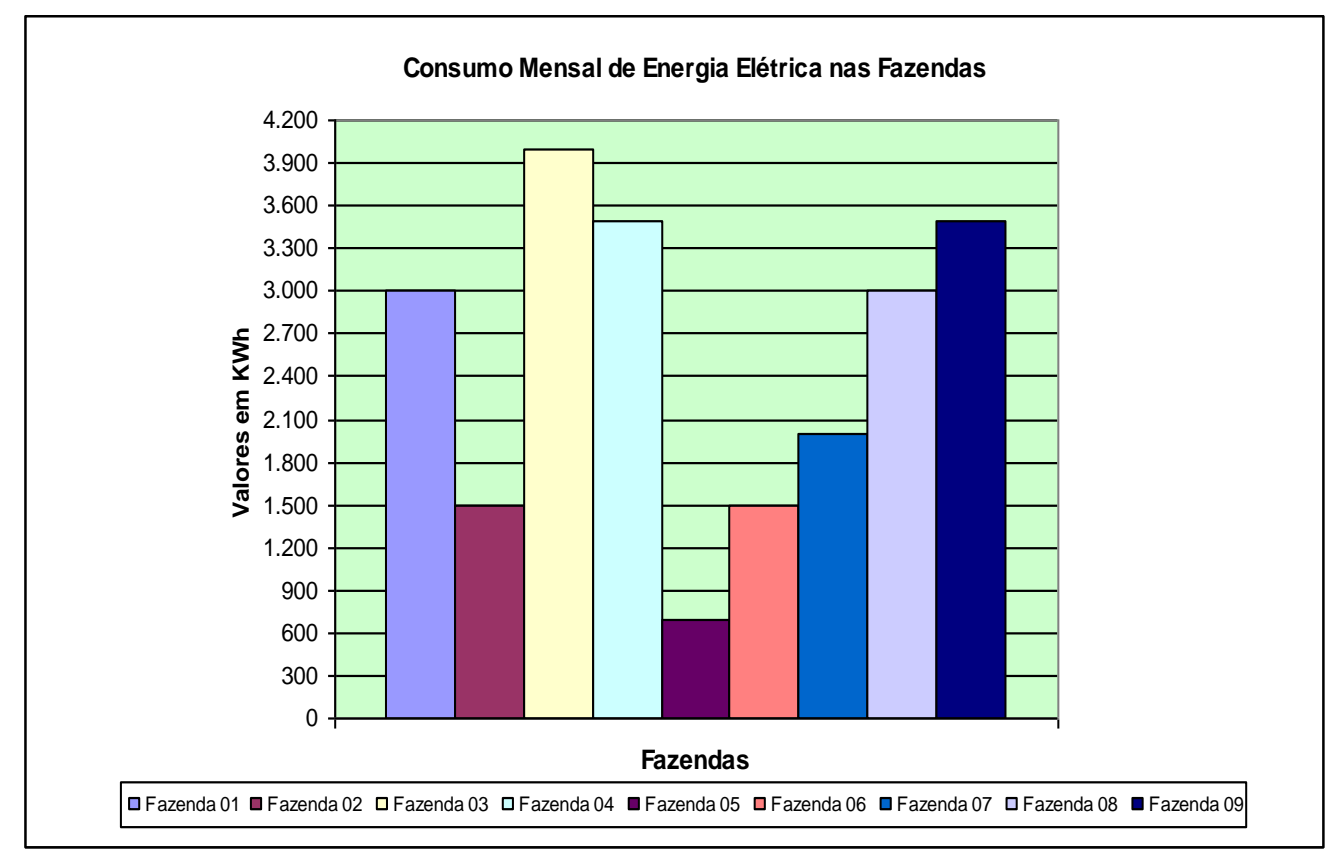

Figura 31 - Gráfico do consumo mensal médio de energia elétrica nas fazendas visitadas

No gráfico pode-se observar como é alta a demanda de energia elétrica em empreendimentos agropecuários, assim onerando o negócio com o consumo de energia elétrica.

Conforme pesquisas de Nogueira (1986), $1 \mathrm{~m}^{3}$ de biogás pode gerar 1,2 KWh de energia elétrica, assim estimou-se o potencial de geração de bioeletricidade nas fazendas pesquisadas. Os resultados estão apresentados na figura 32. Diante dos resultados, é possível se fazer uma leitura do potencial energético a partir da utilização da biomassa residual de gado leiteiro. 


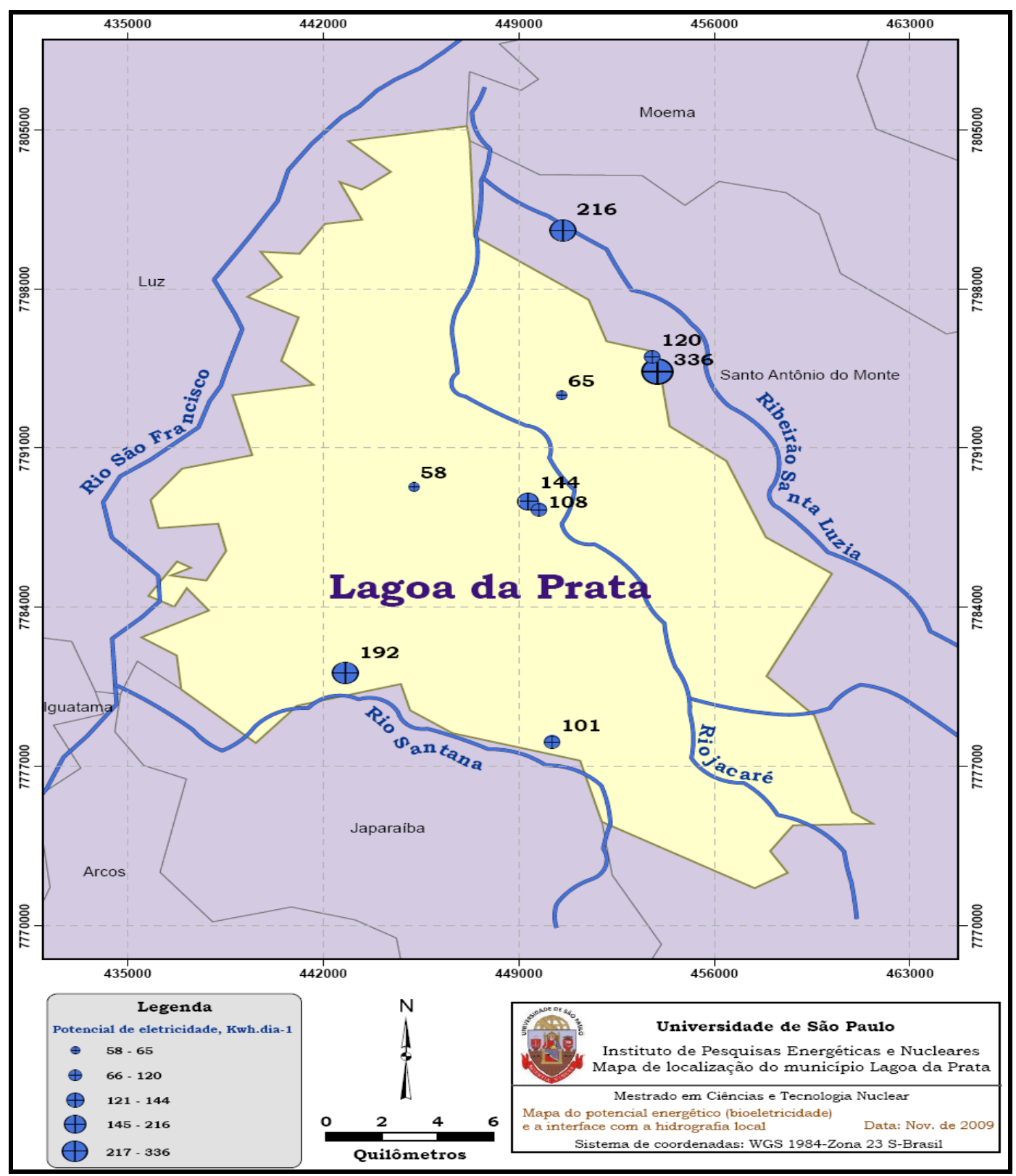

Figura 32: Mapa do potencial de geração de bioeletricidade a partir do uso dos resíduos de gado leiteiro

\section{Fonte: Elaboração própria}

Neste sentido, cabe ressaltar que também são interessantes os dados ambientais demonstrados nestas pesquisas. Dados estes que sinalizam a 
realização de pesquisas mais detalhadas dos impactos ambientais da pecuária leiteira na região de Lagoa da Prata. 


\section{CONCLUSÃO}

Pelos resultados apresentados neste trabalho nota-se o quanto é expressivo o volume de resíduos gerados diariamente pelos rebanhos nas fazendas estudadas e que são dispostos no solo sem qualquer tratamento prévio.

Os resultados analíticos obtidos em laboratório apoiaram as hipóteses evidenciadas em campo e servirão de apoio para projetos futuros sobre o tema naquela região.

Observou-se que o percentual médio de perda ao fogo do resíduo foi de $97 \%$ nos ensaios de resíduos sólidos totais, isso demonstrou o quanto o resíduo possui alta quantidade de biomassa volátil e alto teor de umidade.

Nas medidas de $\mathrm{pH}$, as leituras obtidas se mantiveram na média entre 5 e 6. Um pH na faixa entre 6 e 8 seria a faixa ideal para ocorrer a biodigestão com boa produção de biogás, conforme pesquisas de Nogueira ( 1986), no entanto o ajuste de $\mathrm{pH}$ em biodigestores implantados em campo é algo viável de se resolver com acréscimo de matéria orgânica morta como restos de culturas tais como palhas e sobras de lavouras de milho, cana entre outras ou mesmo acréscimo de cal. Ademais, cumpre ressaltar que autores como Nogueira, Neto e Lucas Junior descrevem em suas pesquisas que se deve implantar agitadores ou sopradores com ar comprimido para melhorar a dinamização e uniformizar os resíduos dentro dos biodigestores e assim equilibrar o $\mathrm{pH}$ no sistema.

Os resultados obtidos na análise de espectrometria de fluorescência de raios-X demonstram a necessidade de se investigar mais detalhadamente os impactos ambientais da deposição dos resíduos sobre o solo e dos corpos aquáticos da região. Evidenciou-se a presença de concentrações relativamente altas de alguns elementos tais como Ti, Mn, Zn, Ce, Fe, P, S e Na. Neste 
sentido, cabe ressaltar a importância de se fazerem diversas análises para investigar e comprovar se há contaminação na região hidrográfica de Lagoa da Prata por tais elementos químicos.

Através dos resultados de cromatografia gasosa foi possível se ter uma leitura da boa qualidade energética do biogás, uma vez que a concentração média de $\mathrm{CH}_{4}$ esteve em torno de $70 \%$, pois pesquisas de Nogueira (1986) demonstraram que concentrações acima de $55 \%$ já são viáveis para aproveitamento energético. Assim, a concentração de $\mathrm{CH}_{4}$ dos diferentes biodigestores se mostrou interessante para o aproveitamento desta fonte de energia.

O aproveitamento dos dejetos para geração de energia pode ser considerado apenas um dos ganhos que podem ocorrer com a biodigestão, pois haverá maior independência energética. Outro ganho que se deve levar em conta é o aproveitamento dos dejetos após a biodigestão, pois o efluente gerado nada mais é que um excelente biofertilizante.

As pesquisas de campo demonstraram o quanto são relevantes os aspectos ambientais que envolvem a pecuária leiteira na região de Lagoa da Prata. Neste sentido, atenção especial deverá ser dada a estas questões, uma vez que a região está inserida na bacia hidrográfica do Alto São Francisco. Políticas públicas voltadas ao manejo sustentável da pecuária leiteira naquela região trarão ganhos ambientais que vão ao encontro com o projeto do Governo Federal de revitalização do Rio São Francisco

Cumpre destacar que a geração de energia elétrica a partir da utilização da biomassa residual de gado leiteiro é uma forma de geração de energia distribuída no campo e pode contribuir para a auto-suficiência das fazendas com energia elétrica obtida através de uma fonte limpa e renovável. Isto vai ao encontro do Programa de Incentivo às Fontes Alternativas de Energia Elétrica (Proinfa), conforme descrito no Decreto no 5.025, de 2004, que foi instituído com o objetivo de aumentar a participação de fontes de energias renováveis na 
matriz elétrica brasileira.

Ademais, esta pesquisa se alinha com os propósitos do Plano Nacional de Agroenergia do Ministério da Agricultura, Pecuária e Abastecimento que tem, entre os diversos objetivos, os seguintes:

- Propiciar condições para o aumento da participação de fontes de agroenergia na composição da matriz energética;

- Gerar condições para permitir a interiorização e a regionalização do desenvolvimento, fundadas na expansão da agricultura de energia e na agregação de valor à cadeia produtiva;

- Contribuir para reduzir as emissões de gases de efeito estufa.

Esse último item pode ser corroborado, pois a geração de energia elétrica e utilização do biofertilizante poderão propiciar, ainda, lucros com a obtenção de créditos de emissões reduzidas (CERs), estabelecidos no mecanismo de desenvolvimento limpo conforme preconiza o MCT (2001).

O biofertilizante que se pode obter com a implantação de biodigestores é um produto rico em micronutrientes vitais para a agricultura. Assim, este produto incorpora valor ao resíduo como insumo aproveitável de maneira útil nas fazendas através da adubação em plantações de capim, milho e outras culturas comuns na pecuária leiteira ou mesmo comercializar o excedente para terceiros através de consórcios ou parcerias com agricultores da região, uma vez que em diversos municípios vizinhos há imensas plantações de café, cana, feijão e outras culturas.

Os biodigestores são amplamente difundidos no mercado, com diversas empresas no Sul e Sudeste do Brasil, de tecnologia simples e com custos acessíveis. Ressalta-se que há diversas linhas de financiamentos em instituições financeiras com juros baixos para empreendimentos que visem à sustentabilidade ambiental. Portanto, torna viável a implantação de um projeto de aproveitamento de dejetos de gado leiteiro para fins energéticos do ponto de 
vista econômico.

Pelo exposto, o aproveitamento desta biomassa residual, com a instalação de biodigestores nestes empreendimentos, além de prevenir eventuais poluições ao meio ambiente, poderá proporcionar uma autosuficiência energética aos produtores de leite da região de Lagoa da Prata. Diante disso, observa-se que pesquisas nesta área podem alcançar os objetivos das políticas públicas do país, cabendo incentivos concretos de ações locais no interior do Brasil.

Portanto, conclui-se esta pesquisa ressaltando a importância de se desenvolver futuros projetos pilotos na região de Lagoa da Prata com o objetivo de se implantar biodigestores nas fazendas da região. Assim, aproveitar na prática o potencial energético da biomassa residual da pecuária leiteira, uma vez que há disponibilidade de resíduos e é uma vocação regional. Ademais, cabe enfatizar a necessidade de se fazer uma investigação ambiental preliminar na bacia hidrográfica local. 


\section{REFERÊNCIAS BIBLIOGRÁFICAS}

1 Agnew, R. E; Yan, T: Impact of recent research on energy feeding systems for dairy cattle Livestock Production Science, Volume 66, Issue 3, November 2000, Pages 197-215

2 AGUIAR, A. P. A.: Sustentabilidade Técnica, Econômica e Social dos Sistemas de Produção de Leite a Pasto. In: MARTINS, C. E. et al. Sustentabilidade de Sistemas de Sistemas de Produção de Leite a Pasto e Confinamento. Juiz de Fora: Embrapa Gado de Leite, 2001, p. 27-60.

3 ALBERTTO, C; MADALENE, B e DALVAN, J.: Efeito de pisoteio animal no terceiro ano consecutivo, sobre algumas propriedades físicas do solo e produtividade do milho em solo sob plantio direto e convencional. Disponível em www.ufsm.br/ppgcs/congressos/xxvi-congresso brasileiro/ rq 718. pdf. Acesso em 15 se setembro de 2006.

4 AMON ,T; AMON, B; KRYVORUCHKO,V; ZOLLITSCH, W; MAYER, K; GRUBER, L: Biogas production from maize and dairy cattle manureInfluence of biomass composition on the methane yield, Agriculture, Ecosystems and Environment 118 (2007) 173-182

5 Amon, B; Kryvoruchko, V; Amon, T; Zechmeister-Boltenstern, S: Methane, nitrous oxide and ammonia emissions during storage and after application of dairy cattle slurry and influence of slurry treatment Agriculture, Ecosystems \& Environment, Volume 112, Issues 2-3, February 2006, Pages 153-162.

6 ANEEL (2008). Atlas de Energia Elétrica do Brasil, Brasília: Aneel, 3a edição.

7 Beauchemin, K.A; McGinn, S.M; Benchaar C; Holtshausen, L: Crushed sunflower, flax, or canola seeds in lactating dairy cow diets: Effects on methane production, rumen fermentation, and milk production Journal of Dairy Science, Volume 92, Issue 5, May 2009, Pages 2118-2127

8 BENINCASA, M.; ORTOLANI, A. F.; LUCAS JUNIOR, J: Biodigestores convencionais. Faculdade de Ciências Agrárias e Veterinárias. Jaboticabal, 1991. 25p.

9 BLEY J.R,: Capítulo 3 - Agroenergia, 27 p. (Relatório de Cícero Bley Jr. para o PCT FAO-Itaipu - Projeto da biomassa residual - Agroenergia da 
biomassa residual: perspectivas socioeconômicas, ambientais e energéticas). 2008a.

10 CAMPOS, A. T. Manejo de dejetos de bovinos. In: III Encontro nacional de técnicos, pesquisadores e educadores de construções rurais. XXVII CONBEA. Lavras: UFLA. p.233-79, 1998.

11 CASAGRANDE, L.F: Avaliação descritiva de desempenho e sustentabilidade entre uma granja suinícola convencional e outra dotada de biossistema integrado (B.S.I.). Florianópolis: UFSC, Programa de Pósgraduação em Engenharia de Produção, 125 p.(Dissertação de Mestrado), 2003.

12 Chadwick, D.R: Emissions of ammonia, nitrous oxide and methane from cattle manure heaps: effect of compaction and covering Atmospheric Environment, Volume 39, Issue 4, February 2005, Pages 787799

Hill, D.T: Design parameters and operating characteristics of animal waste anaerobic digestion systems. Dairy cattle Agricultural Wastes, Volume 5, Issue 4, April 1983, Pages 219-230

13 CLEMENS, J; TRIMBORN, M; WEILAND P; AMON,B: Mitigation of greenhouse gas emissions by anaerobic digestion of cattle slurry, Agriculture, Ecosystems and Environment 112 (2006) 171-177.

14 COMASTRI, F.J.A: Biogás, independência energética do Pantanal Matogrossense.EMBRAPA. UEPAE de Corumbá. Circular Técnica, 9. Corumbá. 1981.53p.

15 COTTON, W.R; PIELKE, R.A: Human impacts on weather and climate. Cambridge University ress, 1995. 288p.

16 DELGADO, Christopher \& outros (1999). Livestock to 2020 - The Next Food Revolution. 2020 Vision. Washington: International Food Policy Research Institute; Food and Agriculture Organization e International Livestock Research Institute, maio de 1999, 83 p. (Food, Agriculture and the Environment Discussion Paper, \# 28).

16 DEMIRER, G.N; CHEN, S: Anaerobic biogasification of undiluted dairy manure in leaching bed reactors, Waste Management 28 (2008) 112-119.

17 Ellis J.L; Kebreab, E; Odongo N.E; McBride, B.W; Okine E.K; France J: Prediction of Methane Production from Dairy and Beef Cattle. Journal of Dairy Science, Volume 90, Issue 7, July 2007, Pages 3456-3466 
18 EMBRAPA: Centro Nacional de Pesquisa em Aves e Suínos. Manejo de dejetos de suínos. Concórdia, 1998. 31p. (Boletim Informativo de Pesquisa, 11)

19 Erdman, M. D: Mesophilic methane fermentation of low-solids dairy-cattle waste Agricultural Wastes, Volume 13, Issue 2, 1985, Pages 115-129

20 FAGUNDES, M. H. L: Situação atual e perspectivas para o setor. Conjunturas Agropecuárias, Estudos Especiais. Brasília: CONAB, 2003. 32p. Disponível em http://www.conab.gov.br/downloads/cas/especiais/LEITE\%2026\%20AGOS TO.pdf>. Acesso em: 27 Ago. 2003.

21 FUSCO, C: Entrevista com Michael Liebreich, publicada na Revista Exame, edição 0909, de 25.12.07.

22 GALINKIN, M: Agroenergia da biomassa residual: Perspectivas energéticas, socioeconômicas e ambientais. Foz do Iguaçu/ Brasília: Itaipu Binacional, ONU para Agricultura e Alimentação, 2009. 140 p.

23 GARCIA,V.E: Projeto e construção de alojamento para animais. 2ed. Lisboa: Litexa-Portugual, 237p. 1981.

24 Garnsworthy,P.C: The environmental impact of fertility in dairy cows: a modelling approach to predict methane and ammonia emissions Animal Feed Science and Technology, Volume 112, Issues 1-4, 10 February 2004, Pages 211-223

25 Getachew, G.P.H; Robinson, E.J; Depeters, S.J; Taylor, D.D;. Gisi, G.E. Higginbotham, G.E; Riordan, T.J.: Methane production from commercial dairy rations estimated using an in vitro gas technique. Animal Feed Science and Technology, Volumes 123-124, Part 1, 30 September 2005, Pages

391-402

26 GOMES, A. T.; ZOCCAL, R: Caracterização da produção de leite nas principais regiões produtoras do País. In: MARTINS, C. E; ALENCAR, C. A. B.; BRESSAN, M: Sustentabilidade da produção do leite no Leste Mineiro. Juiz de Fora: Embrapa Gado de Leite, 2001, p. 7-17.

27 González, A. E; Suárez, L. G. R: Methane emission factors from cattle manure in Mexico Bioresource Technology, Volume 80, Issue 1, October 2001, Pages 63-71

28 HARDOIM, P. C; GONÇALVES, A. D. M A: Avaliação do Potencial do Emprego do Biogás nos Equipamentos Utilizados em Sistemas de Produção de Leite. Anais do $3^{\circ}$ Encontro de Energia no Meio Rural. Campinas, SP. 12-15 de setembro de 2000. p.70. 
29 Havlikova, M; C. Kroeze, C; Huijbregts, M.A.J: Environmental and health impact by dairy cattle livestock and manure management in the Czech Republic

Science of The Total Environment, Volume 396, Issues 2-3, 25 June 2008, Pages

30 Instituto de Pesquisas Tecnológicas: Produção de Biogás. São Paulo: IPT, 1982. $27 \mathrm{p}$.

31 Jewell, W.J: Jewell-"Energy , Agriculture and Waste Manangement"-Ann Arbor Science M-E. McCormick-"Ocean Wave Energy Conversion"-John Wiley and Sons, 1981.

32 JUNQUEIRA, R. V. B; ZOCCAL, R; MIRANDA, J.E.C: Análise da sazonalidade da produção de leite no Brasil. In: X Minas Leite. Juiz de Fora-MG. 2008.

33 KALIA, A.K; SINGH, S.P; Horse dung as a partial substitute for cattle dung for operating family size biogas plants in a Hilly region, Biosource Technology, 64 (1998), 63-66

34 KEENAN, M. H: Solute transporte. In: ROSE, A. H. and HARRISON, J.S. (ed.). New York, Academic_Press, Vol. 3 (2nd edition), 1989, p. 5-56

35 KIEHL,E.J: Fertilizantes orgânicos. Agronômicas "Ceres": São Paulo, 1985.

36 Lodman, D.W; Branine, M.E; Carmean, B.R; Zimmerman,P; Ward, G.M; Johnson, D.E: Estimates of methane emissions from manure of U.S. cattle Chemosphere, Volume 26, Issues 1-4, January-February 1993, Pages 189199

37 LUCAS, J.J; SILVA, F. M: Biogás, produção e utilização. Faculdade de Ciências Agrárias e Veterinárias. Jaboticabal, 1987 (s.d.). 8p.

38 MACEDO, J.A.B.: Águas \& Águas. São Paulo: Varela, 2001. 5005 p.

39 MARCELO, P: Levantamento de técnicas de manejo de resíduos da bovinocultura leiteira no estado de São Paulo In: Cone, M. Farms try to clean up their act. Jornal "Los Angeles Times", 28 de abril de 1998.

40 MARTINS, P. C.; GUILHOTO, J. J. M: Geração de Emprego e Renda no Sistema Agroindustrial do Leite Brasileiro. In: PORTUGAL, J. A. B: O Agronegócio do Leite e os Alimentos Lácteos funcionais. Juiz de Fora: EPAMIG - Centro Tecnológico -ILCT, 2001, p. 37-54.

41 MELO, E.P: Esterco liquido- vantagens econômicas e produtivas. Balde Branco, pg. 28 à 30, 1986. 


\section{1 www.mme.gov.br}

42 Münger. A.; Kreuzer. M: Methane emission as determined in contrasting dairy cattle breeds over the reproduction cycle. International Congress Series, Volume 1293, July 2006, Pages 119-122

43 NAVARATNASAMY, M; PAPWORTH, L: Integrating Biogas, Confined Feedlot Operations and Ethanol Production , Agri-facts, December 2007.

44 NETO, A. P: Biodigestor, uma alternativa energética.Gráfica Mundial, João Pessoa-PB, 2006.

45 NOGUEIRA, L.A.H: Biodigestão: a alternativa energética, Ed. Nobel, São Paulo, 1986.

46 PARIKH, S. C; Rothkpf, M. H: Long Run elasticity of US energy demand: a process analysis approach", em Energy Economics, vol.2, pp. 31-36, 1980.

47 PAULO,F; DOMINGUES, H. L: Manejo sanitário animal. Epub, pg. 59 a 75 Rio de janeiro, 2001.

48 PEREIRA, A.S: Higiene e sanidade animal. Santarém, pg. 233, 1992. Pimentel, D; Edwards, C. A: Biosci. 1982, 32, 595.

49 Pimentel, D.; Edwards, C. A.; Biosci. 1982, 32, 595.

49 POTE, D.H.; REED, B.A.; DANIEL, T.C.; NICHOLS, D.J.; MOORE, P.A.; EDWARDS, D.R: Water-quality effects of infiltration rate and manure application rate for soils receiving swine manure. Journal Soil and Water Conservation, v. 56, n. 1, p. 32-37, 2001.

50 POHLMANN, M. Levantamento de técnicas de manejo de resíduos da bovinocultura leiteira no estado de São Paulo In: Cone, M. Farms try to clean up their act. Jornal "Los Angeles Times", 28 de abril de 1998.

50 Prince N.D; Ruihong Z: Treatment of dairy wastewater with two-stage anaerobic sequencing batch reactor systems - thermophilic versus mesophilic operations Bioresource Technology, Volume 68, Issue 3, June 1999, Pages 225-233

51 Rabello, E.G: Estudo de tratamento de drenagem ácida de mina proveniente de um depósito de rejeitos de mineração de carvão. 2006. Monografia- Curso de Engenharia Ambiental, UNESC- Criciúma- SC. 
52 RESENDE, A.P.S. et al: A energia renovável e o meio ambiente. In: Energia, Automação e Instrumentação. XXVIII Congresso Brasileiro de Engenharia Agrícola. Lavras: UFLA. Anexo. p 16, 1998.

53 SACHS, I: Brasil rural: da redescoberta à invenção, in Estudos Avançados, 15 (43) pp. 75-82, 2001.

54 SILVA, F.M: Utilização do biogás como combustível. In: Energia, Automação e Instrumentação. XXVIII Congresso Brasileiro de Engenharia Agrícola. Lavras: UFLA. Anexo. p 97, 1998.

55 SILVEIRA, V. R: Tratamento de efluentes de drenagem ácida de mina de carvão por precipitação e sedimentação. Tese de doutorado em Engenharia. Escola Politécnica da USP. 2004

56 Summers, P. N; Hobson, C. R; Harries, A. J.R: Stirred-tank, mesophilic, anaerobic digestion of fattening-cattle wastes and of whole and separated dairy-cattle wastes Biological Wastes, Volume 20, Issue 1, 1987, Pages 43-62

57 SYLVIE G.R; Morand, P.F; Tran, G: Literature survey of the influence of dietary fat composition on methane production in dairy cattle. Livestock Production Science, Volume 82, Issue 1, July 2003, Pages73-79

58 THOMAS, A; BARBARA, A; VITALIY, K; WERNER, Z; KARL, M; LEONHARD, G: Biogas production from maize and dairy cattle manureInfluence of biomass composition on the methane yield. Agriculture, Ecosystems \& Environment, Volume 118, Issues 1-4, January 2007, Pages 173-182

59 U.S.A; E.P.A: Evaluating ruminant livestock efficiency projects and programs. In: PEER review draft. Washington: Enviromental Protection Agency, 2000. 48p.

60 UNFCCC- UNITED NATIONS FRAMEWORK CONVENTION ON CLIMATE CHANGE - "Convenção sobre Mudança do Clima que trata do MDL” - 2 ed. Brasília: MCT, 2001a, p. 30.

61 VAN, H; WILKIE, H.H; WILKIE, A C; POWERS, W.J; NORDSTEDT, R.A: Components of dairy manure management systems. Journal Dairy Science, v.77(7) p.2008-30, 1994.

62 Wohlt, J.E; Frobish, R.A; Davis, C.L; Bryant, M.P; Mackie, R.I:

Thermophilic methane production from dairy cattle waste. Biological

Wastes, Volume 32, Issue 3, 1990, Pages 193-207 